\title{
Fabrication, Functionalization, and Application of Carbon Nanotube-Reinforced Polymer Composite: An Overview
}

\author{
Norizan Mohd Nurazzi 1,2,*, M.R.M. Asyraf ${ }^{3, *(1)}$, Abdan Khalina 1,*, Norli Abdullah 2,*, \\ Fatimah Athiyah Sabaruddin 1,4 D, Siti Hasnah Kamarudin ${ }^{5}$, So'bah Ahmad ${ }^{5}$, Annie Maria Mahat ${ }^{6}$, \\ Chuan Li Lee ${ }^{1} \mathbb{D}$, H. A. Aisyah ${ }^{1} \mathbb{D}$, Mohd Nor Faiz Norrrahim ${ }^{7} \mathbb{D}$, R. A. Ilyas $^{8} \mathbb{D}$, M. M. Harussani $^{1}$, M. R. Ishak ${ }^{3}$ \\ and S. M. Sapuan ${ }^{1}$
}

Citation: Mohd Nurazzi, N.; Asyraf, M.R.M.; Khalina, A.; Abdullah, N.; Sabaruddin, F.A.; Kamarudin, S.H.; Ahmad, S.; Mahat, A.M.; Lee, C.L.; Aisyah, H.A.; et al. Fabrication, Functionalization, and Application of Carbon Nanotube-Reinforced Polymer Composite: An Overview. Polymers 2021, 13, 1047

https://doi.org/10.3390/ polym13071047

Academic Editor: Ilaria Armentano

Received: 4 March 2021

Accepted: 23 March 2021

Published: 26 March 2021

Publisher's Note: MDPI stays neutral with regard to jurisdictional claims in published maps and institutional affiliations.

Copyright: (c) 2021 by the authors. Licensee MDPI, Basel, Switzerland. This article is an open access article distributed under the terms and conditions of the Creative Commons Attribution (CC BY) license (https:/ / creativecommons.org/licenses/by/ $4.0 /)$.
1 Institute of Tropical Forestry and Forest Products (INTROP), Universiti Putra Malaysia (UPM), UPM Serdang Selangor 43400, Malaysia; atiyah88@gmail.com (F.A.S.); chuanli_91@hotmail.com (C.L.L.);

a.humaira.aisyah@gmail.com (H.A.A.); mmharussani17@gmail.com (M.M.H.); sapuan@upm.edu.my (S.M.S.)

2 Centre for Defence Foundation Studies, Universiti Pertahanan Nasional Malaysia (UPNM), Kem Perdana Sungai Besi, Kuala Lumpur 57000, Malaysia

3 Department of Aerospace Engineering, Universiti Putra Malaysia, UPM Serdang, Selangor 43400, Malaysia; mohdridzwan@upm.edu.my

4 School of Industrial Technology, Universiti Sains Malaysia, Pulau Pinang 11800, Malaysia

5 School of Industrial Technology, Faculty of Applied Sciences, Universiti Teknologi MARA (UiTM), Shah Alam, Selangor 40450, Malaysia; sitihasnahkam@uitm.edu.my (S.H.K.); sobah@uitm.edu.my (S.A.)

6 Centre for Functional Materials and Nanotechnology, Institute of Science, Universiti Teknologi MARA, Shah Alam, Selangor 40450, Malaysia; anniemaria@uitm.edu.my

7 Research Center for Chemical Defence, Universiti Pertahanan Nasional Malaysia (UPNM), Kem Perdana, Sungai Besi, Kuala Lumpur 57000, Malaysia; faiznorrrahim@gmail.com

8 School of Chemical and Energy Engineering, Faculty of Engineering, Universiti Teknologi Malaysia (UTM), Skudai, Johor 81310, Malaysia; ahmadilyas@utm.my

* Correspondence: mohd.nurazzi@gmail.com (N.M.N.); asyrafriz96@gmail.com (M.R.M.A.); khalina@upm.edu.my (A.K.); norli.abdullah@upnm.edu.my (N.A.)

Abstract: A novel class of carbon nanotube (CNT)-based nanomaterials has been surging since 1991 due to their noticeable mechanical and electrical properties, as well as their good electron transport properties. This is evidence that the development of CNT-reinforced polymer composites could contribute in expanding many areas of use, from energy-related devices to structural components. As a promising material with a wide range of applications, their poor solubility in aqueous and organic solvents has hindered the utilizations of CNTs. The current state of research in CNTs-both singlewall carbon nanotubes (SWCNT) and multiwalled carbon nanotube (MWCNT)-reinforced polymer composites - was reviewed in the context of the presently employed covalent and non-covalent functionalization. As such, this overview intends to provide a critical assessment of a surging class of composite materials and unveil the successful development associated with CNT-incorporated polymer composites. The mechanisms related to the mechanical, thermal, and electrical performance of CNT-reinforced polymer composites is also discussed. It is vital to understand how the addition of CNTs in a polymer composite alters the microstructure at the micro- and nano-scale, as well as how these modifications influence overall structural behavior, not only in its as fabricated form but also its functionalization techniques. The technological superiority gained with CNT addition to polymer composites may be advantageous, but scientific values are here to be critically explored for reliable, sustainable, and structural reliability in different industrial needs.

Keywords: carbon nanotubes; SWCNT; MWCNT; polymer composites; covalent functionalization; non-covalent functionalization; CNT nanocomposites

\section{Introduction}

In 1991, the discovery of carbon nanotubes (CNTs) by Sumio Iijima created a global scientific phenomenon in the field of nanotechnology [1]. A CNT is defined as a one-atom 
thick sheet of graphite rolled into a tube with a diameter of one nanometer, which is classified as a single-wall carbon nanotube (SWCNT); if there are additional or multiple graphene tubes around the core of an SWCNT, this is known as a multiwalled carbon nanotube (MWCNT). Diameters are fractions of nanometers and tens of nanometers. Lengths can be up to a number of centimeters, with both their ends normally capped by fullerene-like structures [2]. It is believed that the unique properties of CNTs have opened new era in the material world, especially in the field of conductive polymer and CNT-based nanocomposites. Since then, different kinds of techniques of have been developed for CNT-incorporated polymer matrices with the aim to fabricate new advanced materials with multifunctional properties. Some of these properties were designed to transfer the unique electrical properties associated with CNTs to insulating polymer matrices with the aim of obtaining better conducting polymer composites.

Theoretical and experimental results on CNTs have showed a high modulus of elasticity: greater than $1 \mathrm{TPa}$ (the elastic modulus of diamond is $1.2 \mathrm{TPa}$ ). In addition, CNTs also possess a strength that is 10-100 times higher than the resilient steel at a fraction of the weight [3]. Additionally, CNTs have an excellent thermal stability of up to $2800{ }^{\circ} \mathrm{C}$ in vacuum and an electrical conductivity in the vicinity of $10^{3} \mathrm{~S} / \mathrm{cm}$, with an electriccurrent-carrying capacity that is 1000 times higher and thermal conductivity of about $1900 \mathrm{~W} \mathrm{~m}^{-1} \mathrm{~K}^{-1}$ (which is about twice as high as diamond) [4,5]. SWCNTs in a hexagonal honeycomb structure consist of $\mathrm{sp}^{2}$ hybridized carbon in a that is rolled into a hollow tube morphology, while MWCNTs consist of multiple concentric tubes encircling one another [6]. To date, CNTs have shown increasing interest as potential conductive fillers and reinforcements for polymeric composites. Apart from their high electrical conductivity, CNTs have unique electronic and optical properties for the development of organo-electronic devices [7]. High conductivity can be achieved at a very low concentration of CNTs of between 0.0025 and $4 \mathrm{wt} . \%$, owing to their high aspect ratio (L/D, where $\mathrm{L}$ is length of a CNT and D is diameter of a CNT) from hundreds to 1000. All these superiorities allow CNTs to have tremendous potential for nanotechnology fields, especially for use as composite fillers and reinforcements in order to enhance the mechanical, electrical, and thermal properties of resulting composite systems. Many potential applications for CNTs, including microwave absorption $[8,9]$, corrosion protection $[10,11]$, reinforced materials in natural fiber composites [12,13], electromagnetic interference shielding (EMI) [14,15], batteries [16,17], solar cells [18-21], chemical sensors [22-24], hydrogen storage [25,26], field-emission materials [27,28], and adsorbents [29,30], have been reported.

Besides the aforementioned characteristic of CNTs, the rigidity, chemical inertness, and strong $\pi-\pi$ interactions of pristine CNTs cannot be synthesized and fabricated due to the difficulties of dissolving or dispersing them in common volatile organic solvents or polymeric matrices. Such actions rely on the agglomeration properties of nanotubes while considering the electrostatic interaction and Van der Walls forces of CNTs that impart the low dispersion properties [31]. Furthermore, the physical nature of the nanosized CNTs plays an important role in dispersing them into a polymer matrix, as well as for a polymer to encapsulate onto a CNT surface. It has been proven that these bundles and agglomerates led to the deterioration of the mechanical and electrical properties of composites compared to the theoretical predictions for individual CNTs [32]. In other words, the dispersion of CNTs does not merely depend on the geometrical problem that related to the length and size of the CNTs alone; instead, it involves a technique that separates individual CNTs from highly entangled and agglomerated CNTs and then stabilize the CNTs in a polymer matrix in order to avoid further agglomeration [33]. Thus, the chemical modification of the side walls of the surfaces of CNTs is needed to improve their dispersion or solubility in solvents or polymers, as well as to improve their interaction and reactivity with polymers by hydrogen bonding interaction [34]. 


\section{Synthetization of Carbon Nanotubes}

Various techniques have been reported in the literature for the synthesis of CNTs, namely arc discharge, chemical vapor deposition (CVD), the sol-gel process, laser ablation, and electric arc discharge [35]. In the arc discharge technique, direct current is transmitted through graphite electrodes under inert argon at low pressure. The basic concept of laser ablation is similar to arc discharge. The furnace uses a pulsed laser as a point of heat source to provide heat. When using this technique, high-carbon vapor is released from the graphite. The flowing gas is used to move the carbon vapor and the argon. Meanwhile, in CVD, hydrocarbons are used as precursors in the presence of metal catalysts at temperatures varying from 500 to $1000^{\circ} \mathrm{C}$. The hydrocarbons are decomposed at this temperature and, thus, the development of the CNTs as the system cools. The CVD technique is considered the most commonly employed for the mass production of CNTs. Examples of CVD techniques for the production of CNTs include hot-wire (HWCVD), hot-filament (HFCVD), microwave plasma-enhanced (MWCVD), oxygen-assisted, aerosolassisted (ACVD), and liquid-injection (LICVD) [36]. Table 1 shows the advantages and limitations of some of techniques used in the preparation of CNTs. Being classified as SWCNT and MWCNT, CNTs comprise different chiralities such as arm chair, zig zag, and chiral, all of which affect their structures, properties, and applications [31,37]. Based on reviews, the arm chair chirality has similar properties to metals, while the zig zag and chiral chiralities are more likely to be semiconductors [38]. Additionally, diameter and chiral angle also play important roles in different CNT properties. Therefore, the splendid properties of CNTs may hinder and provide challenges for synthetization techniques.

Table 1. The advantages and limitations on some of the techniques used in the preparation of carbon nanotubes (CNTs). CVD: chemical vapor deposition.

\begin{tabular}{|c|c|c|}
\hline Technique & Advantages & Limitations \\
\hline Arc discharge & $\begin{array}{l}\text { - Arc discharge was based on a high voltage arc to } \\
\text { produce plasma. } \\
\text { Produced higher quality CNTs than thermally produced } \\
\text { CVD materials. }\end{array}$ & 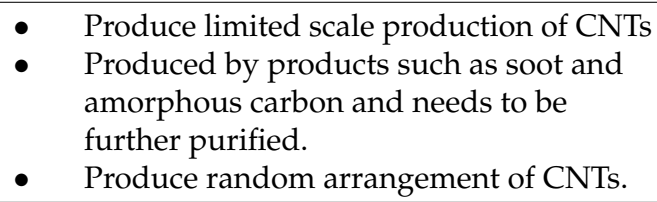 \\
\hline Laser ablation & $\begin{array}{l}\text { - } \quad \text { Produce high-quality CNTs in a large amount. } \\
\text { Laser ablation utilizes a laser to add radiation energy to } \\
\text { the synthesis reaction. }\end{array}$ & $\begin{array}{l}\text { - } \quad \text { High-energy consumption } \\
\text { - Adhering impurities, thus requiring } \\
\text { further purification. }\end{array}$ \\
\hline CVD & $\begin{array}{l}\text { - Produce large scale of CNT production and vertical } \\
\text { alignment of CNTs. } \\
\text { - } \quad \text { Little impurities compared to arch discharge and laser } \\
\text { ablation. } \\
\text { - } \quad \text { Better control of CNT growth. } \\
\text { Simple technique, consumes less energy, and is versatile. }\end{array}$ & $\begin{array}{l}\text { - Higher in CNT relative defectiveness. } \\
\text { - Complex process, difficulty in process } \\
\text { controlling. } \\
\text { - Production of toxic and corrosive gases. }\end{array}$ \\
\hline
\end{tabular}

\section{Functionalization of Carbon Nanotubes}

Modifying the sidewalls of CNTs may affect the solubility characteristic, which can affect the fabrication properties of CNT nanocomposites [39]. Zhao and Stoddard (2009) [40] reported the possibilities of the non-covalent functionalization by small molecules, grafting or wrapping CNTs with polymers in order to improve the electrochemical properties of the material itself. The incorporation of chemically functionalized CNTs into polymers imparts enhancements in mechanical performance because it allows for chemical covalent bonding between CNTs and a polymer matrix. The utilization of chemical functionalization to achieve covalent linkages has been done in SWCNT-reinforced polymer composites [41]. In addition, the use of chemical functionalization is also needed to enhance the nanotubepolymer interface. Such a modification allows for the increases of the interfacial bonding between SWCNTs and the polymer, which leads to improvements in interfacial strength. This improvement enhances the load transfer mechanism of the SWCNTs with the purpose 
of increasing the macroscopic and microscopic mechanical performance of composite systems [38].

Several methods of functionalization are chemical [42], electrochemical [43], mechanochemical [44], and plasma [45] in nature. The functionalization of CNTs is used to functionalize their surfaces and side chains. The most common method of chemical functionalization is the one that uses strong acids to remove the end caps and to shorten the length of CNTs. Additionally, oxide groups-particularly carboxylic acids, carbonyl, and hydroxyl groups-are added to the ends and defect sites of CNTs through acid treatments [46]. Further chemical reactions can be performed on these oxide groups to be functionalized with other groups such as amides and thiols [47,48]. Balasubramanian and Burghard (2005) [49] grouped the covalent functionalization of SWCNTs method into three different approaches, namely thermally activated chemistry, electrochemical modification, and photochemical functionalization.

The interfacial bonding between CNTs and polymer matrixes plays a significant role in the properties enhancement of CNT-reinforced polymer composites. Weak interactions between CNTs and polymer matrixes leads to poor interfacial adhesion and thus to CNT agglomeration and aggregation within the polymer matrix. Consequently, the mechanical, thermal, and electrical performance of the composite is weakened [50]. In light of this, the functionalization of CNTs is a potential way to counter problems arising from the fabrication, interfacial adhesion and interaction between matrixes and other reinforcements. The improvement in the interfacial bonding between CNTs and polymer matrixes can help to develop better interfacial strength and thus improve the load transfer mechanism of the CNT structures [51,52].

CNTs may be modified to functionalize their side-walls and side chains. Treatments using strong acids to remove the end caps and to shorten the length of the CNTs are considered the most common treatments applied to modified the CNTs and are known as chemical functionalization. Chemical functionalization via acid treatment allows for the addition of oxide groups - mainly carboxylic acids, carbonyl, and hydroxyl groupsto the tube ends and defect sites of CNTs (Figure 1(a)). Extended chemical reactions can be performed on these oxide groups to functionalize them with other functional groups such as amides and thiols [47,48]. Functionalization of CNTs by the attachment of suitable functional groups onto their conjugated $\mathrm{sp}^{2}$ carbon scaffold is the requirements for expediting the solubility and ease of dispersion, manipulation, and processibility. In the present section, the current state of functionalization is reviewed, differentiating the covalent and non-covalent functionalization of CNT-reinforced polymer composites (Figure 1) [41,53].

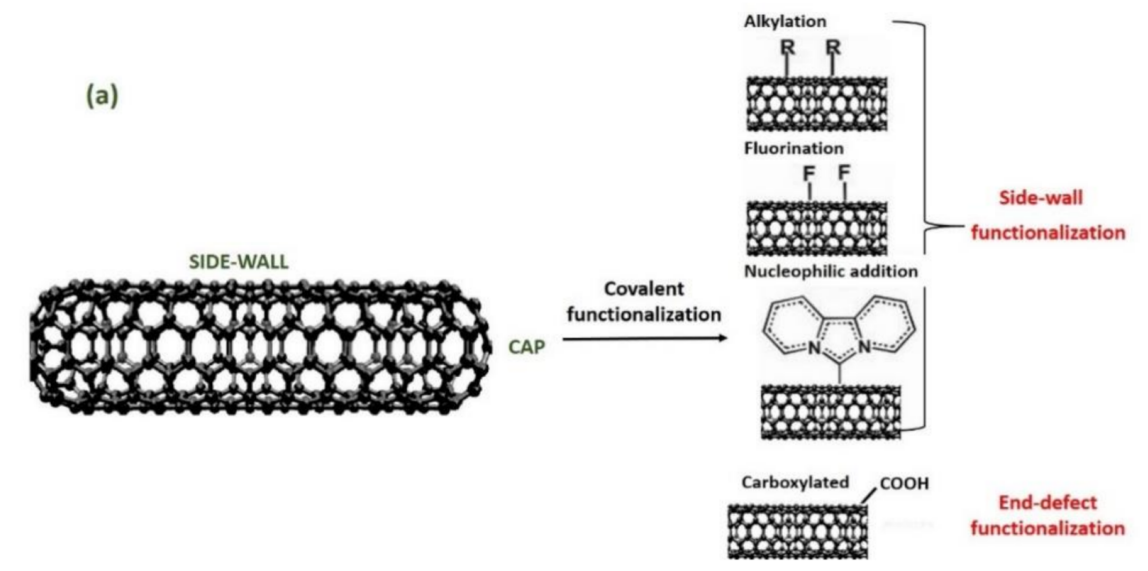

Figure 1. Cont. 
(b)

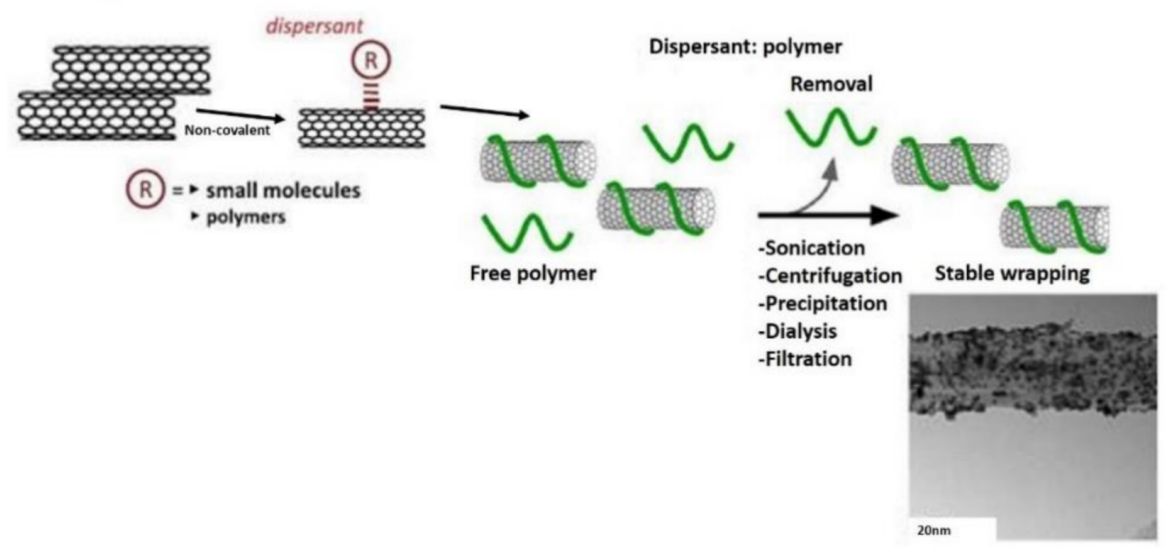

Figure 1. (a) The covalent functionalization phenomena at the side and end-caps of CNT structure (reproduced from [33]) and (b) non-covalent functionalization method for polymer wrapping (adapted from [54]).

\subsection{Covalent Functionalization}

The covalent functionalization of CNTs can be attained by either the direct addition reactions of functional groups to the nanotube sidewalls or through the modification of appropriate surface-bound functional groups on the nanotube ends (Figure 1a) [55,56]. Fundamentally, the method engaged to functionalize CNTs via covalent functionalization is an oxidation process. This reaction allows for the formation of carboxyl groups on the surface of CNTs. However, the structure of a CNT might be affected by the strong oxidizing agent used in covalent functionalization through the changing of a CNT's structure from a strong $\mathrm{sp}^{2}$ hybrid graphite structure to a weak $\mathrm{sp}^{3}$ hybrid carbon structure, thus producing a large number of defects on the CNTs. Despite this, oxidation has become a must in functionalization due to it oxidatively introducing carboxyl groups, which is useful for the next functionalization approach. These carboxyl groups help to produce the covalent coupling of molecules through the creation of amide and ester bonds [57]. Ultimately, there are two categories of acid treatments: one refluxes the nanotubes with a solution of nitric acid [58] and the second exposes the sample to a mixture of sulfuric acid/nitric acid $\left(\mathrm{HNO}_{3} / \mathrm{H}_{2} \mathrm{SO}_{4}\right)$ (1:3 by volume) under high power sonication for a maximum of $6 \mathrm{~h}$ of reaction time [59].

Consequently, the better dispersion of CNTs in a range of polar solvents, including water, can be achieved via functionalization [60]. Plus, the stacking and layering properties of CNTs can be modified through the covalent attachment of functional groups by altering the hydrogen bonding through reduction of the Van der Waals forces between the CNTs. This strongly enables the de-bundling of CNTs into aligned and individual nanotubes [61]. On the other hand, the covalent functionalization enables the improvement of the inherent properties of the CNTs by changing their electrical conductivity and thermal properties. However, there are few CNTs applications that are suitable for covalent modification, so non-covalent functionalization is preferred. Additionally, the carboxyl groups formed on nanotube surfaces are prone to react in the localized defects of functionalized CNTs and suitable reactive organic groups with other chemical chains. Furthermore, the employment of concentrated acid with the combination of a high power sonication can contribute to the deterioration of CNTs by creating a large number of defects in the sidewalls and, even worse, by fragmenting the CNTs into smaller pieces. These defects can result in the severe deterioration of the mechanical, electrical, and thermal properties of CNTs [31].

Referring to work of Jian and Lau (2020) [62], covalent functionalization is one of the most efficient methods to improve load transfer ability by implementing bonded interactions between the CNTs and polymer matrixes. For example, for epoxy-based nanocomposites, covalent attachment on CNTs via epoxy or amine functional groups is 
preferred [63].This attachment via amine $\left(\mathrm{NH}_{2}\right)$ functional groups is attributed to the high reactivity with which they can react with an epoxy matrix to form more than one covalent bond during the cross-linking process. This modification of CNTs, therefore, can lead to the improvement of epoxy nanocomposites compared to nanocomposites with unmodified CNTs [64]. Additionally, chemical treatment also helps to obtain a better dispersion of CNTs in an epoxy matrix, because surface functionalization helps to prevent CNTs from agglomerating and forming bundles. The finding of Zhang et al. (2016) [65] showed that surface functional groups affect the dispersion stability of MWCNTs during the mixing and curing process of the epoxy-amine matrix. The study also compared the chemical mechanism of an epoxy matrix containing $\mathrm{COOH}-\mathrm{MWCNTs}$ that showed re-aggregation during the fabrication process of an epoxy matrix, whereas, the $\mathrm{NH}_{2}$-MWCNTs maintained dispersion stability due to the presence of amine-curing agents that ensured that $\mathrm{NH}_{2-}$ MWCNTs more efficiently participated in the cross-linking reaction with the epoxy matrix.

In a separate study, an acid treatment via a mixture of $\mathrm{H}_{2} \mathrm{SO}_{4} / \mathrm{HNO}_{3}$ and silane functionalization by 3-aminopropyl triethoxysilane was used to improve the dispersion of MWCNTs with an unsaturated polyester matrix [66]. The results showed that the compressive properties of CNT-modified kenaf composite systems were significantly enhanced via the inclusion of the acid treatment and silane. Meanwhile, silane functionalization presented better improvements of the distribution and bonding between the epoxy matrix and the CNTs, which offset the inferiority of the compressive properties of the kenaf composites. As a result, functionalized CNTs contribute to a better performance of kenaf fiber composites via three main factors: (1) the good dispersion of functionalized CNTs in epoxy, (2) better load transfer mechanisms between the epoxy matrix and the CNTs as fillers due to the formation of covalent bonds, and (3) an improvement of the interfacial adhesion between the epoxy matrix and the CNT surfaces.

\subsection{Non-Covalent Functionalization}

Non-covalent functionalization refers to the adsorption of organic or inorganic molecular chains onto CNTs via several means including $\pi-\pi$ stacking, $\mathrm{CH}-\pi$, hydrogen bonding, and electrostatic interaction. Through this functionalization, the structure of CNTs can remain almost unchanged and the initial mechanical properties of CNTs can be effectively preserved. According to Bose et al. (2010), non-covalent functionalization is an efficient option to shape a CNT and polymer interface, as well as to maintain the reliability of the nanotubes. This method is particularly attractive due to its possibility to absorb various ordered structure groups on CNT surfaces without interfering with the extended $\pi$-conjugation of the nanotubes, as well as its ability to create linking with the surface coating/wrapping of low-molecular-weight surfactants (anionic/cationic) [67], polymers [68], liquid crystalline p-conjugated oligomers [69], and amphiphilic cationic polymer molecules [70].

Figure $1 \mathrm{~b}$ shows a schematic diagram of the non-covalent functionalization paths of polymers towards CNTs [54]. Furthermore, the non-covalent functionalization works via enthalpy-driven interactions between the CNT surfaces and the dispersants and/or entropy-driven interactions, e.g., hydrophobic interaction using surfactants [54]. For surfactant dispersion, sodium dodecyl sulfate [71], sodium dodecyl benzene sulfonate [72], sodium cholate [73], cetyltrimethylammonium bromide [74], Brij, Tween, and Triton X [75] have typically been used due to their availability and low cost [76]. However, non-covalent bonding, such as hydrogen bonding and $\pi-\pi$ stacking, is relatively weak in comparison to covalent bonding. The polymer chains or organic molecules attached onto MWCNTs can desorb from MWCNT surfaces when MWCNTs are filtered and re-dispersed or the solvent changes [77].

Several findings on the non-covalent functionalization methods by using functional polymers to wrap onto CNT surfaces have been reported. Results have shown improvements of the mechanical properties of polymer composites [78]. For example, Mandal and Nandl (2012) fabricated nanocomposites using polythiophene (PTh)-wrapped MWCNTs 
via $\pi-\pi$ stacking interactions. After the addition of $0.05 \mathrm{wt} . \%$ of functionalized MWCNTs, the Young's modulus, tensile strength, and fracture toughness of the poly (vinylidene fluoride) (PVDF) composites were two-to-three times higher than those of unfunctionalized MWCNTs.

Cha performed a different study on the dispersion of CNTs in epoxy matrix composites using polystyrene sulfonate (PSS) and poly(4-aminostyrene) (PAS) that attached to the surfaces of CNTs by non-covalent functionalization. In the case of PAS, the amino group chemically bonded with the epoxide groups in the epoxy groups. The non-functionalized CNTs with PSS and PAS showed enhanced mechanical properties when incorporated into the epoxy nanocomposites. This finding proved that when non-covalent functionalized CNTs were incorporated into a modified bisphenol-A type epoxy matrix, it yielded a Young's modulus of $3.89 \mathrm{GPa}$ and a tensile strength of $82.59 \mathrm{MPa}$ with the addition of only 1 wt.\% PAS-CNTs. The mechanical properties of the nanocomposites were improved due to better dispersion and strong affinity of the epoxy matrix imparted from the noncovalent functionalization [79].

The effect of percolation on the electrical conductivity of non-covalently amino molecule-coated MWCNT/epoxy nanocomposites was investigated by Zhang et al. (2012) [80] by attaching the organic amino molecules of a tetrazine compound onto the surfaces of MWCNTs. The amino groups chemically bonded with epoxide groups in the epoxy of MWNT/epoxy nanocomposites and imparted a higher conductivity compared to that of pristine MWCNT/epoxy nanocomposites at a similar MWCNT content. The percolation threshold of the amino coated MWCNT/epoxy nanocomposites was found to be $0.13 \mathrm{wt} . \%$, while that of pristine MWNT/epoxy composites was $0.51 \mathrm{wt} \%$. The lower percolation threshold indicated that the effectiveness of amino group attachment onto the surface of MWCNTs via non-covalent functionalization. This led to a better improvement of the dispersion of the MWCNTs in the epoxy matrix, which is important for MWCNTs to form an electrically conductive network to enhance electrical conductivity.

\section{Fabrication Technique Involved in Carbon Nanotube Polymer Composites}

In practice, there are a variety of techniques to incorporate and fabricate CNTs with a polymer matrix. Several parameters that control the maximization performance of CNTs in polymer composites include the types of fabrication, dispersion, and orientation of CNTs; the length of the CNTs; the matrix; and the chirality. Many attempts have been developed to use CNTs as outstanding nanofillers to strengthen polymer matrixes for CNTreinforced polymer composite production [81]. The effect of nano-scale CNT distribution leads to an exceptionally large surface area within the nanocomposites compared to other carbon-based micron fillers, as depicted in Figure 2.
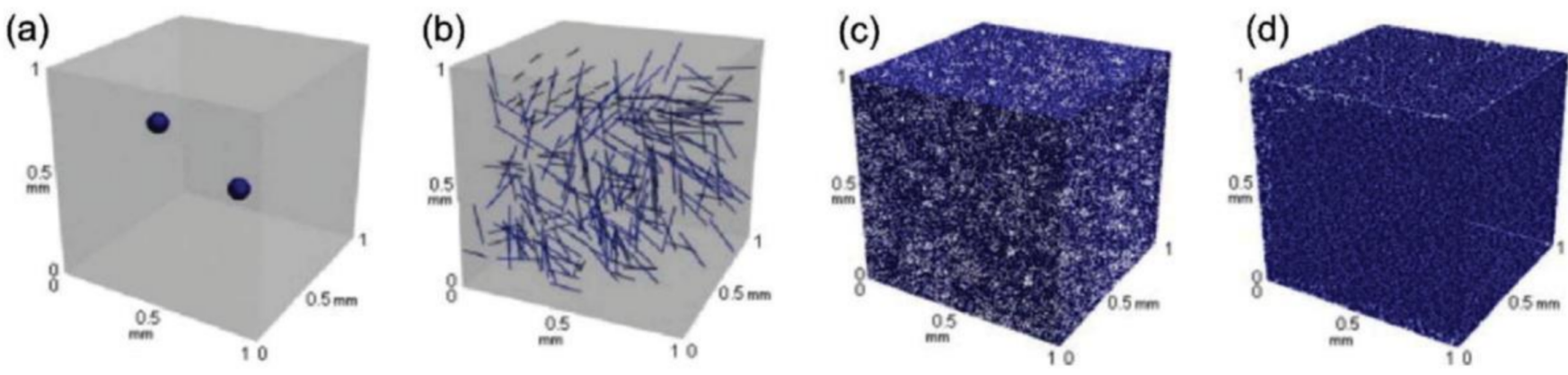

Figure 2. Distribution of micro- and nano-scale fillers: (a) $\mathrm{Al}_{2} \mathrm{O}_{3}$ particle, (b) carbon fiber, (c) graphene nano-platelets (GNPs), and (d) CNTs. Adapted from [82]. 


\subsection{Melt Mixing}

Melt mixing is an industrial-friendly process for the production of thermoplasticbased nanocomposites. This method was recommended because it is fast, inexpensive, and suitable for insoluble polymers (particularly thermoplastics that cannot be processed in common solvents). Generally, this technique involves the blending of polymer matrixes with CNTs, which are then subject to shear forces at elevated temperatures using a Banbury mixer or an extruder machine that contributes to the disruption and dispersion of CNT bundles in a polymer matrix. Less viscous thermoplastics ease the blending process with nanotube bundles as the temperature increases $[81,83,84]$. This requires no solvents/chemicals, supports a high volume of bulk polymers, and has a low cost with the least effects on the environment, thus making this technique the best choice to fabricate CNT-based nanocomposites [5]. The process generally involves the blending of polymers with CNTs, usually at high filler contents continuously or in the form of batches at a certain level of temperature when using a extruder or a high shear mixer (Figure 3), respectively. A high shear mixer is often used to prepare master-batches of nanocomposites that are highly concentrated with the desired amount of CNTs loaded in the nanocomposites. However, the use of high shear force and temperature might break the CNTs and polymer chains $[81,82]$.

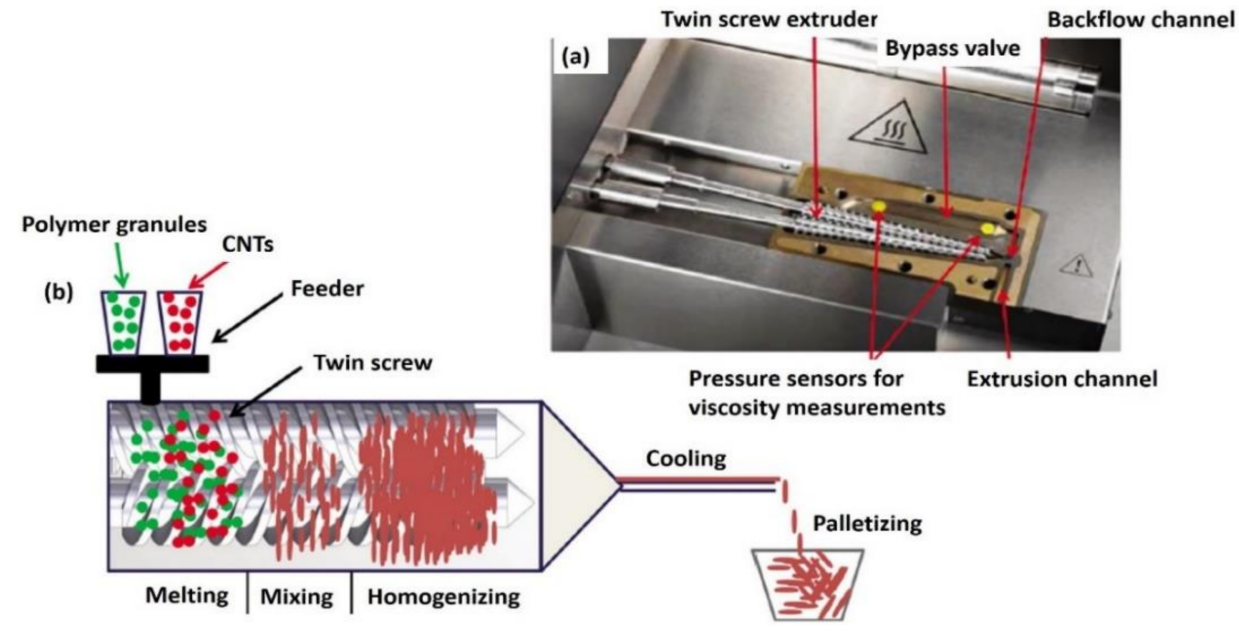

Figure 3. (a) View of micro-compounder with different valves and channels; (b) the schematic representation of a twin-screw extruder for the melt mixing of CNT-reinforced nanocomposites. Adapted from [81,85].

\subsection{Solution Mixing}

Solution mixing is the most common technique to form CNT-based polymer nanocomposites. This techniques involves intensive agitation (e.g., refluxing, mechanical/magnetic stirring, vigorous shaking, high shear homogenization, and bath/probe sonication) to rigorously aid the mixing of CNTs with polymers in a solvent with the aim to facilitate nanotube de-bundling and their dispersion inside a host polymer matrix $[37,86]$. This method is able to fabricate nanocomposites without losing the properties of the nanoparticle, as the dispersion and interfacial bonding of the filler are very important to impart good mechanical and electrical properties. Numerous studies on the formation of CNT-based nanocomposites have been carried out with this method (using both organic and aqueous media, as well as a variety of polymer matrices) $[37,87,88]$. CNTs are dispersed into a suitable solvent by stirring, mixing, or sonication while applying mechanical energy to unbundle the CNTs. The dispersed CNTs are then mixed with a polymer, followed by a controlled evaporation process. Finally, the dispersed CNTs and polymer matrix are mixed and form a composite film [89]. 
The choice of solvent is very important, as it depends on the solubility of the polymer matrix. The solvents for CNTs and a polymer matrix may be the same or different, but they must have good miscibility. Additionally, the boiling point of the solvent has been found to have a remarkable influence on the properties of formed nanocomposites. Low-boiling point solvents are generally preferred because they are easily removed from the mass of solution-made nanocomposites. On the other hand, high-boiling point solvents are difficult to be removed and tend to get trapped in the solidifying/curing mass. The trapped solvent may obstruct the curing reaction (in thermosets) or can act as a softener (in thermoplastics), thereby deteriorating the electrical, thermal, or mechanical properties [90]. Therefore, surfactants can be applied for tube dispersion or physically/chemically functional CNTs can be used in order to improve dispersion and to solve the problem of tube shortening after high-power agitation [91-93]. Nevertheless, solution processing is still broadly used and is one of the key steps in the formation of thermosetting-reinforced nanocomposites.

\subsection{Sonication}

Sonication is widely used for dispersing CNTs in solutions, for functionalizing CNTs, and for formulating nanocomposites and nanomaterials [94,95]. In physical surface treatment, CNTs are dispersed in a solvent solution with the aid of dispersants and ultrasound before the addition of a polymer matrix like epoxy resin. During sonication, while the CNT bundles break down into individual CNTs, the dispersing molecules adsorb to the surface of the CNTs. Several factors, including the level of sonication treatment, the CNT geometry, type of dispersant had influenced an optimum dispersion of CNTs in solvent solutions and thus the efficiency of CNTs on the final composite structure. In other research, CNTs have been treated in a copolymer-ethanol solution to promote dispersion in the solvent and, consequently, in the epoxy resin. The process of mixing and dispersing CNTs in solvents and the manufacturing of CNT-epoxy composites is shown in Figure 4.

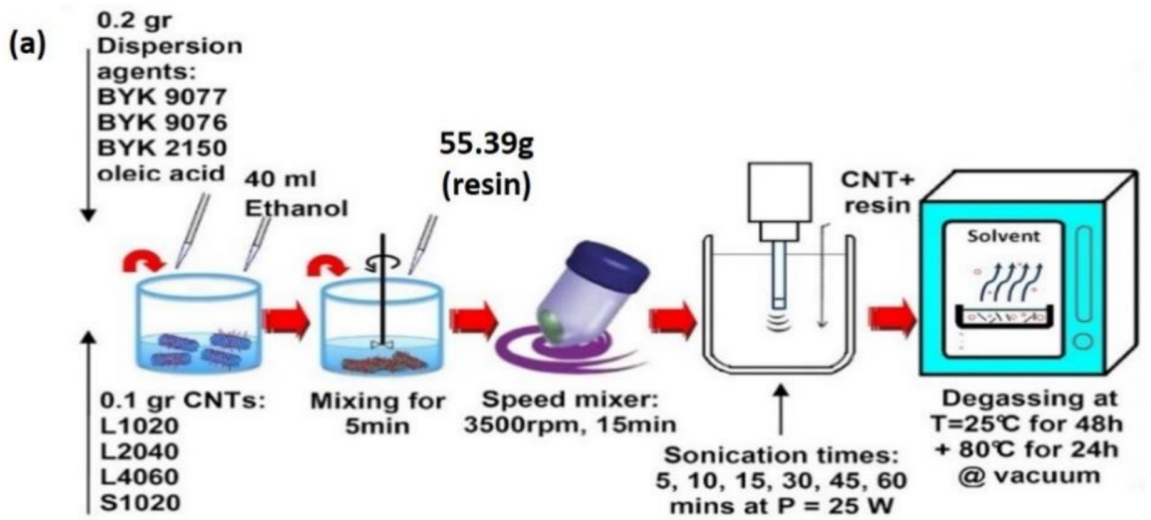

44.31g

(b) (Hardener)

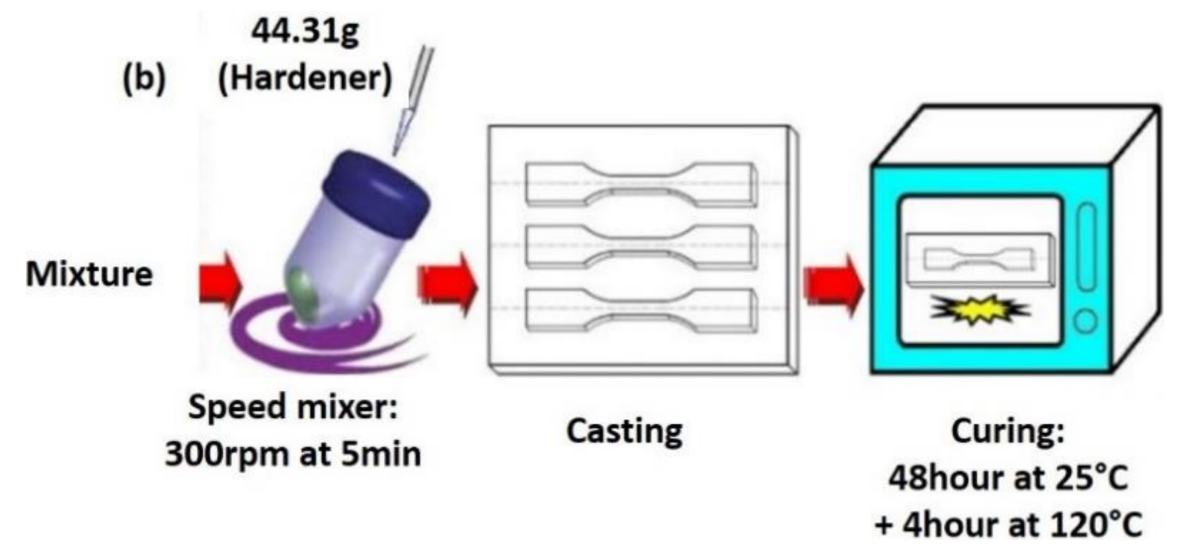

Figure 4. Schematic diagram of the fabrication process for the CNT-epoxy composites: (a) preparation of CNT suspension and (b) preparation of CNT-epoxy composite. Adapted from [96]. 
The energy level can be related to the threshold energy attributed to the sonication time and amplitude that yield the most optimized dispersion of CNTs and performance of composites. A lower concentration gives a higher threshold energy level [95]. However, a too strong sonication treatment can affect the rheological behavior of CNT-based composites, as an excessive sonication time can lead to the reduction of the nanoparticle aspect ratio, which counteracts the formation of a percolation network within the polymer matrix. According to Arrigo et al. (2018) [94], the reduction of the aspect ratio of CNTs can affect the thermo-oxidative resistance of nanocomposites, thus resulting in the deterioration of the long-term stability of the nanocomposites.

\subsection{Resin Transfer Molding}

Resin transfer molding (RTM) is another technique that can be applied to several types of CNTs with low-viscosity thermosetting polymers, and it can produce polymer composites with large sizes and complex shapes within a short cycle time and at a low cost. RTM allows for the manufacturing of versatile structures carried out in a closed system. Super-MWCNT arrays were synthesized with iron as the catalyst and acetylene as the precursor in a silicon wafer with a low-pressure chemical vapor deposition system [97]. From super-aligned arrays, CNTs were drawn and joined end-to-end by Van der Waals forces to create a continuous and aligned CNT sheet. To make a CNT preform, CNT sheets were stacked together at various orientations (Figure 5). The CNT preform was inserted into the resin transfer mold. The sealed resin transfer molding mold was injected with liquid epoxy resin and fully infiltrated the CNT preform in a vacuum oven. The oven temperature was then increased to cure the epoxy, forming a CNT/epoxy composite aligned with a solid-state. The resin transfer mold was then cooled down to room temperature, and the resin transfer mold was released from the CNT/epoxy composite sample. Composites may vary with the use of different CNT preforms and resin transfer molds [98].

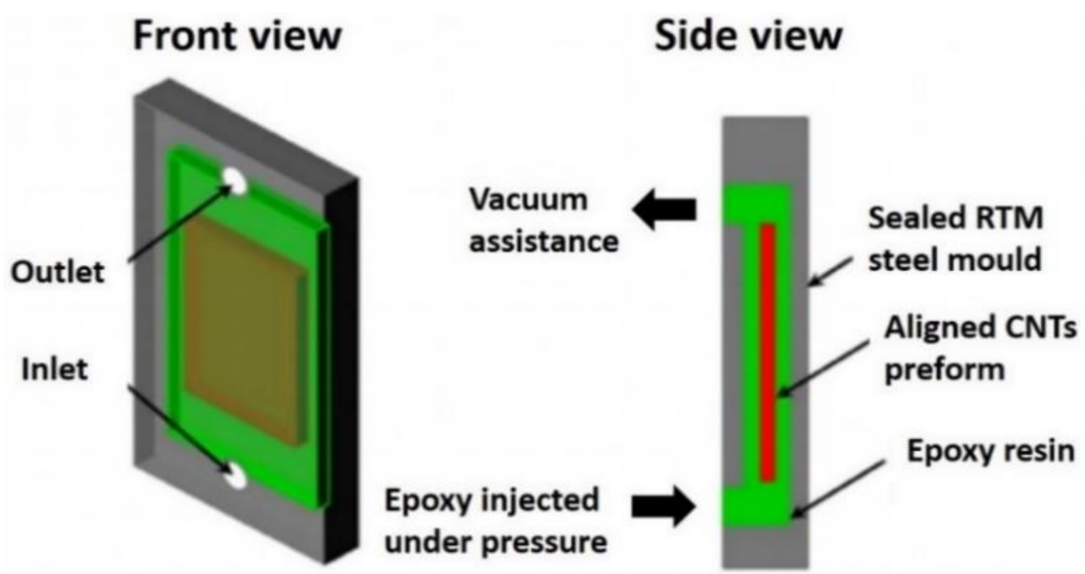

Figure 5. Schematic of the resin transfer molding process for fabricating CNT/epoxy composites. Adapted from [99].

\subsection{Bucky Paper Resin Infiltration}

Bucky paper offers a wide range of features that are capable of reinforcing existing multifunctional applications or invented new ones. Through this method, epoxy resin can be enhanced to become a high performance materials comparable to that glass fiber/epoxy composites with various properties including electrical insulation, semiconduction, thermal insulation, and thermal conduction [100]. An approach to making bucky paper-based phenolic resin composites was reported by Teotia et al. (2014) [101]. Firstly, CNTs were dispersed into a solvent and added to the dissolved phenolic resin. The suspension was then mixed using a high-speed homogenizer to disperse the CNTs in the phenolic resin mixture. The mixture was then filtered with a specially designed filtration system, and a film of CNT-impregnated polymer resin was obtained before being dried to get a 
CNT-phenolic resin prepreg. The prepreg was compression-molded using a hydraulic press. Since prepregs have become the main raw materials in the composites industry, this technique can be applied in composites science and technology for new materials with a combination of tailored mechanical, electrical, and thermal properties [100,101].

\subsection{Aligned CNT Sheet Process}

High volume fraction CNT composites based on aligned CNT sheets have aroused great interest because they are envisioned for advanced composite materials for demanding applications [102-106]. However, achieving high volume fractions of dispersed CNTs in polymers is challenging due to the high viscosity that complicates further processing. Great efforts have recently been made to synthesize millimeter-scale aligned CNT arrays for the production of large-scale CNT structures. The aligned CNT sheets created by the solid-state drawing technique are lightweight and flexible [107]. The vertically aligned CNT arrays are self-directed, highly removable, and rotatable. Therefore, CNT webs are readily removed from arrays and wound to produce horizontally long-aligned CNT sheets on a rotating spool (Figure 6). For the manufacture of high-performance structural CNT composites, the press-drawing technique is effective in producing superior CNT sheets with the high alignment and dense packaging of CNTs [106]. However, the fabricated CNT sheet composites with aligned CNTs leads to limited improvement in electrical conductivity [108].

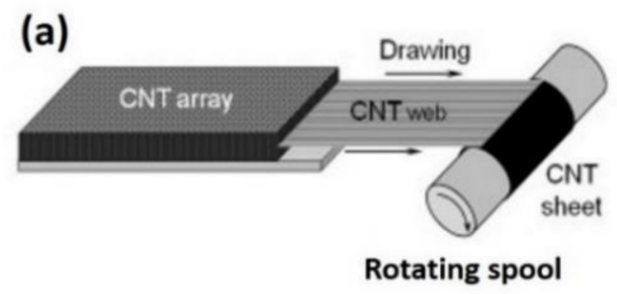

(c)
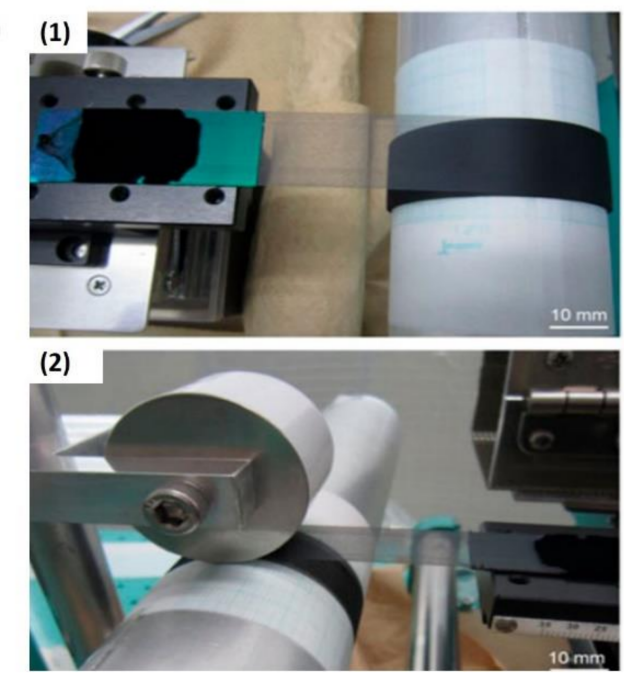

(b)
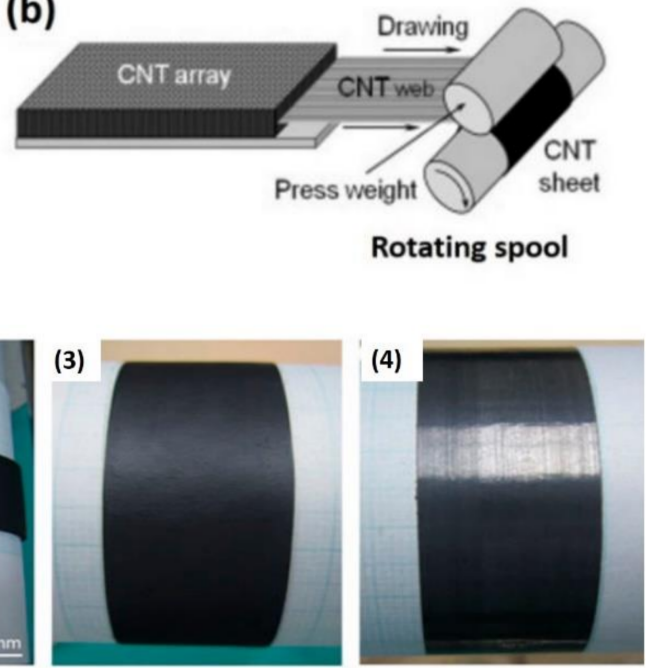

(5)
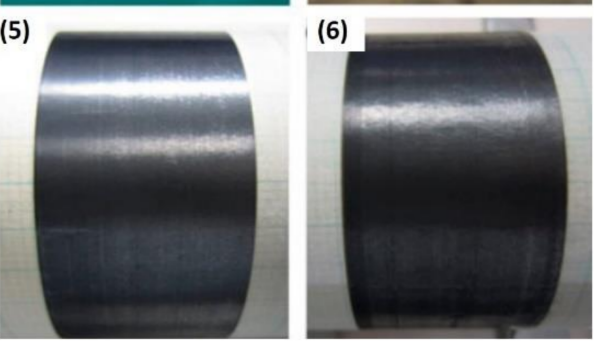

Figure 6. Schematic diagram showing aligned CNT sheet processing: (a) drawing and winding; (b) drawing, winding, and pressing (reproduced from [108]). (c) CNT sheet processing: (1) drawing and winding technique; (2) drawing, winding, and pressing process; (3) non-pressed CNT sheet; and (4-6) pressed CNT sheets under corresponding press load. Reproduced from [107].

\subsection{Shear Mixing}

Shear mixing has been most commonly used for thermoset polymers, e.g., epoxy resins. The calendaring process has been used in this technique. Three-roll milling is a general type of calendaring where the material is forced in between the rotating rollers, which inevitably 
mix it under a high shear force $[109,110]$. Compared to pure epoxy resin, graphene nanoplatelet (GNP)/epoxy composites fabricated through the calendaring process have shown improved density, glass transition temperature, and thermal properties [32]. The three roller mill method and sonication combined with the high-speed scissor mixing technique to reinforce GNPs into epoxy matrixes has been conducted, as shown in Figure 7 [111].

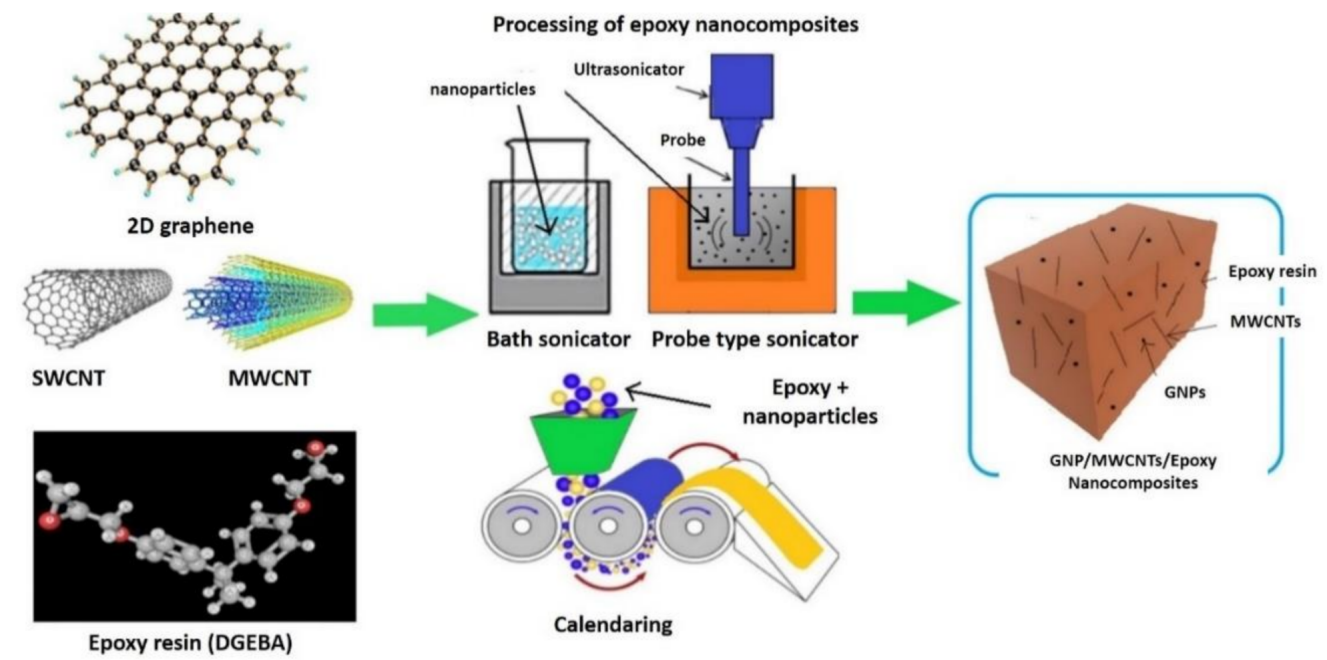

Figure 7. Schematic diagram for the shear mixing technique. Reproduced from [32].

\subsection{In-Situ Polymerization}

To solve the aforementioned dispersion issues between CNTs and polymers, it has been proposed to manufacture CNT composites via in-situ polymerization, especially for polymers that are insoluble, thermally unstable, and cannot be prepared by solution or melt processing [112]. This process is based on the dispersion of CNTs into a monomer matrix with or without the presence of a solvent, where a standard method of polymerization is then performed [113]. The advantage of this technique is that dispersion can be improved if the CNTs are provided with functional groups compatible with the monomer [113,114]. However, during synthesis, an insulating polymer layer is formed on the CNT surfaces, thus hindering the tunnelling mechanism within the composite [115]. As such, the strain sensitivity could also be negatively affected by the formation of a tunnelling barrier during in-situ polymerization [89].

In addition, in-situ polymerization is also used as a hybrid filler for nanocomposites for the physical functionalization of CNTs (through surface polymer wrapping). For the preparation of composites based on insoluble or thermally unstable matrix polymers, in situ polymerization remains the only possible option for materials that cannot be processed through the solution or melt processing routes. However, it is also used in other cases (where the above-mentioned limitations are not applicable) due to the superiority of in situ polymerization in terms of the ability to process high CNT-loading nanocomposites, to facilitate the good dispersion of CNTs within a polymer matrix, and to ensure excellent intimacy between CNTs and matrix polymers [90].

This process requires the dispersion of monomer CNTs (Figure 8), followed by in situ polymerization and leading to CNT/polymer nanocomposite formation. To enhance the distribution of the nanotubes in the monomer and, consequently, in the formed nanocomposites, the exploitation of functionalized CNTs or the use of monomer-grafted CNTs has been achieved. This has resulted in a stronger and more active nanotube-polymer interface that is central to the performance of nanocomposites for structural, electronic, electromagnetic, and electrochemical applications. Table 2 shows a summary of advantages and limitations of fabrication techniques for CNT-reinforced polymer composites. 


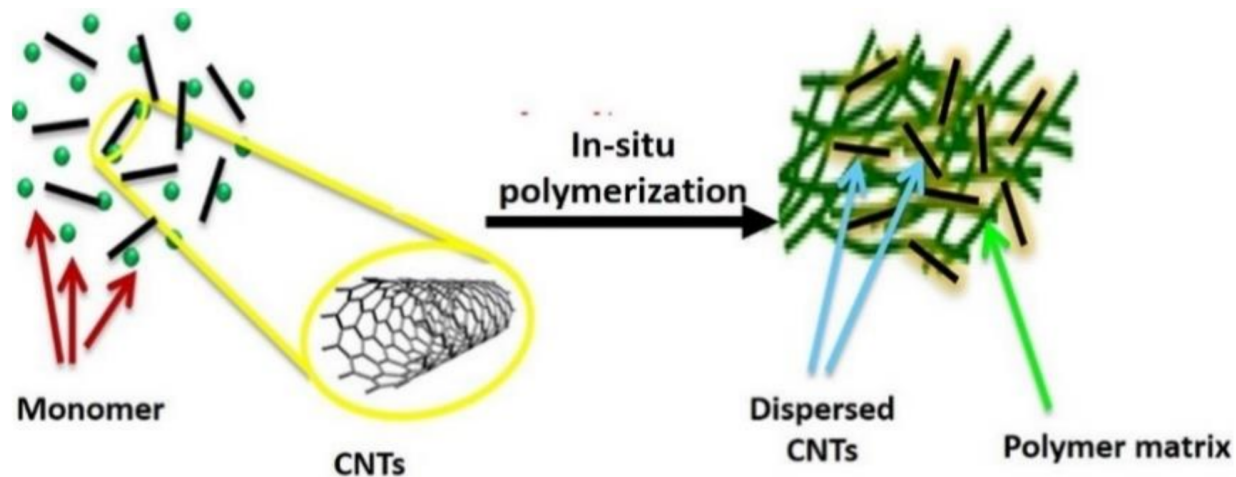

Figure 8. Schematic representation of in situ polymerization process. Reproduced from [90].

Table 2. Summary of advantages and limitations of fabrication techniques for CNT-reinforced polymer composites.

\begin{tabular}{|c|c|c|c|}
\hline Technique & Advantages & Limitations & Reference \\
\hline Melt mixing & $\begin{array}{l}\text { - Able to use for large scales industrial } \\
\text { applications } \\
\text { - } \quad \text { Available for all thermoplastic } \\
\text { materials }\end{array}$ & $\begin{array}{l}\text { - Mixing processes able to damage the } \\
\text { length of nanotubes }\end{array}$ & {$[116,117]$} \\
\hline Solution mixing & $\begin{array}{l}\text { - } \quad \text { Produces tougher material } \\
\text { - } \quad \text { Low electrical percolation threshold } \\
\text { - Homogeneous dispersion of CNTs }\end{array}$ & $\begin{array}{ll}\text { - } & \text { Limited to polymers that are soluble } \\
\text { in solvents } \\
\text { - } & \text { More brittle samples } \\
\text { - } & \text { Non-uniform and inferior properties } \\
\text { - } & \text { Low surface density of CNTs } \\
\text { - } & \text { Limited applications }\end{array}$ & {$[37,86,118-120]$} \\
\hline Sonication & $\begin{array}{l}\text { - } \quad \text { Enhancing the dispersion of CNTs } \\
\text { - Improves the mechanical properties }\end{array}$ & $\begin{array}{l}\text { Breakage of CNTs causes the problem } \\
\text { of mixing-induced fracture } \\
\text { - } \quad \text { High-power and long sonication time } \\
\text { reduce the aspect ratio of CNT } \\
\text { - } \quad \text { Deterioration in properties }\end{array}$ & $\begin{array}{c}{[90,94,116,118} \\
121,122]\end{array}$ \\
\hline $\begin{array}{l}\text { Resin transfer } \\
\text { molding }\end{array}$ & $\begin{array}{l}\text { - } \quad \text { Cost-effective } \\
\text { - } \quad \text { High production rate } \\
\text { - } \quad \text { Ideal for the production of complex } \\
\text { shapes dissipation. } \\
\text { - } \quad \text { Homogenous dispersion } \\
\text { - } \quad \text { Unable to achieve the high loading } \\
\text { - } \quad \text { Smo controllable orientation of CNTs } \\
\text { - } \quad \text { Possibility for gelcoat on both sides } \\
\text { - Tolerance-stable work pieces }\end{array}$ & $\begin{array}{l}\text { Effect of edge flow } \\
\text { - The smoothness and uniformity of the } \\
\text { flow pattern can be disrupted } \\
\text { Defects during the filling of the mold } \\
\text { cavity } \\
\text { Resin velocity may vary from point to } \\
\text { point due to non-uniformity and } \\
\text { rough fiber structure } \\
\text { Formation of voids }\end{array}$ & [99] \\
\hline $\begin{array}{l}\text { Bucky paper } \\
\text { resin infiltration }\end{array}$ & $\begin{array}{l}\text { - Simple way to create polymer } \\
\text { nanocomposites with a high loading } \\
\text { of CNTs } \\
\text { Improves mechanical and electrical } \\
\text { properties }\end{array}$ & $\begin{array}{l}\text { - High viscosity causes problems of } \\
\text { dispersion } \\
\text { - Difficult to accomplish the complete } \\
\text { impregnation of epoxy resin in bucky } \\
\text { paper }\end{array}$ & {$[81,123-125]$} \\
\hline $\begin{array}{l}\text { Aligned CNT } \\
\text { sheet processing }\end{array}$ & $\begin{array}{l}\text { - High volume fraction composites } \\
\text { with desirable structural } \\
\text { characteristics can be produced } \\
\text { Effective in creating superior CNT } \\
\text { sheets with high alignment and dense, } \\
\text { high-performance structural } \\
\text { composites }\end{array}$ & $\begin{array}{l}\text { - The mechanical properties of the } \\
\text { composites may be degraded by the } \\
\text { waviness and poor packing of CNTs } \\
\text { in the sheets } \\
\text { - Hard to handle and to perform } \\
\text { mechanical stretching }\end{array}$ & $\begin{array}{c}{[102,107,126-} \\
128]\end{array}$ \\
\hline
\end{tabular}


Table 2. Cont.

\begin{tabular}{|c|c|c|c|}
\hline Technique & Advantages & Limitations & Reference \\
\hline Shear Mixing & $\begin{array}{l}\text { - } \\
\text { - } \\
\text { Able to separate the aggregates apart } \\
\text { from each other } \\
\text { - } \quad \text { Great technique for dispersion } \\
\text { Effectively separates the CNTs } \\
\text { without causing filament damage } \\
\text { A three-roll mill -prepared epoxy } \\
\text { composites have higher electrical } \\
\text { conductivity }\end{array}$ & 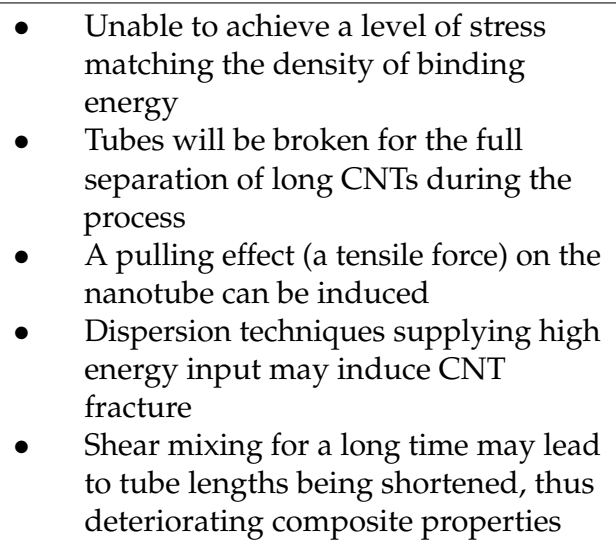 & {$[32,90]$} \\
\hline $\begin{array}{c}\text { In-situ } \\
\text { polymerization }\end{array}$ & 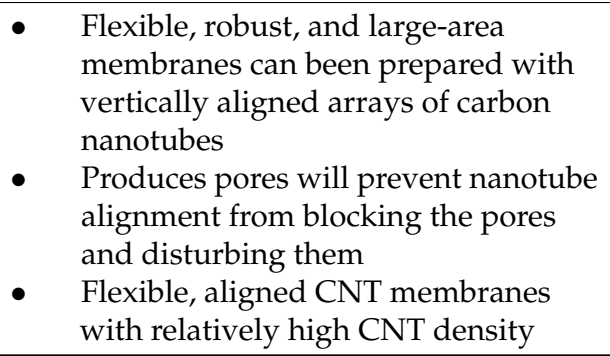 & $\begin{array}{ll}\text { - } & \text { Poor CNT alignment } \\
\text { - } & \text { Increases viscosity along with } \\
\text { progress }\end{array}$ & $\begin{array}{c}{[110,117,129-} \\
131]\end{array}$ \\
\hline
\end{tabular}

\section{Performance of Carbon Nanotube-Polymer Composites}

Indeed, novel processing methods utilizing CNTs as potential composite fillers have improved the mechanical, thermal, and electrical properties of the resulting polymer composites [132,133]. Based on a report by Lourie and Wagner (1998) [134], one can observe that the mechanical properties of CNTs are dependent on the $\mathrm{sp}^{2}$ strength of the C$\mathrm{C}$ bonds of the nanotubes, which makes CNTs good candidates as reinforcement fibers for matrixes. Interestingly, these types of bonding are even stronger than $\mathrm{sp}^{3}$ bonds found in diamonds. The carbon atom in a nanotube forms a planar honeycomb lattice, which is great at forming covalent bonds with other elements due to its electronegativity property. This electronegativity property is a crucial factor for the measurement of how strongly an atom holds onto the electrons orbiting around it. Because of their electronegativity properties, CNTs are expected to be strong enough to form stable covalent bonds to three neighboring atoms with various numbers of elements. It is theoretically known that the value of Young's modulus for CNTs is around $1 \mathrm{TPa}$, which is approximately five times higher than that of steel $[135,136]$, and the tensile strength varies from 11 to $63 \mathrm{GPa}$, which is around 50 times higher than steel $[137,138]$; both of these properties make them the strongest materials ever made by mankind. A comparison of mechanical properties between common structural materials like steel, aluminum, and different fibers is shown in Table $3[139,140]$. 
Table 3. Typical mechanical properties of CNT with other common structural materials. SWCNT: single-walled carbon nanotube; MWCTN: multiwalled carbon nanotube.

\begin{tabular}{ccc}
\hline Type of CNT & Young's Modulus (TPa) & Tensile Strength (GPa) \\
\hline SWCNT & $0.65-5.5$ & 126 \\
\hline MWCNT & $0.2-1.0$ & $>63(300)$ \\
\hline Stainless steel & $0.186-0.214$ & $0.38-1.55$ \\
\hline Kevlar & $0.06-0.18$ & $3.6-3.8$ \\
\hline Diamond & 1.22 & $>60(225)$ \\
\hline Aluminum & 71 & 0.65 \\
\hline Glass Fibers & 72 & 3 \\
\hline Carbon Fibers & 300 & 3 \\
\hline Silicon Carbide Fibers & 450 & 10 \\
\hline
\end{tabular}

In addition to their mechanical properties, CNTs also have good chemical and environmental stability, as well as a high thermal conductivity of about $3500 \mathrm{~W} / \mathrm{m} / \mathrm{K}$ (which is comparable to diamond) [140]. This pronounced combination performance, coupled with the lightness of CNTs, gives them great potential to be applied in highly structural applications such as aerospace. Jiang et al. (2014) [104] studied the fabrication of CNTs with polyimide as the matrix in a unidirectional CNTs composite. When CNTs were incorporated into the polyimide, the modulus and strength of the composite increased by 12 times (nearly three times over pure polyimide), while, at the same time, the value of its electrical conductivity was multiplied by 10 times over pure polyimide. Furthermore, this CNT-reinforced polymer composite had an excellent thermal conductivity value with an increment of 600 times over pure polyimide, which is beyond what was achieved in a previous study. Table 4 shows a comparison of the mechanical, thermal, and electrical properties between pure polyimide and a CNT/polyimide composite [104].

Table 4. Mechanical, electrical, and thermal properties of pure polyimide and a CNT/polyimide composite.

\begin{tabular}{ccccc}
\hline Sample & $\begin{array}{c}\text { Tensile } \\
\text { Strength (MPa) }\end{array}$ & $\begin{array}{c}\text { Elastic Modulus } \\
\mathbf{( G P a )}\end{array}$ & $\begin{array}{c}\text { Thermal } \\
\text { Conductivity } \\
\mathbf{( W / m K - 1 )}\end{array}$ & $\begin{array}{c}\text { Electrical } \\
\text { Conductivity } \\
\left(\mathbf{S c m}^{-\mathbf{1}} \mathbf{)}\right.\end{array}$ \\
\hline $\begin{array}{c}\text { Pristine } \\
\text { polyimide }\end{array}$ & 227.70 & 4.04 & 0.027 & $10^{-16}$ \\
\hline $\mathrm{CNT} /$ polyimide & 680 & 53.73 & 18.4 & 183.3 \\
\hline
\end{tabular}

The dispersion of CNTs into the polyimide matrix was further investigated by means of microscopy. Figure 9 shows SEM micrographs of the tensile fracture surface of a $\mathrm{CNT}$ / polyimide composite. It can be observed that the composite was compact, probably due to the hot pressing and spray winding process. With the addition of CNTs, an interaction enhancement can be seen from the CNT/polyimide composite, which showed an improvement in uniform dispersion due to layer-by-layer winding. 


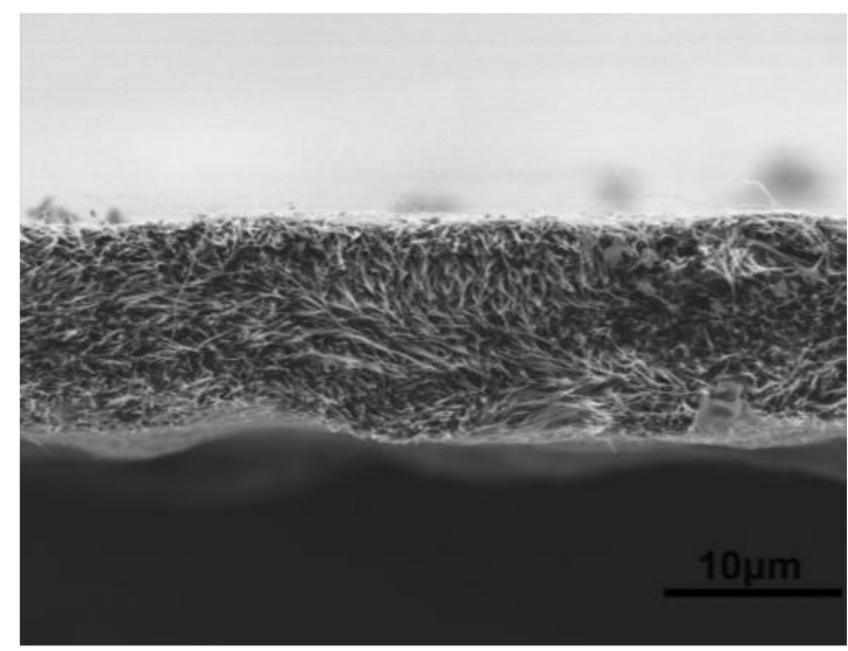

Figure 9. SEM micrographs of tensile fracture surface of CNT/polyimide composite. Reproduced from [104].

Similarly, research conducted by Gardea and Lagoudas (2014) [141] on CNT/epoxy composites reported that the addition of CNTs into epoxy increased thermal conductivity up to $5.5 \%$, and electrical conductivity improved by 10 orders of magnitude compared to pristine CNT/epoxy composites. Sankar et al. (2016) [142] observed an increment for tensile strength and Young's modulus of 0.35 and $1.2 \mathrm{MPa}$, respectively, with the addition of $0.3 \mathrm{~g}$ of MWCNTs into an epoxy composite. Even with a small-quantity addition to polymeric composites, CNTs brought a positive contribution to the properties of mechanical strength and Young's modulus compared with other high-performance synthetic fibers such as carbon fiber and Kevlar [143]. This was due to the better strength and adhesion achieved from long CNT length, the high level of CNT alignment, the good dispersion of CNTs in the polymer matrix, and the high CNT volume fraction [104].

In CNT/polymer composites, the properties of composites are greatly affected by the nature of bonding at the interface, the strength of the interface, and the mechanical load transfer from the surrounding matrix to nanotubes. The literature has also reported that the mechanism of interfacial load transfer from the matrix to nanotubes can be divided into two categories: the weak Van der Waals force between the polymer matrix and the CNT reinforcement [144]. In order to achieve a better physical and mechanical properties of CNT composites, the load stress must be effectively transferred from the matrix to the CNTs. Another factor that brings significant influence on the performance of CNT/polymer composites is the dispersion of CNTs in the polymer matrix through physical and chemical modifications [145].

Basically, the process of micro cracking takes place during curing or in-service at the fiber and matrix interface. Brittle resin systems are susceptible to micro cracking, especially at high processing temperatures and low service temperatures if there is a large difference of thermal expansion between the polymer matrix and the CNT reinforcements. Therefore, the existence of CNTs as a toughening reinforcement to a polymer resin matrix helps in preventing micro-cracking, though the performance at elevated temperatures is compromised at the same time [146]. However, limitations such as the agglomeration of CNTs often occurs due to the hydrophobic surface regions of the corresponding micelles surrounding the nanotubes. Therefore, a thorough understanding of the factors affecting the mechanical, thermal, and electrical properties of CNT-polymer composites has been an important focus of attention.

\subsection{CNT-Reinforced Polymer Composites on Mechanical Performance}

The CNT aspect ratio is a crucial factor in the longitudinal elastic modulus. Generally, CNT have a high aspect ratio, but their ultimate performance in a polymer composite 
is depends on the type of polymer matrix used. The effect of aspect ratio of CNT reinforcement on the Young's modulus and yield strength was investigated in detail by Arash et al. (2014) [147]. According to their study regarding the effect of aspect ratio of CNTs on the mechanical properties of CNT/polymethyl methacrylate (PMMA), there was an increase on the Young's modulus of PMMA polymer reinforced by CNTs, along with an increase of aspect ratio of CNTs; see Table 5. The diameter of the $(5,5)$ CNT reinforcements was $0.68 \mathrm{~nm}$, and their length-to-diameter ratio $(\mathrm{L} / \mathrm{d})$ varied from 7.23 to $\infty$. Ultimately, a higher value of the aspect ratio of CNT increased the stress transfer between the CNTs and the polymer, which in turns led to the high strength and stiffness value of the CNT-polymer composites. It was found that the higher the aspect ratio of CNT, the higher the stress transfers from the polymer matrix to the dispersed CNT [148]. Thus, when there is a large enough aspect ratio of the reinforcement of CNT, there is an adequate load transfer through interfacial shear stress and the full strength of CNT can consequently be used.

Table 5. Young's modulus of polymethyl methacrylate (PMMA) reinforced with $(5,5)$ CNTs.

\begin{tabular}{cc}
\hline Aspect Ratio of CNT (L/d) & Young's Modulus (MPa) \\
\hline 7.23 & 3.90 \\
\hline 14.21 & 4.73 \\
\hline 22.01 & 6.85 \\
\hline$\infty$ & 46.73 \\
\hline
\end{tabular}

Homogeneous dispersion is desirable because it enables uniform load distribution, therefore reducing the stress concentration and having great influence on the mechanical properties. The homogeneous dispersion of CNTs in a polymer matrix plays a crucial role in the preparation of polymer composites based on interfacial interactions between CNTs and the polymer matrix. Establishing a poor dispersion leads to the agglomeration when the load is applied beyond limit, resulting in lower values of mechanical properties [149,150]. This phenomenon is in agreement with the findings of a previous study carried out by Jia et al. (1999) [151] on the investigation of PMMA as a matrix, together with CNT reinforcement. It could be observed that the tensile strength, toughness, and hardness rose with an increase of CNTs ranging from 1 to $7 \mathrm{wt} . \%$. However, the mechanical value decreased with the incorporation of CNTs up to $10 \mathrm{wt} . \%$. This was due to the strong tendency of CNTs to form agglomerates due to their large surface-area-to-volume ratio value, which makes interfacial bonding a critical factor responsible for the overall properties of composites. Furthermore, when more CNTs are blended with a polymer, the CNTs remain as entangled agglomerates, which inhibits their homogenous dispersion in the polymer matrix. Similar findings were observed by Yang et al. (2007) [152], who emphasized that the incorporation of CNT loading from 0.2 to $1.0 \mathrm{wt} . \%$ into the epoxy matrix improved not only the impact strength properties but also the tensile strength. The impact strength of the CNT/epoxy composite improved with the addition of $0.2-0.6 \mathrm{wt} . \%$ loading of MWCNTs to the epoxy, but then the value of the impact strength decreased with the addition of $0.8-1.0 \mathrm{wt} . \%$ of CNTs.

The alignment of CNTs, even with a minimum amount of CNT loading (less than $1 \mathrm{wt} . \%)$, is the third factor for the contribution of mechanical properties, as well as another important factor in the identification of overall mechanical properties [153]. Random orientation and perfectly aligned CNTs demonstrate the different behaviors of mechanical properties. Aligned types of carbon nanotube polymer composites tend to behave anisotropically, which is not required for bulk composites. This type of alignment is technical relevant for the optimum mechanical properties due to its effect on stiffness and strength, but it is always beneficial. The alignment of CNTs was induced by shear forces during the melt extrusion and fiber drawing processes in the development of CNT/polyimide composites by Siochi et al. (2004) [154]. This alignment of CNTs further resulted in significantly greater tensile strength and modulus properties of a polyimide/SWCNT composite 
that is displayed in Table 6 [154]. Furthermore, another study conducted by Kearns and Shambaugh (2002) [153] confirmed that the increment of the mechanical properties of the composites was significantly increased from 709 to $1032 \mathrm{MPa}$, with the addition of small amount of CNTs between 0 to $1 \mathrm{wt} . \%$, respectively.

Table 6. Tensile properties of polyimide/SWCNT composites.

\begin{tabular}{ccccc}
\hline $\begin{array}{c}\text { SWCNT } \\
\text { Loading (wt.\%) }\end{array}$ & $\begin{array}{c}\text { Tensile } \\
\text { Strength (MPa) }\end{array}$ & $\begin{array}{c}\text { Tensile } \\
\text { Modulus (GPa) }\end{array}$ & Elongation (\%) & $\begin{array}{c}\text { Toughness } \\
\left(\mathbf{m J} / \mathbf{m m}^{\mathbf{3}} \mathbf{)}\right.\end{array}$ \\
\hline 0 & 74 & 2.2 & 175 & 123 \\
\hline 0.1 & 86 & 2.6 & 125 & 100 \\
\hline 0.3 & 94 & 2.8 & 110 & 92 \\
\hline 1.0 & 100 & 3.2 & 20 & 6 \\
\hline
\end{tabular}

The most crucial factor among all listed factors is interfacial stress load transfer. It is assumed that CNTs will disproportionally exploit the maximum load amount and impart a major load carrier, thus leading to delay in crack propagation. It is important to mention that there are three types of mechanisms dictated by the interfacial interaction between CNTs and polymers that are called mechanical coupling, physical interaction, and chemical interaction. Mechanical coupling involves the entanglement of polymers with CNT fillers, as well as the formation of micro mechanical lock, whereas physical interactions involve Van der Waals forces, and chemical interactions involve the use of functional groups for the efficient dispersion of CNTs in polymer matrix resin, polymer wrapping [155], and plasma polymerization [156]. Xie et al. (2007) [157] investigated the efficient interfacial stress load transfer between SWCNTs and polymer density covalent layers via the grafting method approach. The functionalized SWCNTs exhibited a remarkable impact on the mechanical properties of the polystyrene composites. The addition of only $0.06 \mathrm{wt} . \%$ of SWCNTs significantly impacted the tensile strength and elastic modulus of the composites, indicating that an efficient stress load transfer had occurred in this CNT/polymer composite [158].

Remarkable efforts to improve the mechanical properties of CNT-polymer composites have been made since the early 1990s. It is well-understood that the loading of CNTs is usually selected under $10 \mathrm{wt} . \%$ in order to avoid an increment in viscosity, which ends up resulting in a poor processability and weak properties of polymer composites. A summary of mechanical properties of CNT-polymer composites from 2015 to 2020 is given in Table 7 .

Table 7. Summary of the mechanical properties of CNT-polymer composites from 2015 to 2020.

\begin{tabular}{|c|c|c|c|c|c|c|}
\hline Type of CNT & $\begin{array}{c}\text { Filler } \\
\text { Content }(\%)\end{array}$ & Matrix & $\begin{array}{l}\text { Fabrication } \\
\text { Technique }\end{array}$ & $\begin{array}{c}\text { Tensile } \\
\text { Strength (MPa) }\end{array}$ & $\begin{array}{l}\text { Tensile Modulus } \\
\text { (GPa) }\end{array}$ & Reference \\
\hline \multicolumn{7}{|c|}{ Thermoplastic polymer } \\
\hline MWCNTs & 2 wt. $\%$ & PC & Grafting extrusion & $\begin{array}{c}61 \\
(26 \% \text { increase }) \\
\end{array}$ & 1.45 & [159] \\
\hline MWCNTs & 8 wt. $\%$ & HDPE & $\begin{array}{l}\text { Compression molding } \\
\text { and blown film extrusion }\end{array}$ & $\begin{array}{c}18 \\
(34 \% \text { decrease }) \\
\end{array}$ & 2.3 & [160] \\
\hline MWCNTs & 15 wt. $\%$ & $\mathrm{PP}$ & $\begin{array}{l}\text { Melt mixing and } \\
\text { extrusion }\end{array}$ & $\begin{array}{c}47 \\
\text { (38\% increase) }\end{array}$ & 0.37 & [161] \\
\hline $\mathrm{Cu}$ MWCNTs & 2 wt. $\%$ & PLA/ESO & $\begin{array}{l}\text { Mechanical stirring and } \\
\text { sonication }\end{array}$ & $\begin{array}{c}0.8 \\
(54 \% \text { increase }) \\
\end{array}$ & 0.97 (33\% increase) & [162] \\
\hline MWCNTs & 1.5 wt. $\%$ & TPU & Sonication and stirring & $\begin{array}{c}63 \\
(40 \% \text { increase })\end{array}$ & $\begin{array}{c}0.095 \\
(280 \% \text { increase })\end{array}$ & {$[163]$} \\
\hline MWCNTs & $10 \mathrm{wt} . \%$ & UHMWPE & $\begin{array}{l}\text { Solution mixing and } \\
\text { sintering }\end{array}$ & $\begin{array}{c}22 \\
\text { (37\% increase) }\end{array}$ & $0.25(20 \%$ increase $)$ & {$[164]$} \\
\hline
\end{tabular}


Table 7. Cont

\begin{tabular}{|c|c|c|c|c|c|c|}
\hline Type of CNT & $\begin{array}{c}\text { Filler } \\
\text { Content (\%) }\end{array}$ & Matrix & $\begin{array}{l}\text { Fabrication } \\
\text { Technique }\end{array}$ & $\begin{array}{c}\text { Tensile } \\
\text { Strength (MPa) }\end{array}$ & $\begin{array}{l}\text { Tensile Modulus } \\
\text { (GPa) }\end{array}$ & Reference \\
\hline $\begin{array}{l}\text { Amide } \\
\text { MWCNTs }\end{array}$ & 0.5 wt. $\%$ & WBPU & Sonication and stirring & $\begin{array}{c}12 \\
(20 \% \text { increase) }\end{array}$ & $0.07(10 \%$ increase $)$ & [165] \\
\hline $\begin{array}{l}\text { Methanol } \\
\text { MWCNTs }\end{array}$ & 35 wt. $\%$ & TPU-acetone & Sonication & $\begin{array}{c}41 \\
(20 \% \text { increase) }\end{array}$ & $\begin{array}{c}1.27 \\
(950 \% \text { increase })\end{array}$ & {$[165]$} \\
\hline $\begin{array}{c}\text { Iron (III) } \\
\text { acetylaceto- } \\
\text { nate } \\
\text { MWCNTs }\end{array}$ & 1.5 wt. $\%$ & TPU & Sonication and stirring & $\begin{array}{c}14 \\
(100 \% \text { increase })\end{array}$ & & {$[166]$} \\
\hline MWCNTs & 5 wt. $\%$ & PP & $\begin{array}{l}\text { Grinding and injection } \\
\text { molding }\end{array}$ & 36 & 1.8 & {$[167]$} \\
\hline SWCNTs & 1 wt. $\%$ & PS & Ultrasonication & $\begin{array}{c}12.7 \\
(12 \% \text { increase) }\end{array}$ & $\begin{array}{c}0.01 \\
(11 \% \text { decrease) }\end{array}$ & {$[168]$} \\
\hline $\begin{array}{c}\text { Acid } \\
\text { MWCNT }\end{array}$ & 5 wt. $\%$ & PMMA & Solution mixing & $\begin{array}{c}30 \\
(200 \% \text { increase })\end{array}$ & $\begin{array}{c}1.3 \\
(188 \% \text { increase })\end{array}$ & [169] \\
\hline MWCNTs & 1 wt. $\%$ & $\mathrm{PP}$ & $\begin{array}{l}\text { Ultrasonication and } \\
\text { hot-pressing }\end{array}$ & 25 & 2 & [170] \\
\hline \multicolumn{7}{|c|}{ Thermosetting polymer } \\
\hline $\begin{array}{c}\mathrm{ZnO} \\
\text { MWCNTs }\end{array}$ & 1.7 wt. $\%$ & Epoxy & Sonication & $\begin{array}{c}61 \\
\text { (20\% increase) }\end{array}$ & $\begin{array}{c}3.6 \\
\text { (51\% increase) }\end{array}$ & [171] \\
\hline MWCNTs & 56 wt. $\%$ & Epoxy & $\begin{array}{l}\text { CVD, rolling, and } \\
\text { hot-pressing }\end{array}$ & & 15.5 & {$[148]$} \\
\hline MWCNTs & 1 wt. $\%$ & Epoxy & Ultrasonication & $\begin{array}{c}125 \\
(160 \% \text { increase })\end{array}$ & - & [145] \\
\hline $\begin{array}{l}\text { Gelatin } \\
\text { MWCNTs }\end{array}$ & 0.5 wt. $\%$ & Epoxy & $\begin{array}{l}\text { Mechanical mixing and } \\
\text { sonication }\end{array}$ & $\begin{array}{c}98(16 \% \\
\text { increase })\end{array}$ & $2.91(18 \%$ increase $)$ & [146] \\
\hline MWCNTs & $3 w t . \%$ & Epoxy & $\begin{array}{l}\text { Ultrasonication and } \\
\text { sonication }\end{array}$ & $\begin{array}{c}31.42 \\
(192 \% \text { increase })\end{array}$ & - & [172] \\
\hline MWCNTs & $3 w t . \%$ & Epoxy & $\begin{array}{l}\text { Ultrasonication and } \\
\text { sonication }\end{array}$ & 339.90 & - & [172] \\
\hline MWCNTs & 1 wt. $\%$ & Epoxy & $\begin{array}{l}\text { Ultrasonication and } \\
\text { sonication }\end{array}$ & $105 \%$ increase & - & [173] \\
\hline MWCNTs & 3 wt. $\%$ & Epoxy & $\begin{array}{l}\text { Ultrasonication and } \\
\text { sonication }\end{array}$ & $\begin{array}{c}52.225 \\
(65 \% \text { increase })\end{array}$ & - & [174] \\
\hline MWCNTs & 3 wt. $\%$ & Epoxy & Ultrasonication & $\begin{array}{c}230.13 \\
(70.6 \% \text { increase })\end{array}$ & - & {$[175]$} \\
\hline MWCNTs & 3 wt. $\%$ & Epoxy & Ultrasonication & $\begin{array}{c}24.83 \\
(127 \% \text { increase })\end{array}$ & - & [175] \\
\hline CNTs & $5 w t . \%$ & Epoxy & $\begin{array}{l}\text { Extrusion and powder } \\
\text { impregnation }\end{array}$ & $\begin{array}{c}81 \\
(30 \% \text { increase }) \\
\end{array}$ & - & {$[77]$} \\
\hline $\begin{array}{c}\text { TA- } \\
\text { PEI/MWCNTs }\end{array}$ & 0.4 wt. $\%$ & Epoxy & Ultrasonication & $\begin{array}{c}80.83 \\
(148 \% \text { increase })\end{array}$ & - & {$[77]$} \\
\hline Straight CNTs & 0.1 wt. $\%$ & Epoxy & $\begin{array}{l}\text { Sonication and } \\
\text { magnetic stirring }\end{array}$ & $\begin{array}{c}72.91 \\
\text { (13.21\% increase) }\end{array}$ & $\begin{array}{c}25 \\
(25.86 \% \text { increase })\end{array}$ & [175] \\
\hline Helical CNTs & 0.05 wt. $\%$ & Epoxy & $\begin{array}{l}\text { Sonication and } \\
\text { magnetic stirring }\end{array}$ & $\begin{array}{c}72.75 \mathrm{MPa} \\
(12.96 \% \text { increase })\end{array}$ & $\begin{array}{c}23.96 \\
(25.24 \% \text { increase })\end{array}$ & {$[175]$} \\
\hline
\end{tabular}


Table 7. Cont.

\begin{tabular}{|c|c|c|c|c|c|c|}
\hline Type of CNT & $\begin{array}{c}\text { Filler } \\
\text { Content }(\%)\end{array}$ & Matrix & $\begin{array}{l}\text { Fabrication } \\
\text { Technique }\end{array}$ & $\begin{array}{c}\text { Tensile } \\
\text { Strength (MPa) }\end{array}$ & $\begin{array}{l}\text { Tensile Modulus } \\
\text { (GPa) }\end{array}$ & Reference \\
\hline MWCNTs & 7.5-16 wt.\% & Epoxy & $\begin{array}{l}\text { Epoxidation and } \\
\text { chemical treatment }\end{array}$ & $\begin{array}{c}203 \mathrm{MPa} \\
(50 \% \text { increase) }\end{array}$ & $8.4(144 \%$ increase $)$ & [77] \\
\hline CNT fiber & $0.1-2$ wt. $\%$ & Epoxy & Direct spinning & $\begin{array}{c}2.1 \mathrm{~N} / \text { tex } \\
(313 \% \text { increase })\end{array}$ & - & [100] \\
\hline $\begin{array}{l}\text { Pyrogallol } \\
\text { MWCNT }\end{array}$ & $1.5 w t . \%$ & Epoxy & Mechanical mixing & $\begin{array}{c}76 \\
\text { (24\% increase) }\end{array}$ & - & [144] \\
\hline MWCNTs & 0.4 wt. $\%$ & Epoxy & $\begin{array}{l}\text { Mechanical mixing and } \\
\text { hot pressing }\end{array}$ & $\begin{array}{c}42 \\
(2 \% \text { decrease })\end{array}$ & $\begin{array}{c}2 \\
\text { (2\% decrease) }\end{array}$ & [147] \\
\hline
\end{tabular}

Abbreviations: epoxidized soybean oil (ESO), high density polyethylene (HDPE), polycarbonate (PC), polyethylene (PE), polylactic acid (PLA), polyethyleneimine (PEI), polypropylene (PP), tannic acid (TA), thermoplastic polyurethane (TPU), ultra high molecular weight polyethylene (UHMWPE), waterborne polyurethane (WBPU).

\subsection{CNT-Reinforced Polymer Composites on Thermal Performance}

CNTs with a thermal conductivity an average of 10-fold lower than metals/ceramics have shown great success as good thermal insulators [90]. Furthermore, additional physical characteristics in terms of their light weight, cost-effectiveness, and corrosion resistance are very importance in the future trend of nanocomposite technology [176]. Interestingly, these characteristics can be envisioned as new possibilities for various applications of their thermal properties such as thermal interface materials, heat sinks, printed circuit boards, connectors, and other high-performance thermal management systems [90]. However, there is still a significant challenge faced among researchers of CNTs in terms of lowering CNT loading to provide a higher thermal conductivity [177].

The existence of shielded internal layer in MWCNTs could be promising for the conduction of phonon and the reduction of matrix coupling losses. These properties have shown that MWCNTs can provide the most significant improvement in thermal conductivity-reinforced polymer composites [90]. The extent to which MWCNTs correspond with the significant progress of thermal conductivity in polymer composites can be observed in Table 8. Not surprisingly, most polymers are combined with multi-walled carbon nanotubes to obtain a higher thermal conductivity depending on their application (Table 8). In addition, the affecting factors that influence the making of CNTs as very promising material in providing higher thermal conductivity also need to be studied to solve a significant challenge in CNTs, which is in lowering the loading value of CNTs to have a higher thermal conductivity [177]. Among the main factors influencing thermal conductivity is polymer morphology $[178,179]$. Markers for the prediction of higher thermal conductivity based on polymer morphology have been widely investigated, and it has been shown that more defects at the crystalline structures, the lower the intrinsic thermal conductivity of the crystal. This leads to phonon scattering, which is known to shorten the mean free path that finally reduced the thermal conductivity [176]. The morphology of CNT reinforced polymer composites significantly affect thermal properties. This can be observed through different mechanisms in the alignment of structure such as mechanical stretching [180], nano templating $[178,181]$, and electrospinning $[178,180,182]$. Therefore, a clear understanding of the mechanisms involved in polymer morphology will contribute to the improvement of studies in designing a composite with a high thermal conductivity. 
Table 8. Transmissions in the thermal properties of various CNT-polymer composite materials based on their application.

\begin{tabular}{|c|c|c|c|c|c|}
\hline Type of Polymer & Type of CNT & CNT Content (wt.\%) & Improvement Properties & Potential Application & Reference \\
\hline- & SWCNT & 100 wt. $\%$ & Up to $3500 \mathrm{~W} / \mathrm{m} \cdot \mathrm{K}$ & $\begin{array}{l}\text { Heat sinks, connectors, batteries, light-emitting diode } \\
\text { devices, automotive electronic control units, printed } \\
\text { circuit boards, electronic assembly, and packaging }\end{array}$ & [177] \\
\hline Polyacrylate composites & MWCNT & 50-80 wt. $\%$ & $\wedge \sim 0.50$ to $1.67 \mathrm{~W} / \mathrm{m} \mathrm{K}$ & Aerospace and aeronautics material & [183] \\
\hline PLA & MWCNT & $0.25-2.5$ wt. $\%$ & $27.5 \mathrm{~mW} \cdot \mathrm{m}^{-1} \mathrm{~K}^{-1}$ & High performance thermal insulator & [184] \\
\hline Poly-dimethyl siloxane & MWCNT & $\sim 2$ wt. $\%$ & $\wedge \sim 1.5 \mathrm{~W} / \mathrm{m} \cdot \mathrm{K}$ & $\begin{array}{l}\text { Thermal insulator/high thermal conductivity } \\
\text { polymer composites }\end{array}$ & [185] \\
\hline Polymer-based composite & CNTs & $30 \%$ & $1000-4000 \mathrm{~W} / \mathrm{m} \cdot \mathrm{K}$ & Light-emitting diodes and thermal dissipation & [179] \\
\hline Polystyrene & MWCNT & $1 \%$ & $\begin{array}{l}\sim 30.2 \mathrm{~mW} / \mathrm{m}-\mathrm{K} \text { without using } \\
\text { any insulation gas }\end{array}$ & Super-thermal insulation properties & [186] \\
\hline Poly (vinylidene fluoride) & MWCNT/graphene(1:1) & $\begin{array}{c}10 \% \text { of (s-MWCNTs)/ } \\
\text { graphene (GE) }\end{array}$ & $\begin{array}{l}\wedge \sim 711.1 \% \text { of } 0.19 \mathrm{~W} / \mathrm{m} \cdot \mathrm{K} \\
\quad \approx 135.11 \mathrm{~W} / \mathrm{m} \cdot \mathrm{K}\end{array}$ & Heat exchanger & [187] \\
\hline PC & MWCNT & $2 \%$ & $\wedge \sim 1.27 \mathrm{~W} / \mathrm{m} \cdot \mathrm{K}$ & High performance thermal insulator & [188] \\
\hline \multirow{3}{*}{$\begin{array}{l}\text { Carbon prepreg (IM7) } \\
\text { composite }\end{array}$} & \multirow{3}{*}{ SWCNT } & \multirow{3}{*}{$30 \%$} & $\wedge 30 \%$ heat capacity & \multirow{3}{*}{$\begin{array}{l}\text { Pipes and heat exchangers, replacer material for } \\
\text { heavy-lift rocket under the Space Launch System } \\
\text { (SLS), and promising high performance material for } \\
\text { future space vehicles. }\end{array}$} & \multirow{3}{*}{ [190] } \\
\hline & & & $\wedge 30 \%$ thermal diffusivity & & \\
\hline & & & $\begin{array}{l}\wedge \sim 120-150 \% \text { thermal } \\
\text { conductivity }\end{array}$ & & \\
\hline Epoxy & MWCNT & 0.3 wt. $\%$ & $\begin{array}{l}\wedge 35-42 \% \text { of critical buckling } \\
\text { temperature }\end{array}$ & $\begin{array}{l}\text { Coefficient of thermal expansion (CTE) and thermal } \\
\text { buckling of epoxy-based composites }\end{array}$ & [191] \\
\hline \multirow[t]{2}{*}{ Epoxy } & \multirow[t]{2}{*}{ SWCNT } & 1 wt. $\%$ & $\begin{array}{c}\wedge \sim 125 \% \mathrm{~W} / \mathrm{m} \cdot \mathrm{K} \\
\text { (method raw laser-oven) }\end{array}$ & \multirow[t]{2}{*}{ High performance thermal insulator } & \multirow[t]{2}{*}[90]{} \\
\hline & & 3 wt. $\%$ & $\wedge \sim 30 \% \mathrm{~W} / \mathrm{m} \cdot \mathrm{K}$ & & \\
\hline
\end{tabular}




\subsection{CNT-Reinforced Polymer Composites on Electrical Performance}

One of the most exceptional properties of CNT-reinforced polymer composites that has brought them to another level of remarkable multifunctional materials is electrical performance. With CNTs, polymer composites have found significant value in electrical field applications such as solar cells, integrated circuits, sensors, aerospace, and shielding [192-194]. CNTs possess an electrical conductivity as high as $10^{6}-10^{7} \mathrm{Sm}^{-1}$ due to the fact that, even at very low filler loading, reinforced polymer composites with exceptional conductivity can be obtained [195]. Nanostructure size also plays an important role in inducing excellent conducting behavior through its ability to allow for homogenous embedding in polymer matrices. Here, various types of emerging organic polymers reinforce CNTs such as polyaniline (PANI) / $\leq 8 \mathrm{wt} . \% \mathrm{f}-\mathrm{MWCNT}$ with an electrical conductivity of about $28.6 \mathrm{Sm}^{-1}$ [196], polyamide/7 wt.\% MWCNT with an electrical conductivity of $\sim 10^{1} \mathrm{Sm}^{-1}$ [194], PVDF/0.5 wt.\% MWCNT with an electrical conductivity of about $0.8 \mathrm{Sm}^{-1}$ [197], PC/ $\leq 3 \mathrm{wt} . \%$ SWCNT with an electrical conductivity of about $10^{1} \mathrm{Sm}^{-1}$ [198], and polypropylene (PP) / $\leq 3.5 \mathrm{wt} . \%$ MWCNT with an electrical conductivity of about $2.0 \times 10^{1} \mathrm{Sm}^{-1}$ [193] were reviewed to study this property. On this subject, studies have focused on the mechanisms and factors that facilitate and affect electrical conductivity in the CNT-reinforced polymer composites.

\subsubsection{Mechanism of Electrical Conductivity}

Man reports [199-203] have indicated that the incorporation of CNTs with polymers leads to a lower percolation threshold due to the high aspect ratio and intrinsic conductivity of CNTs. The percolation threshold in a polymer matrix composite is the minimum content of filler that allows for no changes in the electrical conductivity of the composite. As such, when the concentration or weight \% of the filler exceeds the percolation threshold (upon stipulated states), conductivity increases (Figure 10) [204]. The introduction of CNTs into a polymer matrix lowers the percolation threshold because the nanotubes are covalently incorporated into the polymer cross-linked structure. This network structure of fillers create conductive paths where the CNTs are in close contact to each other, thus facilitating the conduction of electron through 'hopping' or 'tunnelling' mechanisms [100]. Therefore, with increased volume fractions of CNTs, the network paths intensify and hence abruptly increase the conductivity of reinforced polymer matrices. Experimental approaches based on this interesting mechanism of dispersion are further discussed in the next sub-section of factors that affect the electrical conductivity of CNT-reinforced polymer composites (filler loading amount).

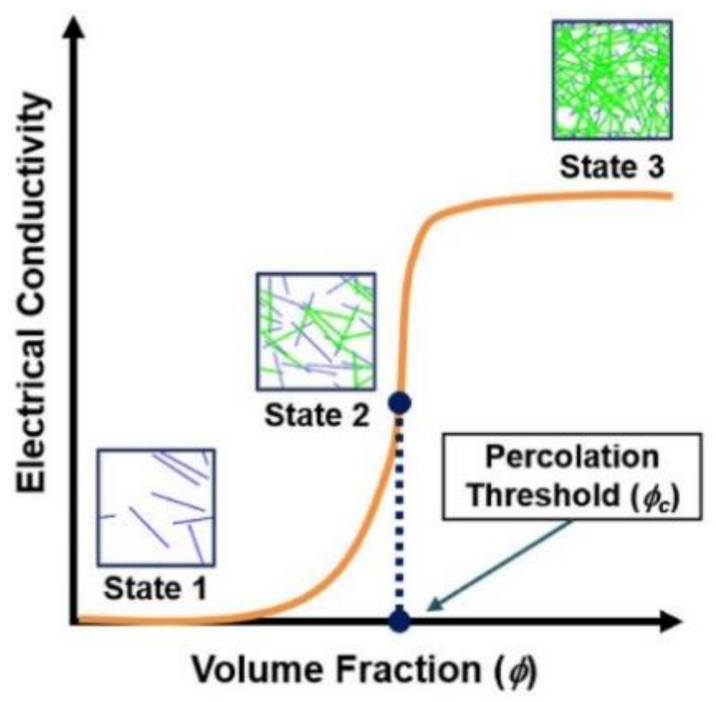

Figure 10. Classifications of three different states concerning the percolation theory-based electrical conductance transition for CNT-filled polymer nanocomposites. Reproduced from [204]. 
There have been supportive studies on percolation theory [205-207] that discussed the importance of dispersion quality in assisting the increment of electrical conductivity which, is also supported by theoretical models. It has been established that there are three main mechanisms of conductivity in percolating CNT networks: (1) the electrical conductivity of the CNTs themselves, (2) the direct contact conductance at the microscale, and (3) the nanoscale phenomenon of electron hopping or tunnelling. These three mechanisms of conductivity have become the guidelines for proposed models for the quantitative prediction on electrical conductivity of CNT-reinforced polymer composites [202]. The Monte Carlo method has been widely used to investigate the electrical percolation behavior of CNT-reinforced polymer composites. The method has allowed for the evolution of numerical predictions with unlimited forms of filler structures, whether powders or films with wide ranges of dimensions. Ni et al. (2018) [208] applied this method in their study to come up with numerical predictions of the percolation threshold of an insulating thin film that was reinforced with 1D and 2D conductive fillers. Mechanism parameters such as size effect, concentration, and contact patterns of nanofillers were carefully examined for the prediction. Their prediction showed that different dimensions of nanofillers can coexist and give a synergistic effect to obtain an effective conductance.

\subsubsection{Factors Affecting Electrical Conductivity of CNT-Reinforced Polymer Composites}

There are many factors that affect the electrical conductivity of CNT-reinforced polymer composites. Significant factors that have been identified from theoretical models and experiment works are (1) the dispersion of CNTs, (2) the filler loading amount, (3) the structure of CNTs, and (4) the type of polymer.

\section{Dispersion of CNTs}

In an experiment, Gao et al. (2018) [209] prepared incorporated CNTs with polyurethane (PU)/polyethersulfone (PES) nanofibers using ultrasonication, which resulted in highly dispersed CNTs on the nanofiber surface upon ultrasonication time. The dispersion constructed electrically-conductive networks with an ultralow percolation threshold of 0.056 vol. $\%$, which led to a significantly high electrical conductivity at $2.8 \mathrm{Sm}^{-1}$ at a relatively low CNT concentration of 0.85 vol.\%. Moreover, with the aim to improve the epoxy resin's electrical performance, Trakakis et al. (2020) [100] produced CNT/epoxy nanocomposites using the bucky papers approach. This approach allowed for better CNTs dispersion into the matrix with longer CNTs, which improved the total conductivity of the nanocomposites. The report showed a significant increase of the electrical conductivity (from 0.17 to $0.57 \mathrm{Sm}^{-1}$ ) of the insulated epoxy resin to a level that was comparable to semiconductors.

\section{Filler Loading Amount}

Recently, Chen and Han (2020) [200] focused on identifying the causes that may lead to an improvement of the electrical conductivity in reinforced, CNT-derived epoxy polymers. The findings led them to the agreement of the electrical percolation threshold theory. They found that the electrical percolation threshold existed in all their derived composite materials, which exhibited increments of electrical conductance upon the increased concentration of CNTs. They found that the conductivities increased by up to $10^{1} \mathrm{Sm}^{-1}$ when the CNT content increased from 1 to $5 \mathrm{wt} . \%$.

Segregated conductive polymer composites (CPCs) possess a very low electrical percolation threshold (1.62 wt.\%) because the segregation provide pathways for electron conduction. However, CPCs suffer from a poor mechanical strength and brittle nature. Concerned about this problem, W. Zhai et al. (2018) [210] developed an easy technique to fabricate CPCs. They introduced plunger-type injection molding (PTIM) to sustain the segregated structure while simultaneously improving the mechanical strength. Their effort showed a positive hypothesis, because the resistivity of all samples exponentially decreased with the increasing CNT content. However, the decrease in resistivity explained 
the increase of conductivity. Furthermore, an impressive threshold percolation of about 0.13 vol. $\%$, which was 30 times lower than the specimens gained from the conventional injection, was obtained.

\section{Structure of CNTs}

Researchers have been more attracted to MWCNTs than SWCNTs. This is because the densities of MWCNTs are higher than SWCNTs, which makes MWCNTs possess lower surface areas and higher aspect ratios. These enable good dispersibility, hence increasing the electrical conductance of polymer matrixes. With the application of an externally applied field, Gupta et al. (2016) [197] showed that a CNT-incorporated PVDF matrix significantly increased conductivity by a huge order of $10-10^{5} \mathrm{Sm}^{-1}$ for CNT/PVDF compared to only $10^{-5} \mathrm{Sm}^{-1}$ for PVDF. Additionally, the method of preparation through stirring and ultrasonication helped to provide a better dispersibility of CNTs, which is another factor that contributes to a high conductivity. Later, T. Yamamoto and K. Kawaguchi [211] produced a copolymer (styrene monomer, benzyl methacrylate and methyl methacrylate) via in situ polymerization. To obtain a high dispersibility, they dispersed MWCNTs with very fine membranes (100 nm pores), which ensured the formation of conductive paths and thus enabled a significant conductivity result of $1.2 \mathrm{Sm}^{-1}$ with only $0.5 \mathrm{wt}$ \% of CNT content.

Attractive novel MWCNT/phosphate glass (Pglass)-reinforced PP hybrids were proposed by L. Zhang et al. (2018) [193] to come out with highly controllable dispersibility and fine morphology nanofillers. It is well-known that hybridization may lead to new property outcomes while maintaining existing ones, which is a strategy to diversify matrix applications. Typically, Pglass is composed of inorganic semiconductor oxides such as $\mathrm{SnO}, \mathrm{P}_{2} \mathrm{O}_{5}$, and $\mathrm{SnF}_{2}$. Uniquely, it possesses polymer-chain-like molecular structure with an ultra-low glass transition temperature $\left(40-200{ }^{\circ} \mathrm{C}\right)$, hence allowing for homogeneous blends of Pglass and polymer for controllable dispersion with a tuned morphology of Pglass during processing. With the increased content of CNT/Pglass in the matrix, the electrical conductance greatly improved to as high as $21.9 \mathrm{Sm}^{-1}$.

Despite having less attention, SWCNTs play important roles in more specific application such as the aircraft industry. Their lesser density property allows for the production of a light weight matrix, as proven by Q. Xia et al. (2020) [212]. They produced a highly conductive silver modified CNT film via electrophoretic deposition (EPD) for protecting carbon fiber-reinforced polymer structures and components of aircraft. In comparison to conventional metallic materials, the utilization of CNTs reinforced polymer composite decreases aircraft fuel consumption and increases fatigue resistance. This significant improvement is evident in Boeing 787 body structures and components built using 50\% of CFRP composite by weight.

\section{Type of Polymers}

As summarized in Table 8, polymers exist in two main groups: thermoplastic and thermoset. Both have been used as polymer-based matrices for engineering polymer nanostructures. Consequently, thermoplastics have been found to have low melting points (high solubility), while thermosets can withstand higher temperatures without a loss of their structural integrity (superior strength). Their electrical performance is discussed below.

(a) Thermoplastic polymers: PP is known to be one of the highly favored thermoplastic polymers due to its high solubility in aqueous media and low cost. Being a thermoplastic commodity, PP has the advantage of recyclability with remarkable physical, thermal, and mechanical properties. PANI also has similar advantages and has been a subject of reinforced polymer research for many years [213-215]. Sobha et al. (2017) [196] successfully produced highly disperse functional MWCNTs (f-MWCNT) in thermoplastic polyurethane (TPU) composites based on PANI via an in-situ polymerization assisted by ultra-sonication. The well-dispersed and reduced aggregation 
of f-MWCNTs contribute to a very low percolation threshold at only $0.58 \mathrm{wt} . \%$, hence exhibiting a significant conductivity of $28.6 \mathrm{Sm}^{-1}$. The results showed promising applications, mostly as coating and electromagnetic interference shielding.

(b) Thermoset polymers: As a conducting polymer, polypyrrole (PPy) has been widely used due to its superiority in optical and electrical properties. It possesses a high efficiency response towards visible light, a high carrier mobility, and an excellent thermal and chemical stability. Recently, by looking into these advantages, Saheeda and Jayaleksmi (2020) [216] successfully synthesized a nanocomposite of PPy and MWCNTs via liquid/liquid interfacial polymerization. In this study, they found that a strong interfacial interaction between the polymer and MWCNTs occurred. This led to the establishment of a high electrical conductivity of $8.05 \times 10^{2} \mathrm{Sm}^{-1}$. Furthermore, the nanocomposite also possessed excellent nonlinear optical properties that suggested promise for its application in solar cells. Table 9 presents the properties of the electrical conductance of various CNTs and polymers, as well as their potential applications.

Table 9. Electrical conductance of CNTs and polymers with potential applications.

\begin{tabular}{|c|c|c|c|c|c|}
\hline Polymer & $\begin{array}{l}\text { Types of } \\
\text { CNT }\end{array}$ & $\begin{array}{l}\text { CNT Content } \\
\quad(w t . \%)\end{array}$ & $\begin{array}{c}\text { Maximum Conductivity, } \\
\sigma_{\max }\left(\mathrm{Sm}^{-1}\right)\end{array}$ & Potential Applications & Reference \\
\hline \multicolumn{6}{|c|}{ Thermoplastics polymer } \\
\hline $\mathrm{PP}$ & MWCNT & $\leq 3.5$ & 21.9 & $\begin{array}{l}\text { Conductive adhesive, coating, } \\
\text { and resistor }\end{array}$ & [193] \\
\hline PC & $\begin{array}{l}\text { SWCNT } \\
\text { MWCNT }\end{array}$ & $\begin{array}{l}\leq 3.0 \\
\leq 10.0\end{array}$ & $\begin{array}{c}1.0 \times 10^{2} \\
0.9\end{array}$ & $\begin{array}{l}\text { Lightning strike protector, } \\
\text { shielding, and coating }\end{array}$ & [198] \\
\hline PMMA & MWCNT & $\leq 3.0$ & $2.0 \times 10^{-4}$ & $\begin{array}{l}\text { Electromagnetic interference } \\
\text { shielding }\end{array}$ & [217] \\
\hline Ethylene-1-octene & MWCNT & 2.0 & $2.0 \times 10^{-5}$ & Sensor, shielding & [218] \\
\hline $\begin{array}{l}\text { Pyridinium salt } \\
\text { polymer }\end{array}$ & SWCNT & $50 \%$ (content) & $1.6 \times 10^{4}$ & Thermoelectric materials & [219] \\
\hline $\mathrm{PP}$ & MWCNT & $3.2(\mathrm{vol} . \%)$ & $1.2 \times 10^{7}$ & $\begin{array}{l}\text { Electromagnetic shielding, } \\
\text { anti-static cover, and chemical } \\
\text { sensing }\end{array}$ & {$[210]$} \\
\hline PANI & f-MWCNT & $\leq 8.0$ & 28.6 & $\begin{array}{l}\text { Electromagnetic interference } \\
\text { shielding }\end{array}$ & [196] \\
\hline \multicolumn{6}{|c|}{ Thermosetting polymer } \\
\hline Derived epoxy & $\begin{array}{l}\text { Hydroxyl- } \\
\text { functionalized } \\
\text { SWCNT }\end{array}$ & $\leq 5.0$ & $10^{1}$ & $\begin{array}{l}\text { Metal replacement, sensor, } \\
\text { and shielding }\end{array}$ & {$[200]$} \\
\hline Polyamide & MWCNT & 7 & 6 & $\begin{array}{l}\text { Shielding, conductive } \\
\text { adhesive, and coating }\end{array}$ & [194] \\
\hline Epoxy & MWCNT & 0.73 & $2.5 \times 10^{-2}$ & Sensor and shielding & [5] \\
\hline $\begin{array}{c}\text { Carbon } \\
\text { fiber-reinforced } \\
\text { polymer }\end{array}$ & SWCNT & - & $5.0 \times 10^{5}$ & $\begin{array}{l}\text { Lightning strike protector, } \\
\text { shielding, coating, and } \\
\text { thermoelectric materials }\end{array}$ & [212] \\
\hline PVDF & MWCNT & 0.5 & 0.8 & $\begin{array}{l}\text { Conductive adhesive and } \\
\text { coating }\end{array}$ & [197] \\
\hline Vinyl ester & MWCNT & $\leq 0.5$ & $10^{-1}$ & $\begin{array}{l}\text { Electromagnetic shielding and } \\
\text { sensor }\end{array}$ & [220] \\
\hline PPy & MWCNT & $\leq 0.5$ & $8.05 \times 10^{2}$ & Solar cells and Li-ion battery & [216] \\
\hline
\end{tabular}




\subsection{Environmental Concern and Health and Safety Issues of CNTs}

The toxicity and health and safety issues presented by some forms of the material from CNTs depend on several factors like aspect ratio, length, surface area, degree of aggregation, purity, and concentration [221].

\subsubsection{Aspect Ratio}

The difference between CNTs and other types of commercial reinforcing fillers including carbon black, clays, and carbon fibers is that a better compatibility of CNTs with polymers could be obtained with smaller aspect ratio CNTs, representing the formation of more uniform CNT/polymer composites. The high aspect ratio of CNTs means dynamic light scattering techniques are unsuitable for generating accurate particle sizes in dispersion [222]. Thus, it has been proposed that for the determination of more relevant particle size data and particle size distributions of CNTs, SEM and TEM imaging are better options. Therefore, in order to ensure health and safety while exposing CNTs to the environment, the occupational exposure limit values (OELs) standard had been conducted as legislation applicable to nanomaterial handling. Information regarding OELs for nanomaterials is presented in Table 10 [223].

Table 10. Occupational exposure limit values (OELs) for nanomaterial handling.

\begin{tabular}{cc}
\hline Description & Benchmark Exposure Level \\
\hline Fibrous, a high aspect ratio insoluble nanomaterials & 0.01 fibers $/ \mathrm{mL}$ \\
\hline $\begin{array}{c}\text { Any nanomaterial that is already classified in its molecular or } \\
\text { in its larger particle form a as carcinogenic, mutagenic, } \\
\text { reproductive, and sensitizing (CMRS) toxin }\end{array}$ & $0.1 \times$ OEL \\
\hline $\begin{array}{l}\text { Insoluble or poorly soluble nanomaterials not in the fibrous or } \\
\text { CMRS categories }\end{array}$ & $0.066 \times$ OEL \\
\hline Soluble nanomaterials not in the fibrous or CMRS categories & $0.5 \times$ OEL \\
\hline
\end{tabular}

\subsubsection{Length}

Several experiments have been conducted to study the relationship between different lengths of MWCNTs and pulmonary fibrosis [224]. Based on the obtained results, long MWCNTs have much heavier adverse pulmonary effects compared to short MWCNTs. The size and the composition of a nanomaterial play a major role in the cellular response, which is related to the physiological function of the cell [225]. Observations showed that inflammation, fibrosis, and angiogenesis can be triggered by MWCNTs due to their length, iron contents, or crystal structure [226].

\subsubsection{Surface Area}

Another critical aspect that has been pointed out as a factor of toxicity is the surface area of CNTs. In a study by Kim et al. (2010) [227], the toxicity of a nanomaterial was found to be highly affected by its physical properties, like the size distribution and surface area reactivity of particles. In bronchoalveolar lavage fluid (BALF) cell analysis, pristine multiwalled carbon nanotubes (pMWCNTs) induced more severe acute inflammatory cell recruitment than acid-treated multiwalled carbon nanotubes (tMWCNTs). This was due to the fact that the reduction in size to the nano scale increases the surface area ratio of the materials and therefore increased the potential to cause damage; but this phenomenon was not possible while they were in larger forms [228].

\subsubsection{Concentration}

In order to further understand the relationship between CNT behavior and toxicity, concentration is another critical aspect that needs to be studied. In a study on mice that were exposed to the pharyngeal aspiration of purified pristine SWCNTs, the dose-dependence and time-course of pulmonary responses were examined [229]. Based on the obtained 
results, the SWCNTs produced acute inflammation, progressive fibrosis, the formation of granulomas, and an increase in protein levels, all of which were validated and detected.

\subsubsection{Cost}

It is well-known everywhere that costs comprise another issue that is related to health and safety. A cost-effective solution can be a factor worth considering for handling the health and safety issues related to CNTs. The evaluation of cost efficiency must be done with a holistic approach. In order to implement the final calculation of the cost of safety of a nanomaterial, a list of the main parameters was designed and implemented [230]. A list of main parameters included costs related to raw materials, equipment, insurance, security, decommissioning, and software. This practice was applied in the development phase, giving guidance to the technology selection and the subsequent improvement of safety and sustainability [231].

\section{Applications and Potential Use of Carbon Nanotube-Reinforced Polymer Composites}

Polymeric composites are one of the most well-known materials that have lightweight properties and high durability for various functions [232-239]. Polymer composites exploit a wide range of applications due to their all-around excellent performance in mechanical, thermal, and electrical properties [240-245]. The inclusion of nanofillers inside polymer resins could provide promising properties for materials in almost every sector [246-248]. Due to high cost of carbon fibers, CNTs can be added in small quantities in polymeric composites but exhibit while exhibiting strong mechanical properties [249]. For instance, the application of CNTs as reinforcements in polymeric composites could establish significantly high mechanical strength and elastic modulus values in comparison other high performance fibers such as Kevlar and carbon [143,250,251]. To be specific, their tensile strength and elastic modulus have been recorded at $150 \mathrm{GPa}$ and $1 \mathrm{TPa}$, respectively, which marks them as tremendously stronger and stiffer, as well as three-to-five times lighter, than steel. These properties can be characterized by using a proper testing facilities $[252,253]$ to ensure the qualities are on par with current conventional materials. Since these materials have shown significant enhancement in term of their material properties, Table 11 summarizes recent research on CNT-polymer composites conducted in various sectors.

Table 11. Recent progress of CNT-polymer composites.

\begin{tabular}{|c|c|c|c|}
\hline Applications & Types of CNT & Polymers & References \\
\hline $\begin{array}{c}\text { Biomedical goods, space vehicles, and } \\
\text { stations }\end{array}$ & SWCNT & Poly (4-methyl-1-pentene) & [254] \\
\hline Biocatalytic films & SWCNT & PMMA & [255] \\
\hline $\begin{array}{l}\text { Actuators and sensors for biomedical } \\
\text { Applications }\end{array}$ & MWCNT & $\begin{array}{l}\text { Poly (vinyl alcohol) and poly }(2- \\
\text { acrylamido-2-methyl-1-propane } \\
\text { sulfonic acid) }\end{array}$ & [256] \\
\hline Supercapacitor electrode materials & MWCNT & $\begin{array}{c}\text { PPy, } \\
\text { Poly-(3,4-ethylenedioxythiophene) } \\
\text { and PANI }\end{array}$ & [257] \\
\hline $\begin{array}{c}\text { External body components of automotive, } \\
\text { yarn fiber, conductive plastic, and hot } \\
\text { melt adhesives }\end{array}$ & MWCNT & PE & [258] \\
\hline $\begin{array}{l}\text { Electronics, electrostatic discharge, and } \\
\text { automotive and industrial goods }\end{array}$ & SWCNT and MWCNT & Polyamide & [6] \\
\hline Wind turbine blade and flame retardant & SWCNT and MWCNT & PU & [259] \\
\hline
\end{tabular}

CNTs are emerging advanced materials with outstanding mechanical, electrical, and thermal properties and highly interfacial contact areas. in comparison to other polymers, 
cnt-polymer composites have received more attention among material scientists due to the good compatibility between cnt and polymers. Figure 11 shows the potential and current applications of CNT-polymer composites including electronics, automobiles, textiles, aerospace, sport equipment, sensors, energy storage devices, and filters [260-262].

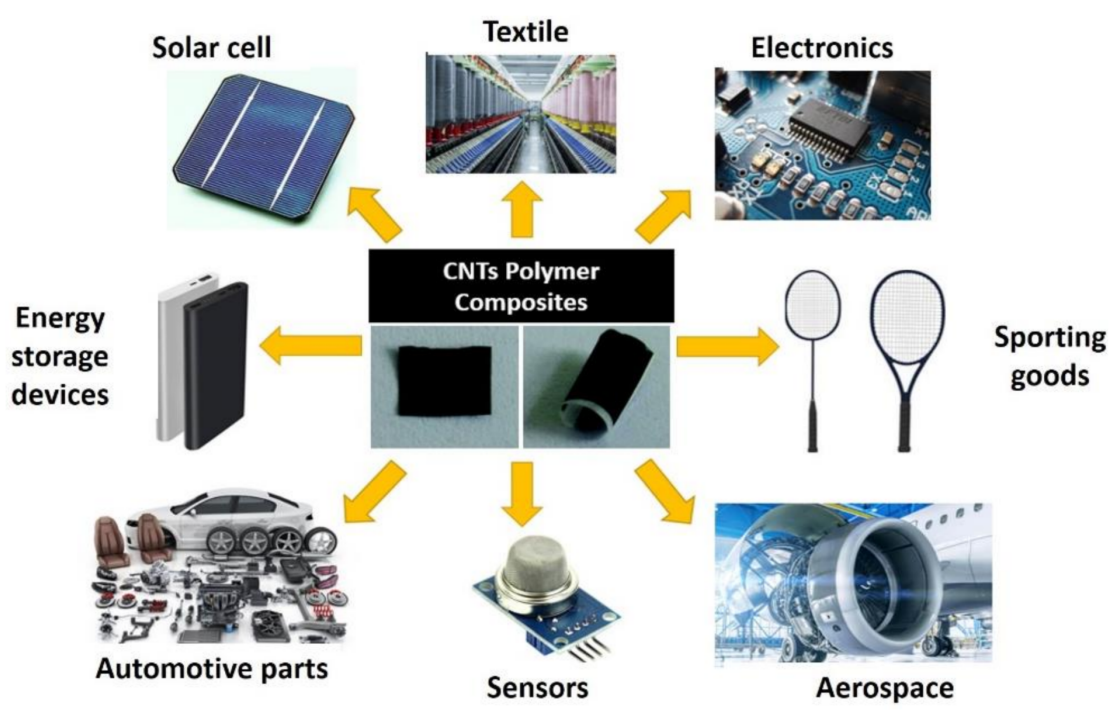

Figure 11. Application of CNT-polymer composites.

\subsection{Electronic Application}

The advanced applications of CNT-polymer composites are rising quickly in the electronic field, especially in the development in electronic devices. The growing demand for advanced materials with customize electrical properties makes CNTs the most attractive nanomaterials for electrical and electronic devices. The enhancement of field emission properties can result in the improvement of the efficiency of electronic devices. Connolly et al. (2009) [263] evaluated the field emission properties of CNT-polymer composites produced by solution processing. They found that an excellent electron emission could be obtained at a $0.7 \%$ volume fraction of nanotubes in a composite. The study also established that a good combination of the type of polymer and the concentration of CNT could improve the charge transfer through the composite. Likewise, research conducted by Jin et al. (2006) [264] showed that the triode-type field-emitting arrays could manufactured from CNT-reinforced PPy composites. They stated that CNT-PPy composite devices showed a better Fowler-Nordheim characteristic, which could potentially help their use in the semiconductor industry. More recent research conducted by Gupta et al. (2014) [265] found that the field emission properties of CNT/PPy nanocomposites were enhanced due to improvements of the electronic properties of PPy on the CNT layer, even when no dopant was added during the synthesis of PPy.

Additionally, CNT-polymer composites are useful when preparing solar cells. According to Sibinski et al. (2011) [266], elastic CNT-polymer composites have a high potential to produce new photovoltaics through a screen-printing technique. They discovered that the CNT-polymer composite had a high optical transmittance with less costly manufacturing process. The nanocomposite had a better elastic behavior and significantly strong optical and electrical parameters, which gives them potential use as coatings in solar cells.

\subsection{Aerospace Application}

The aerospace industry requires very high strength and durable materials to be embedded as components in astronautic equipment. Since CNTs has various characteristics, the materials have been widely studied to evaluate their potential to act as constituents of composite materials. The CNT-polymer composites are highly suitable for the aerospace and aeronautical fields. For the aerospace field, the CNT-polymer composites have been 
actively studied by researchers in order to enhance the electrical performance of composites with epoxy resin. Thus, CNT-polymer composites are essential in the aerospace field due to their structural properties that could be applied to such areas as in anti-radar protectors, antistatic materials, and spacecraft [267]. CNT-reinforced epoxy polymer composites have been commonly utilized in air/spacecraft developments since 2006. CNTs are emerging advanced materials that allow a structure to be lightweight, have elevated temperature resistance, and have high strength-to-weight ratio. Study by Kim et al. (2011) [268], tensile tests were conducted at $25 \%$ from their yield strength, and $4 \mathrm{wt} . \%$ CNT-reinforced polymer composites was discovered to break. In general, the $1 \mathrm{wt} . \%$ CNT composites doubled the Young's modulus and yield strength compared a pure epoxy laminate, as shown in Table 12.

Table 12. Yield strength and Young's modulus at different strain levels and CNT loading.

\begin{tabular}{cccc}
\hline CNTs (wt. \%) & $\boldsymbol{\sigma}_{\mathbf{1 0} \boldsymbol{*}} \mathbf{( M P a )}$ & Young's Modulus (MPa) & Yield Strength (MPa) \\
\hline 0 & 4 & $\mathrm{E}_{\mathrm{O}}=118$ & 1 \\
\hline 1 & 8 & $236\left(2 \times \mathrm{E}_{\mathrm{O}}\right)$ & 3 \\
\hline 4 & 10 & $456\left(3.9 \times \mathrm{E}_{\mathrm{O}}\right)$ & 6 \\
\hline
\end{tabular}

In accordance with the work of Belluci et al. (2007) [269], CNT-polymer composites can exhibit significant changes in their resistivity value, which is important for high-fidelity circuits in aerospace application. Additionally, the technology of electromagnetic interference (EMI) shielding was developed with CNT-PP composites by Al-Saleh and Sundararaj (2009) [270]. They indicated that the shielding from CNT-polymer composites provides absorption (major shielding mechanism) and reflection (secondary shielding mechanism). Moreover, the EMI shielding effectiveness of CNT-PP composites was elevated with increases in CNT content and shielding plate thickness, which showed the efficiency of the CNT nanocomposites. Next, CNT reinforced polymer composites could act as heat absorbing media that are useful in aerospace industries, e.g., as electromagnetic wave absorption materials [271].

\subsection{Automobile Application}

In the automotive sector, nanocomposite materials-especially CNT-polymer composites-could be beneficial in many ways, including the improvement of existing technologies. CNT reinforced polymer composites could be applied to automobile parts including exhaust systems, catalytic converters, suspension and breaking systems, electronic equipment, engines, power strain materials, and body parts [272,273]. Previously, traditional fillers such as mica, calcium carbonate, and talc were widely applied in automotive parts in order to offer higher melt viscosity, optical clarity, and better stiffness properties. For instance, glass fiber was introduced due to its high in stiffness, but it is difficult to fabricate and thus incurs high production costs. Additionally, traditional fillers and glass fibers have to be implemented with high loading to improve dimensional stability, increase the mechanical modulus, and increase surface quality. Thus, the introduction of CNT-polymer composites in this industry could aid the aforementioned issues of traditional fillers.

CNT fillers are effective at lower concentrations $(0.2 \mathrm{wt} . \%)$ in polymeric composites because they can significantly enhanced dimensional and thermal stability, as well as reduce weight $[259,274]$. CNT-polymer composites also play significant roles in automobile engineering. CNT-polymer composites have been found to possess a high strength-toweight ratio because a lightweight vehicle could allow for a vehicle to have a lower fuel consumption. This would result in the reduction of carbon dioxide emissions by the vehicle, which could help to reduce global warming. Yang et al. (2012) [275] discovered that a $25 \%$ reduction in vehicle weight would reduce crude barrel consumption by up to 250 million barrels per year. Many car manufacturing companies have employed nanocomposites in trunk lids, car seats, dashboard coverings, and roofs [276]. 
Furthermore, the addition of MWCNTs in epoxy composites would increase the adhesion strength of the matrix, which would subsequently contribute to lower water intake, hydrophobicity, and corrosion resistance [277]. Another study conducted by Lee et al. (2010) [278] found that the inclusion of CNTs and montmorillonite in epoxy resin would permit good anti-oxidation and flame retardant properties. These findings showed that CNT-reinforced rubber composites have a high potential to produce high-performance vehicle tires. According to Jia and Wei (2017) [279], the application of CNT rubber composites in tires would induce a high thermal conductivity and a low hysteresis. This would cause the tread base and shoulder parts to reduce the heat accumulation, which would subsequently prolong tire durability.

\subsection{Sensors}

CNT reinforced polymer composites have the significant ability to detect chemicals in the air for various purposes. Because they allow for the good ability to sense gas molecules, they would benefit space exploration; environmental monitoring; and medical, industrial and agricultural applications. For instance, the detection of carbon monoxide, nitrogen oxide, and ammonium is required to monitor environmental pollution in the industrial and medical environments. According to Kong et al. (2000) [280], individual SWCNT composites have been established in chemical sensor applications. It was discovered that the exposure to chemical molecules such as nitrogen oxide and ammonium of semi-conducting CNTs would provide changes in electrical resistance. Currently, electrical sensors implement carbon black polymer composites. This shows that the CNT-polymer composites could provide better and faster responses than current materials. Another study carried out by Sattari et al. (2014) [281] discovered that methane gas was efficiently sensed by CNT/polyaniline composites at room temperature. Likewise, Rajabi et al. (2013) [282] applied CNT/polyvinyl chloride (PVC) mixed matrix membranes for gas separation applications. Khan et al. (2014) [283] also established that similar nanocomposites that can function as indicator electrodes for titration of the potentiometric materials.

\subsection{Sporting Goods}

The promising values of CNT-polymer composites in this modern era have led many material scientists and engineers to conduct various studies in many study areas. One of the most stimulating characteristics of such composites are their light weight, high strength property, and strong stiffness property, which render them superlative fillers [284]. Due to the fact that CNT-polymer composites have high stiffness and strength values, the nanocomposites have been turned into structural products and applications such as civil engineering structures and sporting goods [285]. For superior composite sporting goods such as badminton rackets and golf sets, epoxy has been used to reinforce the CNT fillers. As such resins of this class have excellent specific strength, stiffness, chemical resistance, and dimensional stability $[232,235,237]$. However, there are still many challenges for CNTreinforced thermosetting polymer composites. These issues include the development of material features of nanocomposites when transferring the mechanical, thermal, and electrical properties of CNTs to epoxy composites [286].

\subsection{Wind Turbine Blades}

The renewable energy sector is currently growing rapidly to replace conventional energy such as coal and petroleum. One of fastest growing energy production sectors is wind energy. According to the US Department of Energy, the country aims to generate "green" energy as at least $20 \%$ of its total energy needs with wind-generated electricity by 2030. Thus, this industry intends to produce a high efficiency and optimum production of energy by generating large blades that are lighter in weight. This is due to the fact that the production of wind energy increases with the square-area of rotor radius $[287,288]$. The current goal in the field is to produce larger wind blades with good mechanical properties, light weight, and long fatigue life. However, this goal is huge challenge for 
many researchers as most lightweight, high strength, and high stiffness materials would have high costs in raw material and production.

In order to overcome this issue, a CNT-reinforced polymer matrix is potential material to be implemented in the production of wind blades. Based on previous studies, the application of CNT fillers as strengthening agents has highlighted the influence of CNTs on the stiffness and strength of composites. More recent research found that the inclusion of CNT fillers in composites could enhance fatigue resistance and subsequently prolong fatigue life [289]. Thus, many researchers are recently working on CNT-reinforced thermoset polymer composites in order to enhance tensile and fatigue properties for wind blade applications. In general, epoxy polymers are not suitable for the large scale production of wind blades because they have a shorter fatigue life and poorer fracture toughness. This, in turn, limits the operating life and reliability of wind blades in long term use. Thus, studies have to focus on the long-term prospective of CNT-polymer composites under cyclic loading to be utilized for structural applications that require an increased fatigue life.

According to Böger et al. (2010) [290], the inclusion of $0.2 \mathrm{wt}$.\% in epoxy polymer could enhance the fatigue resistance of composites. This could be done by dispersing the CNTs throughout epoxy resin with help from copolymers via sonication. Moreover, those tensile and dynamic mechanical properties were evaluated for pure epoxy and CNT-epoxy composites with five different load levels $(25,30,40,45$, and $50 \mathrm{MPa})$. At the end of the experiment, it was established that CNT/epoxy composites exhibited a long fatigue life and significant improvements of fatigue properties in high cycles. Moreover, the improvement in fatigue life occurred due to the pull-out of the CNTs and crack bridging at the crack interface, thus showing that CNT-reinforced polymer composites would be the most promising candidates with high fatigue lives to be used in major structural and dynamic applications.

\subsection{Environmental Remediation}

Globally, the increase in the pollution rate due to urbanization and industrialization has caused tremendous negative effects on environmental ecosystems [291,292]. Flora and fauna can be adversely affected by various types of contaminants such as chemical, physical, radiological, and biological contaminants [293]. Water contamination has become a worldwide problem over past few decades because of the disposal of contaminated waste in water systems. Preventative measures have to be implemented in order to reduce catastrophic effects on the environment.

In this case, the application of CNT-composites is one way to remedy excessive environmental pollution. CNTs have special adsorption capacities for different types of environmental pollutants by a large accessible external surface area, a high aspect ratio of fibrous shapes, and strong electrostatic interactions with charge pollutants in water [294]. In detail, CNTs can absorb pollutant particles on their external surfaces, open-ended portions, groves at the line boundary of carbon nanotube bundles, and the interstitial pores among the tube bundles [295]. It can be seen that CNTs have a good membrane separation ability that is especially useful for water treatment processes. CNT surface structures also have cytotoxic effects that inhibit the growth of microbes. Nanofillers have also been shown to contribute self-cleaning properties to CNT filters [296]. CNTs also considered to be good catalyzers for immobilized enzymes. In this case, immobilized enzymes on CNTs have shown more stability, broad $\mathrm{pH}$ ranges, more storage stability, better capacitive deionization, and more reusability. Yan et al. (2011) [297] successfully removed aniline aromatic compounds from water molecules by implementing immobilized enzymes of Delftia sp. XYJ6 on CNTs. Zhai et al. (2013) [298] showed that CNT-horseradish peroxidase enzyme could remove phenolic compounds from polluted water. Additionally, CNT-reinforced polymer membranes have a good ability for diffusivity, which makes them highly significant for water purification and adsorption systems for heavy metals ions, small molecules, organic chemicals, and radionuclides [299]. 


\section{The Economic Analysis of CNT Production}

The production of CNTs is anticipated to increase due to countless utilizations and applications in advanced nanotechnology. In 2018, the CNT market was estimated to grow from USD 4.55 billion to 9.84 billion by 2023 at a compound annual growth rate (CAGR) of $16.70 \%$. The growth of the CNT market is affected by the cost structure of CNTs, processing difficulties, and the availability of substitutes or specific functional groups such as silicon carbide nanotubes ( $\mathrm{SiCNTs}$ ). The methods that are used to produce carbon nanotubes, such as arc-discharge and laser ablation methods, are complex, expensive, hazardous for nature, and uneconomical for the production of CNTs on a large scale. The Asia Pacific Countries (APAC) carbon nanotubes market is expected to grow at the highest estimated CAGR during the forecast period. This is attributed to the robust demand for CNTs in India, China, South Korea, Vietnam, Taiwan, and Singapore; China is currently leading the demand for CNTs due to its increased industrial production, and it is largest consumer of CNTs at the global stage. The demand for CNTs has been rapidly increasing in applications such as field emission displays, integrated circuits, hydrogen storage, lithium (Li) batteries, solar photovoltaic (PV) cells, fuel cells, chemical sensors, and drug delivery. Increasing commercialization; the ramping up of installed capacities; and technological advancements to lowering the price, improve quality, and develop more advanced products are the trends in the CNT market. This includes in the demand for CNTs in the aerospace and automotive industries in order to make aerospace components stronger, tougher, and longer-lasting. The industry is attempting reduce weight in an ongoing bid to reduce fuel consumption and, by extension, operating costs. CNTs may be utilized in the aerospace and automotive industries for improved (or tailored) characteristics that improve their functional performance, especially their mechanical or electrical properties or those deliver multi-functional properties like light weight and conductivity. Furthermore, CNTs with distinct 1D-tubular structures, excellent electrical and thermal conductivities, and significantly large surface-areas are considered to be best nanomaterials to enhance Li battery performance. Li batteries are expected to have the highest market share during the forecast period from 2018 to 2023. The demand for Li-ion batteries is rapidly increasing in vehicles that require light weight and high-energy density solutions for batteries. These batteries provide the highest energy density per weight and are widely used in cellular phones, notebook computers, and hybrid automobiles [300].

\section{Conclusions and Future Outlooks}

The addition of CNTs to polymer composite structures with natural fiber has opened a new era of polymer composites for various structural applications. As polymer matrix reinforcements, different types of CNTs with specific and unique functional groups interact with hydroxyl groups in natural fiber cellulose chains, thus modifying the natural fiber surface. This might provide new promising interfacial bonding features. Definitely, among the applications related to CNT-based materials, the incorporation into natural fiber/fabric polymer composites has very recently attracted special attention for wide-ranging applications. Outstanding performance has justified the rapid increase in publications and has motivated attempts to develop engineering products. Indeed, from the aforesaid exponential growth, it is predicted that around 3000 articles on graphene-incorporated natural fiber polymer composites might be made by 2025 [301]. The incorporation of CNTs into polymer composites has been shown to significantly improve the strength, stiffness, toughness, electrical conductivity, and thermal stability of composites. Based on the articles discussed in this review, one should expect a promising future perspective for research works on the incorporation and functionalization of natural fibers with CNTs for a new generation of high-performance composites. Alternatively, there are relevant technological challenges to overcome, such as CTNs' reproducibility in large-scale applications, as well as their homogeneous dispersion in composites and their interfacial interactions. The safety, reliability, and durability of these composites are still subject to exploration. There is no hesitation that CNT hybrids with natural fiber polymer composites should promote 
pioneering research works and contribute to industrial developments, but more fundamental studies are needed to provide a better understanding of the interaction between components in this surging, novel class of polymer composite materials. From that, a prediction on the overall chemical interaction and response of bulk composites due to the existence of multiple interfaces (CNT/polymer interface, natural fiber/polymer interface, and CNT-modified natural fiber/polymer interface) requires the critical understanding and characterization of each individual interface in these advanced, multifunctional polymer composites through experimental and theoretical proofs. From the current reviewed applications, the hybridizing of CNTs with natural fiber has potential use in the automotive, aerospace, marine, and sporting goods industries.

Author Contributions: Conceptualization, N.M.N. and M.R.M.A.; validation, A.K., S.M.S. N.A., and M.R.I.; writing-original draft preparation, N.M.N., M.R.M.A., F.A.S., S.H.K., S.A., A.M.M., C.L.L., H.A.A., M.N.F.N., R.A.I., and M.M.H.; writing-review and editing, N.M.N., M.R.M.A., F.A.S., S.H.K., S.A., A.M.M., C.L.L., H.A.A., M.N.F.N., R.A.I., and M.M.H.; supervision, A.K., S.M.S. and N.A.; project administration, H.A.A.; funding acquisition, A.K. All authors have read and agreed to the published version of the manuscript.

Funding: This research was funded by Higher Education Center of Excellence (HICoE), Ministry of Higher Education, Malaysia (Grant number 6369109).

Institutional Review Board Statement: Not applicable.

Informed Consent Statement: Not applicable.

Data Availability Statement: Not applicable.

Acknowledgments: The authors would like to thank Universiti Putra Malaysia (UPM) for the technical and financial support. The authors also would like to thank Universiti Pertahanan Nasional Malaysia (UPNM) for understanding and technical support.

Conflicts of Interest: The authors declare no conflict of interest.

\section{References}

1. Iijima, S. Helical microtubules of graphitic carbon. Nature 1991, 354, 56-58. [CrossRef]

2. De, B.; Banerjee, S.; Verma, K.D.; Pal, T.; Manna, P.K.; Kar, K.K. Carbon nanotube as electrode materials for supercapacitors. In Springer Series in Materials Science; Springer: Berlin/Heidelberg, Germany, 2020; Volume 302, pp. $229-243$.

3. Ahmadi, M.; Zabihi, O.; Masoomi, M.; Naebe, M. Synergistic effect of MWCNTs functionalization on interfacial and mechanical properties of multi-scale UHMWPE fibre reinforced epoxy composites. Compos. Sci. Technol. 2016, 134, 1-11. [CrossRef]

4. Maruyama, B.; Alam, K. Carbon nanotubes and nanofibers in composite materials. SAMPE J. 2002, 38, 59-70.

5. Collins, P.G.; Avouris, P. Nanotubes for Electronics-Scientific American; Nature Publishing Group: San Francisco, CA, USA, 2000.

6. Song, H.J.; Zhang, Z.Z.; Men, X.H. Surface-modified carbon nanotubes and the effect of their addition on the tribological behavior of a polyurethane coating. Eur. Polym. J. 2007, 43, 4092-4102. [CrossRef]

7. Morsi, M.A.; Rajeh, A.; Al-Muntaser, A.A. Reinforcement of the optical, thermal and electrical properties of PEO based on MWCNTs/Au hybrid fillers: Nanodielectric materials for organoelectronic devices. Compos. Part B Eng. 2019, 173. [CrossRef]

8. Wu, Z.; Yang, Z.; Pei, K.; Qian, X.; Jin, C.; Che, R. Dandelion-like carbon nanotube assembly embedded with closely separated Co nanoparticles for high-performance microwave absorption materials. Nanoscale 2020, 12, 10149-10157. [CrossRef]

9. Mo, Z.; Yang, R.; Lu, D.; Yang, L.; Hu, Q.; Li, H.; Zhu, H.; Tang, Z.; Gui, X. Lightweight, three-dimensional carbon Nanotube@TiO 2 sponge with enhanced microwave absorption performance. Carbon N. Y. 2019, 144, 433-439. [CrossRef]

10. Souto, L.F.C.; Soares, B.G. Polyaniline/carbon nanotube hybrids modified with ionic liquids as anticorrosive additive in epoxy coatings. Prog. Org. Coat. 2020, 143. [CrossRef]

11. Hassan, A.G.; Yajid, M.A.M.; Saud, S.N.; Bakar, T.A.A.; Arshad, A.; Mazlan, N. Effects of varying electrodeposition voltages on surface morphology and corrosion behavior of multi-walled carbon nanotube coated on porous Ti-30 at.\%-Ta shape memory alloys. Surf. Coat. Technol. 2020, 401. [CrossRef]

12. Medupin, R.O.; Abubakre, O.K.; Abdulkareem, A.S.; Muriana, R.A.; Abdulrahman, A.S. Carbon Nanotube Reinforced Natural Rubber Nanocomposite for Anthropomorphic Prosthetic Foot Purpose. Sci. Rep. 2019, 9, 20146. [CrossRef] [PubMed]

13. Zainol Abidin, M.S.; Herceg, T.; Greenhalgh, E.S.; Shaffer, M.; Bismarck, A. Enhanced fracture toughness of hierarchical carbon nanotube reinforced carbon fibre epoxy composites with engineered matrix microstructure. Compos. Sci. Technol. 2019, 170, 85-92. [CrossRef]

14. Feng, D.; Xu, D.; Wang, Q.; Liu, P. Highly stretchable electromagnetic interference (EMI) shielding segregated polyurethane/carbon nanotube composites fabricated by microwave selective sintering. J. Mater. Chem. C 2019, 7, 7938-7946. [CrossRef] 
15. Zhou, E.; Xi, J.; Guo, Y.; Liu, Y.; Xu, Z.; Peng, L.; Gao, W.; Ying, J.; Chen, Z.; Gao, C. Synergistic effect of graphene and carbon nanotube for high-performance electromagnetic interference shielding films. Carbon N. Y. 2018, 133, 316-322. [CrossRef]

16. Chen, M.; Jing, Q.S.; Sun, H.B.; Xu, J.Q.; Yuan, Z.Y.; Ren, J.T.; Ding, A.X.; Huang, Z.Y.; Dong, M.Y. Engineering the Core-ShellStructured NCNTs-Ni2Si@Porous Si Composite with Robust Ni-Si Interfacial Bonding for High-Performance Li-Ion Batteries. Langmuir 2019, 35, 6321-6332. [CrossRef] [PubMed]

17. Guo, F.; Kang, T.; Liu, Z.; Tong, B.; Guo, L.; Wang, Y.; Liu, C.; Chen, X.; Zhao, Y.; Shen, Y.; et al. Advanced Lithium Metal-Carbon Nanotube Composite Anode for High-Performance Lithium-Oxygen Batteries. Nano Lett. 2019, 19, 6377-6384. [CrossRef] [PubMed]

18. Chen, M.; Wang, G.C.; Yang, W.Q.; Yuan, Z.Y.; Qian, X.; Xu, J.Q.; Huang, Z.Y.; Ding, A.X. Enhanced Synergetic Catalytic Effect of Mo2C/NCNTs@Co Heterostructures in Dye-Sensitized Solar Cells: Fine-Tuned Energy Level Alignment and Efficient Charge Transfer Behavior. ACS Appl. Mater. Interfaces 2019, 11, 42156-42171. [CrossRef] [PubMed]

19. Chen, M.; Wang, G.C.; Shao, L.L.; Yuan, Z.Y.; Qian, X.; Jing, Q.S.; Huang, Z.Y.; Xu, D.L.; Yang, S.X. Strategic Design of VacancyEnriched Fe1- xS Nanoparticles Anchored on Fe3C-Encapsulated and N-Doped Carbon Nanotube Hybrids for High-Efficiency Triiodide Reduction in Dye-Sensitized Solar Cells. ACS Appl. Mater. Interfaces 2018, 10, 31208-31224. [CrossRef]

20. Chen, M.; Zhao, G.; Shao, L.L.; Yuan, Z.Y.; Jing, Q.S.; Huang, K.J.; Huang, Z.Y.; Zhao, X.H.; Zou, G.D. Controlled Synthesis of Nickel Encapsulated into Nitrogen-Doped Carbon Nanotubes with Covalent Bonded Interfaces: The Structural and Electronic Modulation Strategy for an Efficient Electrocatalyst in Dye-Sensitized Solar Cells. Chem. Mater. 2017, 29, 9680-9694. [CrossRef]

21. Chen, M.; Shao, L.L.; Lv, X.W.; Wang, G.C.; Yang, W.Q.; Yuan, Z.Y.; Qian, X.; Han, Y.Y.; Ding, A.X. In situ growth of Niencapsulated and $\mathrm{N}$-doped carbon nanotubes on $\mathrm{N}$-doped ordered mesoporous carbon for high-efficiency triiodide reduction in dye-sensitized solar cells. Chem. Eng. J. 2020, 390. [CrossRef]

22. Janudin, N.; Abdullah, N.; Wan Yunus, W.M.Z.; Yasin, F.M.; Yaacob, M.H.; Mohamad Saidi, N.; Kasim, N.A.M. Effect of functionalized carbon nanotubes in the detection of benzene at room temperature. J. Nanotechnol. 2018, 2018. [CrossRef]

23. Maity, D.; Rajavel, K.; Kumar, R.T.R. Polyvinyl alcohol wrapped multiwall carbon nanotube (MWCNTs) network on fabrics for wearable room temperature ethanol sensor. Sens. Actuators B Chem. 2018, 261, 297-306. [CrossRef]

24. Nurazzi, N.M.; Harussani, M.M.; Siti Zulaikha, N.D.; Norhana, A.H.; Imran Syakir, M.; Norli, A. Composites based on conductive polymer with carbon nanotubes in DMMP gas sensors-An overview. Polimery 2021, 66, 85-97. [CrossRef]

25. Mananghaya, M.; Yu, D.; Santos, G.N.; Rodulfo, E. Scandium and Titanium Containing Single-Walled Carbon Nanotubes for Hydrogen Storage: A Thermodynamic and First Principle Calculation. Sci. Rep. 2016, 6, 27370. [CrossRef] [PubMed]

26. Yahya, M.S.; Ismail, M. Improvement of hydrogen storage properties of $\mathrm{MgH} 2$ catalyzed by $\mathrm{K} 2 \mathrm{NbF} 7$ and multiwall carbon nanotube. J. Phys. Chem. C 2018, 122, 11222-11233. [CrossRef]

27. Park, S.; Gupta, A.P.; Yeo, S.J.; Jung, J.; Paik, S.H.; Mativenga, M.; Kim, S.H.; Shin, J.H.; Ahn, J.S.; Ryu, J. Carbon nanotube field emitters synthesized on metal alloy substrate by PECVD for customized compact field emission devices to be used in X-ray source applications. Nanomaterials 2018, 8, 378. [CrossRef] [PubMed]

28. Song, Y.; Li, J.; Wu, Q.; Yi, C.; Wu, H.; Chen, Z.; Ou-Yang, W. Study of film thickness effect on carbon nanotube based field emission devices. J. Alloys Compd. 2020, 816. [CrossRef]

29. Kumar, R.; Ansari, M.O.; Barakat, M.A. DBSA doped polyaniline/multi-walled carbon nanotubes composite for high efficiency removal of $\mathrm{Cr}(\mathrm{VI})$ from aqueous solution. Chem. Eng. J. 2013, 228, 748-755. [CrossRef]

30. Xie, Y.; He, C.; Liu, L.; Mao, L.; Wang, K.; Huang, Q.; Liu, M.; Wan, Q.; Deng, F.; Huang, H.; et al. Carbon nanotube based polymer nanocomposites: Biomimic preparation and organic dye adsorption applications. RSC Adv. 2015, 5, 82503-82512. [CrossRef]

31. Peng-ChengMa, A.; Siddiquia, N.; Gad, M.; Jang-Kyo, K. Dispersion and functionalization of carbon nanotubes for polymer-based nanocomposites: A review. Compos. Part A Appl. Sci. Manuf. 2010, 41, 1345-1367.

32. Singh, N.P.; Gupta, V.K.; Singh, A.P. Graphene and carbon nanotube reinforced epoxy nanocomposites: A review. Polymer (Guildf). 2019, 180, 121724. [CrossRef]

33. Norizan, M.N.; Moklis, M.H.; Ngah Demon, S.Z.; Halim, N.A.; Samsuri, A.; Mohamad, I.S.; Knight, V.F.; Abdullah, N. Carbon nanotubes: Functionalisation and their application in chemical sensors. RSC Adv. 2020, 10, 43704-43732. [CrossRef]

34. Bahun, G.J.; Wang, C.; Adronov, A. Solubilizing single-walled carbon nanotubes with pyrene-functionalized block copolymers. J. Polym. Sci. Part A Polym. Chem. 2006, 44, 1941-1951. [CrossRef]

35. Khan, F.; Kausar, A.; Siddiq, M. A Review on Properties and Fabrication Techniques of Polymer/Carbon Nanotube Composites and Polymer Intercalated Buckypapers. Polym. Plast. Technol. Eng. 2015, 54, 1524-1539. [CrossRef]

36. Manawi, Y.M.; Ihsanullah, S.A.; Al-Ansari, T.; Atieh, M.A. A review of carbon nanomaterials' synthesis via the chemical vapor deposition (CVD) method. Materials 2018, 11, 822. [CrossRef] [PubMed]

37. Spitalsky, Z.; Tasis, D.; Papagelis, K.; Galiotis, C. Carbon nanotube-polymer composites: Chemistry, processing, mechanical and electrical properties. Prog. Polym. Sci. 2010, 35, 357-401. [CrossRef]

38. Chen, J.; Yan, L.; Song, W.; Xu, D. Interfacial characteristics of carbon nanotube-polymer composites: A review. Compos. Part A Appl. Sci. Manuf. 2018, 114, 149-169. [CrossRef]

39. Jacobs, C.B.; Peairs, M.J.; Venton, B.J. Review: Carbon nanotube based electrochemical sensors for biomolecules. Anal. Chim. Acta 2010, 662, 105-127. [CrossRef] [PubMed]

40. Zhao, Y.L.; Stoddart, J.F. Noncovalent functionalization of single-walled carbon nanotubes. Acconut Chem. Res. 2009, 42, 1161-1171. [CrossRef] 
41. Konnola, R.; Joseph, K. Effect of side-wall functionalisation of multi-walled carbon nanotubes on the thermo-mechanical properties of epoxy composites. RSC Adv. 2016, 6, 23887-23899. [CrossRef]

42. Maity, K.P.; Patra, A.; Prasad, V. Influence of the chemical functionalization of carbon nanotubes on low temperature ac conductivity with polyaniline composites. J. Phys. D. Appl. Phys. 2020, 53. [CrossRef]

43. Quintero-Jaime, A.F.; Cazorla-Amorós, D.; Morallón, E. Electrochemical functionalization of single wall carbon nanotubes with phosphorus and nitrogen species. Electrochim. Acta 2020,340. [CrossRef]

44. Nakonechna, O.I.; Belyavina, N.N.; Dashevskyi, M.M.; Ivanenko, K.O.; Revo, S.L. Novel Ti2CuCx and Ti3Cu2Cx Carbides Obtained by Sintering of Products of Mechanochemical Synthesis of Ti, Cu and Carbon Nanotubes. Phys. Chem. Solid State 2019, 19, 179-185. [CrossRef]

45. Garzia Trulli, M.; Sardella, E.; Palumbo, F.; Palazzo, G.; Giannossa, L.C.; Mangone, A.; Comparelli, R.; Musso, S.; Favia, P. Towards highly stable aqueous dispersions of multi-walled carbon nanotubes: The effect of oxygen plasma functionalization. J. Colloid Interface Sci. 2017, 491, 255-264. [CrossRef]

46. Singh, B.; Lohan, S.; Sandhu, P.S.; Jain, A.; Mehta, S.K. Functionalized carbon nanotubes and their promising applications in therapeutics and diagnostics. Nanobiomater. Med. Imaging Appl. Nanobiomater. 2016, 455-478. [CrossRef]

47. Ajori, S.; Ansari, R.; Darvizeh, M. Vibration characteristics of single- and double-walled carbon nanotubes functionalized with amide and amine groups. Phys. B Condens. Matter 2015, 462, 8-14. [CrossRef]

48. Afrin, R.; Shah, N.A. Room temperature gas sensors based on carboxyl and thiol functionalized carbon nanotubes buckypapers. Diam. Relat. Mater. 2015, 60, 42-49. [CrossRef]

49. Balasubramanian, K.; Burghard, M. Chemically Functionalized Carbon Nanotubes. Small 2005, 1, 180-192. [CrossRef]

50. Khan, M.U.; Gomes, V.G.; Altarawneh, I.S. Synthesizing polystyrene/carbon nanotube composites by emulsion polymerization with non-covalent and covalent functionalization. Carbon N. Y. 2010, 48, 2925-2933. [CrossRef]

51. Liu, X.; Xu, F.; Zhang, K.; Wei, B.; Gao, Z.; Qiu, Y. Characterization of enhanced interfacial bonding between epoxy and plasma functionalized carbon nanotube films. Compos. Sci. Technol. 2017, 145, 114-121. [CrossRef]

52. Li, Z.; Wang, L.; Li, Y.; Feng, Y.; Feng, W. Carbon-based functional nanomaterials: Preparation, properties and applications. Compos. Sci. Technol. 2019, 179, 10-40. [CrossRef]

53. Zhang, Y.; Huang, S. Significant improvements in the mechanical properties of chitosan functionalized carbon nanotubes/epoxy composites. RSC Adv. 2016, 6, 26210-26215. [CrossRef]

54. Fujigaya, T.; Nakashima, N. Non-covalent polymer wrapping of carbon nanotubes and the role of wrapped polymers as functional dispersants. Sci. Technol. Adv. Mater. 2015, 16. [CrossRef]

55. Alemour, B.; Yaacob, M.H.; Lim, H.N.; Hassan, M.R. Review of electrical properties of graphene conductive composites. Int. J. Nanoelectron. Mater. 2018, 11, 371-398.

56. Mallakpour, S.; Soltanian, S. Surface functionalization of carbon nanotubes: Fabrication and applications. RSC Adv. 2016, 6, 109916-109935. [CrossRef]

57. Janudin, N.; Abdullah, N.; Yunus, W.M.Z.W.; Yasin, F.M.; Yaacob, M.H.; Kasim, N.; Shah, N.A.A.; Jamal, S.H.; Saidi, N.M.; Kasim, N.A.M. Carbon nanofibers functionalized with amide group for ammonia gas detection. AIP Conf. Proc. 2019, 2068. [CrossRef]

58. Shamsuddin, S.A.; Derman, M.N.; Hashim, U.; Kashif, M.; Adam, T.; Halim, N.H.A.; Tahir, M.F.M. Nitric acid treated multi-walled carbon nanotubes optimized by Taguchi method. AIP Conf. Proc. 2016, 1756. [CrossRef]

59. Gonzalez-Chi, P.I.; Rodríguez-Uicab, O.; Martin-Barrera, C.; Uribe-Calderon, J.; Canché-Escamilla, G.; Yazdani-Pedram, M.; May-Pat, A.; Avilés, F. Influence of aramid fiber treatment and carbon nanotubes on the interfacial strength of polypropylene hierarchical composites. Compos. Part. B Eng. 2017, 122, 16-22. [CrossRef]

60. Zhang, T.; Xi, K.; Gu, M.; Jiang, Z.S. Phosphoryl choline-grafted water-soluble carbon nanotube. Chin. Chem. Lett. 2008, 19, 105-109. [CrossRef]

61. Dyke, C.A.; Tour, J.M. Covalent functionalization of single-walled carbon nanotubes for materials applications. J. Phys. Chem. A 2004, 108, 11151-11159. [CrossRef]

62. Jian, W.; Lau, D. Understanding the effect of functionalization in CNT-epoxy nanocomposite from molecular level. Compos. Sci. Technol. 2020, 191, 108076. [CrossRef]

63. Zou, W.; Du, Z.J.; Liu, Y.X.; Yang, X.; Li, H.Q.; Zhang, C. Functionalization of MWNTs using polyacryloyl chloride and the properties of CNT-epoxy matrix nanocomposites. Compos. Sci. Technol. 2008, 68, 3259-3264. [CrossRef]

64. Sydlik, S.A.; Lee, J.H.; Walish, J.J.; Thomas, E.L.; Swager, T.M. Epoxy functionalized multi-walled carbon nanotubes for improved adhesives. Carbon N. Y. 2013, 59, 109-120. [CrossRef]

65. Zhang, Q.; Wu, J.; Gao, L.; Liu, T.; Zhong, W.; Sui, G.; Zheng, G.; Fang, W.; Yang, X. Dispersion stability of functionalized MWCNT in the epoxy-amine system and its effects on mechanical and interfacial properties of carbon fiber composites. Mater. Des. 2016, 94, 392-402. [CrossRef]

66. Sapiai, N.; Jumahat, A.; Jawaid, M.; Khan, A. Effect of MWCNT surface functionalisation and distribution on compressive properties of kenaf and hybrid kenaf/glass fibres reinforced polymer composites. Polymers 2020, 12, 2522. [CrossRef] [PubMed]

67. Vaisman, L.; Wagner, H.D.; Marom, G. The role of surfactants in dispersion of carbon nanotubes. Adv. Colloid Interface Sci. 2006, 128-130, 37-46. [CrossRef]

68. Bilalis, P.; Katsigiannopoulos, D.; Avgeropoulos, A.; Sakellariou, G. Non-covalent functionalization of carbon nanotubes with polymers. RSC Adv. 2014, 4, 2911-2934. [CrossRef] 
69. Hertel, T.; Hagen, A.; Talalaev, V.; Arnold, K.; Hennrich, F.; Kappes, M.; Rosenthal, S.; McBride, J.; Ulbricht, H.; Flahaut, E. Spectroscopy of Single- and Double-Wall Carbon Nanotubes in Different Environments. Nano Lett. 2005, 5, 511-514. [CrossRef] [PubMed]

70. Dai, J.; Fernandes, R.M.F.; Regev, O.; Marques, E.F.; Furó, I. Dispersing Carbon Nanotubes in Water with Amphiphiles: Dispersant Adsorption, Kinetics, and Bundle Size Distribution as Defining Factors. J. Phys. Chem. C 2018, 122, 24386-24393. [CrossRef]

71. Ghoreishi, S.M.; Behpour, M.; Mousavi, S.; Khoobi, A.; Ghoreishi, F.S. Simultaneous electrochemical determination of dopamine, ascorbic acid and uric acid in the presence of sodium dodecyl sulphate using a multi-walled carbon nanotube modified carbon paste electrode. RSC Adv. 2014, 4, 37979-37984. [CrossRef]

72. Kharisov, B.I.; Kharissova, O.V.; Dimas, A.V. The dispersion, solubilization and stabilization in "solution" of single-walled carbon nanotubes. RSC Adv. 2016, 6, 68760-68787. [CrossRef]

73. Zeng, X.; Yang, D.; Liu, H.; Zhou, N.; Wang, Y.; Zhou, W.; Xie, S.; Kataura, H. Detecting and Tuning the Interactions between Surfactants and Carbon Nanotubes for Their High-Efficiency Structure Separation. Adv. Mater. Interfaces 2018, 5. [CrossRef]

74. Manilo, M.V.; Lebovka, N.; Barany, S. Combined effect of cetyltrimethylammonium bromide and laponite platelets on colloidal stability of carbon nanotubes in aqueous suspensions. J. Mol. Liq. 2017, 235, 104-110. [CrossRef]

75. Park, M.; Park, J.; Lee, J.; Ju, S.Y. Scaling of binding affinities and cooperativities of surfactants on carbon nanotubes. Carbon N. Y. 2018, 139, 427-436. [CrossRef]

76. Ishibashi, A.; Nakashima, N. Strong chemical structure dependence for individual dissolution of single-walled carbon nanotubes in aqueous micelles of biosurfactants. Bull. Chem. Soc. Jpn. 2006, 79, 357-359. [CrossRef]

77. Chen, Y.; Wei, W.; Zhu, Y.; Luo, J.; Liu, X. Noncovalent functionalization of carbon nanotubes via co-deposition of tannic acid and polyethyleneimine for reinforcement and conductivity improvement in epoxy composite. Compos. Sci. Technol. 2019, 170, 25-33. [CrossRef]

78. Du, A.-K.; Yang, K.-L.; Zhao, T.-H.; Wang, M.; Zeng, J.-B. Poly(sodium 4-styrenesulfonate) wrapped carbon nanotube with low percolation threshold in poly( $\varepsilon$-caprolactone) nanocomposites. Polym. Test. 2016, 51, 40-48. [CrossRef]

79. Cha, J.; Jin, S.; Shim, J.H.; Park, C.S.; Ryu, H.J.; Hong, S.H. Functionalization of carbon nanotubes for fabrication of CNT/epoxy nanocomposites. Mater. Des. 2016, 95, 1-8. [CrossRef]

80. Zhang, A.; Luan, J.; Zheng, Y.; Sun, L.; Tang, M. Effect of percolation on the electrical conductivity of amino molecules noncovalently coated multi-walled carbon nanotubes/epoxy composites. Appl. Surf. Sci. 2012, 258, 8492-8497. [CrossRef]

81. Gupta, T.K.; Kumar, S. 4-Fabrication of Carbon Nanotube/Polymer Nanocomposites. In Carbon Nanotube-Reinforced Polymers; Rafie, R., Ed.; Elsevier: Amsterdam, The Netherlands, 2018; pp. 61-81. [CrossRef]

82. Papageorgiou, D.G.; Li, Z.; Liu, M.; Kinloch, I.A.; Young, R.J. Mechanisms of mechanical reinforcement by graphene and carbon nanotubes in polymer nanocomposites. Nanoscale 2020, 12, 2228-2267. [CrossRef]

83. Rane, A.V.; Kanny, K.; Abitha, V.K.; Thomas, S. Methods for Synthesis of Nanoparticles and Fabrication of Nanocomposites. Synth. Inorg. Nanomater. 2018, 121-139. [CrossRef]

84. Venkataraman, A.; Amadi, E.V.; Chen, Y.; Papadopoulos, C. Carbon Nanotube Assembly and Integration for Applications. Nanoscale Res. Lett. 2019, 14, 220. [CrossRef]

85. Yousfi, M.; Alix, S.; Lebeau, M.; Soulestin, J.; Lacrampe, M.F.; Krawczak, P. Evaluation of rheological properties of non-Newtonian fluids in micro rheology compounder: Experimental procedures for a reliable polymer melt viscosity measurement. Polym. Test. 2014, 40. [CrossRef]

86. Balachandra, A.M.; Corporation, T.; Co, M.; Darsanasiri, N.; Corporation, M. Fabrication of Carbonnanotube/Polymer Nanocomposite Sheets and Its Mechanical Performance. Adv. Nanosci. Nanotechnol. 2018, 2. [CrossRef]

87. Cheng, F.; Imin, P.; Maunders, C.; Botton, G.; Adronov, A. Soluble, discrete supramolecular complexes of single-walled carbon nanotubes with fluorene-based conjugated polymers. Macromolecules 2008, 41, 2304-2308. [CrossRef]

88. Pei, X.; Hu, L.; Liu, W.; Hao, J. Synthesis of water-soluble carbon nanotubes via surface initiated redox polymerization and their tribological properties as water-based lubricant additive. Eur. Polym. J. 2008, 44, 2458-2464. [CrossRef]

89. Kanoun, O.; Bouhamed, A.; Ramalingame, R.; Bautista-Quijano, J.R.; Rajendran, D.; Al-Hamry, A. Review review on conductive polymer/cnts nanocomposites based flexible and stretchable strain and pressure sensors. Sensors 2021, 21, 341. [CrossRef] [PubMed]

90. Khan, W.; Sharma, R.; Saini, P. Carbon nanotube-based polymer composites: Synthesis, properties and applications. In Carbon Nanotubes Current Progress of their Polymer Composites; IntechOpen: London, UK, 2016. [CrossRef]

91. Bryning, M.B.; Milkie, D.E.; Islam, M.F.; Kikkawa, J.M.; Yodh, A.G.; Bryning, M.B.; Milkie, D.E.; Islam, M.F.; Kikkawa, J.M.; Yodh, A.G. Thermal conductivity and interfacial resistance in single-wall carbon nanotube epoxy composites. Appl. Phys. Lett. 2005, 87, 161909. [CrossRef]

92. Barrau, S.; Demont, P.; Perez, E.; Peigney, A.; Laurent, C.; Lacabanne, C. Effect of palmitic acid on the electrical conductivity of carbon nanotubes-Epoxy resin composites. Macromolecules 2003, 36, 9678-9680. [CrossRef]

93. Islam, M.F.; Rojas, E.; Bergey, D.M.; Johnson, A.T.; Yodh, A.G. High weight fraction surfactant solubilization of single-wall carbon nanotubes in water. Nano Lett. 2003, 3, 269-273. [CrossRef]

94. Arrigo, R.; Teresi, R.; Gambarotti, C.; Parisi, F.; Lazzara, G.; Dintcheva, N.T. Sonication-induced modification of carbon nanotubes: Effect on the rheological and thermo-oxidative behaviour of polymer-based nanocomposites. Materials 2018, 11, 383. [CrossRef] 
95. Sabet, S.M.; Mahfuz, H.; Hashemi, J.; Nezakat, M.; Szpunar, J.A. Effects of sonication energy on the dispersion of carbon nanotubes in a vinyl ester matrix and associated thermo-mechanical properties. J. Mater. Sci. 2015, 50, 4729-4740. [CrossRef]

96. Korayem, A.H.; Barati, M.R.; Chen, S.J.; Simon, G.P.; Zhao, X.L.; Duan, W.H. Optimizing the degree of carbon nanotube dispersion in a solvent for producing reinforced epoxy matrices. Powder Technol. 2015, 284, 541-550. [CrossRef]

97. Santos, A.C.M.Q.S.; Monticeli, F.M.; Ornaghi, H.; de Santos, L.F.P.; Cioffi, M.O.H. Porosity characterization and respective influence on short-beam strength of advanced composite processed by resin transfer molding and compression molding. Polym. Polym. Compos. 2020, 1-10. [CrossRef]

98. Ali, M.A.; Umer, R.; Khan, K.A.; Samad, Y.A. Graphene coated smart fabrics for vartm process monitoring. ICCM Int. Conf. Compos. Mater. 2017.

99. Cheng, Q.F.; Wang, J.P.; Wen, J.J.; Liu, C.H.; Jiang, K.L.; Li, Q.Q.; Fan, S.S. Carbon nanotube/epoxy composites fabricated by resin transfer molding. Carbon N. Y. 2010, 48, 260-266. [CrossRef]

100. Trakakis, G.; Tomara, G.; Datsyuk, V.; Sygellou, L.; Bakolas, A.; Tasis, D.; Parthenios, J.; Krontiras, C.; Georga, S.; Galiotis, C.; et al. Mechanical, electrical, and thermal properties of carbon nanotube buckypapers/epoxy nanocomposites produced by oxidized and epoxidized nanotubes. Materials 2020, 13, 4308. [CrossRef] [PubMed]

101. Teotia, S.; Singh, B.P.; Elizabeth, I.; Singh, V.N.; Ravikumar, R.; Singh, A.P.; Gopukumar, S.; Dhawan, S.K.; Srivastava, A.; Mathur, R.B. Multifunctional, robust, light-weight, free-standing MWCNT/phenolic composite paper as anodes for lithium ion batteries and EMI shielding material. RSC Adv. 2014, 4, 33168-33174. [CrossRef]

102. Ogasawara, T.; Moon, S.Y.; Inoue, Y.; Shimamura, Y. Mechanical properties of aligned multi-walled carbon nanotube/epoxy composites processed using a hot-melt prepreg method. Compos. Sci. Technol. 2011, 71, 1826-1833. [CrossRef]

103. Bradford, P.D.; Wang, X.; Zhao, H.; Maria, J.P.; Jia, Q.; Zhu, Y.T. A novel approach to fabricate high volume fraction nanocomposites with long aligned carbon nanotubes. Compos. Sci. Technol. 2010, 70, 1980-1985. [CrossRef]

104. Jiang, Q.; Wang, X.; Zhu, Y.; Hui, D.; Qiu, Y. Mechanical, electrical and thermal properties of aligned carbon nanotube/polyimide composites. Compos. Part. B Eng. 2014, 56, 408-412. [CrossRef]

105. Wang, X.; Yong, Z.Z.; Li, Q.W.; Bradford, P.D.; Liu, W.; Tucker, D.S.; Cai, W.; Wang, H.; Yuan, F.G.; Zhu, Y.T. Ultrastrong, stiff and multifunctional carbon nanotube composites. Mater. Res. Lett. 2013, 1, 19-25. [CrossRef]

106. Nam, T.H.; Goto, K.; Yamaguchi, Y.; Premalal, E.V.A.; Shimamura, Y.; Inoue, Y.; Arikawa, S.; Yoneyama, S.; Ogihara, S. Improving mechanical properties of high volume fraction aligned multi-walled carbon nanotube/epoxy composites by stretching and pressing. Compos. Part. B Eng. 2016, 85, 15-23. [CrossRef]

107. Nam, T.H.; Goto, K.; Oshima, K.; Premalal, E.V.A.; Shimamura, Y.; Inoue, Y.; Naito, K.; Ogihara, S. Mechanical property enhancement of aligned multi-walled carbon nanotube sheets and composites through press-drawing process. Adv. Compos. Mater. 2016, 25, 73-86. [CrossRef]

108. Nam, T.H.; Goto, K.; Yamaguchi, Y.; Premalal, E.V.A.; Shimamura, Y.; Inoue, Y.; Naito, K.; Ogihara, S. Effects of CNT diameter on mechanical properties of aligned CNT sheets and composites. Compos. Part. A Appl. Sci. Manuf. 2015, 76, 289-298. [CrossRef]

109. Geim, A.K.; Novoselov, K.S. The rise of graphene. Nanosci. Technol. A Collect. Rev. Nat. J. 2009, 11-19. [CrossRef]

110. Verma, D.; Goh, K.L. Functionalized graphene-based nanocomposites for energy applications. In Functionalized Graphene Nanocomposites and Their Derivatives: Synthesis, Processing and Applications; Elsevier: Amsterdam, The Netherlands, 2018; pp. 219-243. ISBN 9780128145531.

111. Chatterjee, S.; Wang, J.W.; Kuo, W.S.; Tai, N.H.; Salzmann, C.; Li, W.L.; Hollertz, R.; Nüesch, F.A.; Chu, B.T.T. Mechanical reinforcement and thermal conductivity in expanded graphene nanoplatelets reinforced epoxy composites. Chem. Phys. Lett. 2012, 531, 6-10. [CrossRef]

112. Kaminsky, W. Polyolefin-nanocomposites with special properties by in-situ polymerization. Front. Chem. Sci. Eng. 2018, 12, 555-563. [CrossRef]

113. Yoo, H.J.; Jung, Y.C.; Sahoo, N.G.; Cho, J.W. Polyurethane-carbon nanotube nanocomposites prepared by in-situ polymerization with electroactive shape memory. J. Macromol. Sci. Part. B Phys. 2006, 45, 441-451. [CrossRef]

114. Martin, D.J.; Osman, A.F.; Andriani, Y.; Edwards, G.A. Thermoplastic Polyurethane (TPU)-Based Polymer Nanocomposites. In Advances in Polymer Nanocomposites; Gao, F., Ed.; Woodhead Publishing Limited: Sawston, UK, 2012; ISBN 9781845699406.

115. Xia, H.; Wang, Q.; Qiu, G. Polymer-encapsulated carbon nanotubes prepared through ultrasonically initiated in situ emulsion polymerization. Chem. Mater. 2003, 15, 3879-3886. [CrossRef]

116. Ke, K.; Wang, Y.; Liu, X.Q.; Cao, J.; Luo, Y.; Yang, W.; Xie, B.H.; Yang, M.B. A comparison of melt and solution mixing on the dispersion of carbon nanotubes in a poly(vinylidene fluoride) matrix. Compos. Part. B Eng. 2012, 43, 1425-1432. [CrossRef]

117. Wu, M.L.; Chen, Y.; Zhang, L.; Zhan, H.; Qiang, L.; Wang, J.N. High-performance carbon nanotube/polymer composite fiber from layer-by-layer deposition. ACS Appl. Mater. Interfaces 2016, 8, 8137-8144. [CrossRef] [PubMed]

118. Al-Saleh, M.H.; Al-Anid, H.K.; Hussain, Y.A. CNT/ABS nanocomposites by solution processing: Proper dispersion and selective localization for low percolation threshold. Compos. Part. A Appl. Sci. Manuf. 2013, 46, 53-59. [CrossRef]

119. Meitl, M.A.; Zhou, Y.; Gaur, A.; Jeon, S.; Usrey, M.L.; Strano, M.S.; Rogers, J.A. Solution casting and transfer printing single-walled carbon nanotube films. Nano Lett. 2004, 4, 1643-1647. [CrossRef]

120. Du, J.H.; Bai, J.; Cheng, H.M. The present status and key problems of carbon nanotube based polymer composites. Express Polym. Lett. 2007, 1, 253-273. [CrossRef] 
121. Huang, Y.Y.; Terentjev, E.M. Dispersion of carbon nanotubes: Mixing, sonication, stabilization, and composite properties. Polymers 2012, 4, 275-295. [CrossRef]

122. Montazeri, A.; Montazeri, N.; Pourshamsian, K.; Tcharkhtchi, A. The effect of sonication time and dispersing medium on the mechanical properties of multiwalled carbon nanotube (MWCNT)/epoxy composite. Int. J. Polym. Anal. Charact. 2011, 16, 465-476. [CrossRef]

123. Byrne, M.T.; Guin'Ko, Y.K. Recent advances in research on carbon nanotube-Polymer composites. Adv. Mater. 2010, 22, 1672-1688. [CrossRef] [PubMed]

124. Wang, Z.; Liang, Z.; Wang, B.; Zhang, C.; Kramer, L. Processing and property investigation of single-walled carbon nanotube (SWNT) buckypaper/epoxy resin matrix nanocomposites. Compos. Part. A Appl. Sci. Manuf. 2004, 35, 1225-1232. [CrossRef]

125. Feng, Q.P.; Yang, J.P.; Fu, S.Y.; Mai, Y.W. Synthesis of carbon nanotube/epoxy composite films with a high nanotube loading by a mixed-curing-agent assisted layer-by-layer method and their electrical conductivity. Carbon N. Y. 2010, 48, 2057-2062. [CrossRef]

126. Cheng, Q.; Bao, J.; Park, J.G.; Liang, Z.; Zhang, C.; Wang, B. High mechanical performance composite conductor: Multi-walled carbon nanotube sheet/bismaleimide nanocomposites. Adv. Funct. Mater. 2009, 19, 3219-3225. [CrossRef]

127. Nam, T.H.; Goto, K.; Nakayama, H.; Oshima, K.; Premalal, V.; Shimamura, Y.; Inoue, Y.; Naito, K.; Kobayashi, S. Effects of stretching on mechanical properties of aligned multi-walled carbon nanotube/epoxy composites. Compos. Part A Appl. Sci. Manuf. 2014, 64, 194-202. [CrossRef]

128. Wang, X.; Bradford, P.D.; Liu, W.; Zhao, H.; Inoue, Y.; Maria, J.P.; Li, Q.; Yuan, F.G.; Zhu, Y. Mechanical and electrical property improvement in CNT/Nylon composites through drawing and stretching. Compos. Sci. Technol. 2011, 71, 1677-1683. [CrossRef]

129. Park, S.; Ruoff, R.S. Chemical methods for the production of graphenes. Nat. Nanotechnol. 2009, 4, 217-224. [CrossRef]

130. Kim, S.; Fornasiero, F.; Park, H.G.; In, J.B.; Meshot, E.; Giraldo, G.; Stadermann, M.; Fireman, M.; Shan, J.; Grigoropoulos, C.P.; et al. Fabrication of flexible, aligned carbon nanotube/polymer composite membranes by in-situ polymerization. J. Membr. Sci. 2014, 460, 91-98. [CrossRef]

131. Cho, B.G.; Lee, J.E.; Hwang, S.H.; Han, J.H.; Chae, H.G.; Park, Y. Bin Enhancement in mechanical properties of polyamide 66-carbon fiber composites containing graphene oxide-carbon nanotube hybrid nanofillers synthesized through in situ interfacial polymerization. Compos. Part. A Appl. Sci. Manuf. 2020, 135, 105938. [CrossRef]

132. Park, D.W.; Shim, S. A review on thermal conductivity of polymer composites using carbon-based fillers: Carbon nanotubes and carbon fibers. Carbon Lett. 2010, 11, 347-356.

133. Zhang, J.; Zou, H.; Qing, Q.; Yang, Y.; Li, Q.; Liu, Z.; Guo, X.; Du, Z. Effect of chemical oxidation on the structure of single-walled carbon nanotubes. J. Phys. Chem. B 2003, 107, 3712-3718. [CrossRef]

134. Lourie, O.; Wagner, H.D. Evaluation of Young's modulus of carbon nanotubes by micro-Raman spectroscopy. J. Mater. Res. 1998, 13, 2418-2422. [CrossRef]

135. Lau, K.T.; Gu, C.; Hui, D. A critical review on nanotube and nanotube/nanoclay related polymer composite materials. Compos. Part B Eng. 2006, 37, 425-436. [CrossRef]

136. Wernik, J.M.; Meguid, S.A. On the mechanical characterization of carbon nanotube reinforced epoxy adhesives. Mater. Des. 2014, 59, 19-32. [CrossRef]

137. Coleman, J.N.; Khan, U.; Blau, W.J.; Gun'ko, Y.K. Small but strong: A review of the mechanical properties of carbon nanotubepolymer composites. Carbon N. Y. 2006, 44, 1624-1652. [CrossRef]

138. Zhu, H.W.; Xu, C.L.; Wu, D.H.; Wei, B.Q.; Vajtai, R.; Ajayan, P.M. Direct synthesis of long single-walled carbon nanotube strands. Science 2002, 296, 884-886. [CrossRef]

139. Daniel, I.M.; Ishai, O.; Daniel, I.M.; Daniel, I. Engineering Mechanics of Composite Materials; Oxford University Press: Oxford, UK, 2006.

140. Fredriksson, T. Carbon Nanotubes: A Theoretical Study of Young's Modulus. Master's Thesis, Karlstad University; Faculty of Health, Science and Technology, Karlstad, Sweden, 2014.

141. Gardea, F.; Lagoudas, D.C. Characterization of electrical and thermal properties of carbon nanotube/epoxy composites. Compos. Part B Eng. 2014, 56, 611-620. [CrossRef]

142. Sankar, N.; Reddy, M.N.; Prasad, R.K. Carbon nanotubes dispersed polymer nanocomposites: Mechanical, electrical, thermal properties and surface morphology. Bull. Mater. Sci. 2016, 39, 47-55. [CrossRef]

143. Thostenson, E.T.; Li, C.; Chou, T.W. Nanocomposites in context. Compos. Sci. Technol. 2005, 65, 491-516. [CrossRef]

144. Hassan, M.A. Physicaland Thermal Properties of Fiber (S-Type)-Reinforced Compositearaldite Resin (GY 260). Al-Qadisiyah J. Eng. Sci. 2012, 5, 341-346.

145. Marulanda, J.M. Carbon Nanotubes: Applications on Electron Devices. IntechOpen: London, UK, 2011.

146. Mazumdar, S. Composites Manufacturing: Materials, Product, and Process Engineering; CRC Press: Boca Raton, FA, USA, 2001.

147. Arash, B.; Wang, Q.; Varadan, V.K. Mechanical properties of carbon nanotube/polymer composites. Sci. Rep. 2014, 4, 1-8. [CrossRef] [PubMed]

148. Coleman, J.N.; Khan, U.; Gun'ko, Y.K. Mechanical reinforcement of polymers using carbon nanotubes. Adv. Mater. 2006, 18, 689-706. [CrossRef]

149. Manchado, M.L.; Valentini, L.; Biagiotti, J.; Kenny, J.M. Thermal and mechanical properties of single-walled carbon nanotubespolypropylene composites prepared by melt processing. Carbon N. Y. 2005, 43, 1499-1505. [CrossRef] 
150. Deep, A.; Singh, K.K.; Rawat, P.; Kumar, C.; Behera, R.P. Impact of hybrid reinforcement (nano-and macro-) over quasi-isotropic symmetrically designed GFRP composites on short beam strength properties. IOP Conf. Ser. Mater. Sci. Eng. 2018, $377,012166$. [CrossRef]

151. Jia, Z.; Wang, Z.; Xu, C.; Liang, J.; Wei, B.; Wu, D.; Zhu, S. Study on poly (methyl methacrylate)/carbon nanotube composites. Mater. Sci. Eng. A 1999, 271, 395-400. [CrossRef]

152. Yang, M.; Gao, Y.; Li, H.; Adronov, A. Functionalization of multiwalled carbon nanotubes with polyamide 6 by anionic ringopening polymerization. Carbon N. Y. 2007, 45, 2327-2333. [CrossRef]

153. Kearns, J.C.; Shambaugh, R.L. Polypropylene fibers reinforced with carbon nanotubes. J. Appl. Polym. Sci. 2002, 86, 2079-2084. [CrossRef]

154. Siochi, E.J.; Working, D.C.; Park, C.; Lillehei, P.T.; Rouse, J.H.; Topping, C.C.; Bhattacharyya, A.R.; Kumar, S. Melt processing of SWCNT-polyimide nanocomposite fibers. Compos. Part B Eng. 2004, 35, 439-446. [CrossRef]

155. Shi, D.; Lian, J.; He, P.; Wang, L.M.; Xiao, F.; Yang, L.; Schulz, M.J.; Mast, D.B. Plasma coating of carbon nanofibers for enhanced dispersion and interfacial bonding in polymer composites. Appl. Phys. Lett. 2003, 83, 5301-5303. [CrossRef]

156. Lou, X.; Detrembleur, C.; Sciannamea, V.; Pagnoulle, C.; Jérôme, R. Grafting of alkoxyamine end-capped (co) polymers onto multi-walled carbon nanotubes. Polymer 2004, 45, 6097-6102. [CrossRef]

157. Xie, L.; Xu, F.; Qiu, F.; Lu, H.; Yang, Y. Single-walled carbon nanotubes functionalized with high bonding density of polymer layers and enhanced mechanical properties of composites. Macromolecules 2007, 40, 3296-3305. [CrossRef]

158. Hasanzadeh, M.; Mottaghitalab, V.; Ansari, R.; Moghadam, B.H.; Haghi, A.K. Issues in production of carbon nanotubes and related nanocomposites: A comprehensive review. Cell. Chem. Technol. 2015, 49, 237-257.

159. Choi, E.Y.; Kim, J.Y.; Kim, C.K. Fabrication and properties of polycarbonate composites with polycarbonate grafted multi-walled carbon nanotubes by reactive extrusion. Polymer 2015, 60, 18-25. [CrossRef]

160. Xiang, D.; Harkin-Jones, E.; Linton, D.; Martin, P. Structure, mechanical, and electrical properties of high-density polyethylene/multi-walled carbon nanotube composites processed by compression molding and blown film extrusion. J. Appl. Polym. Sci. 2015, 132, 1-12. [CrossRef]

161. Verma, P.; Saini, P.; Choudhary, V. Designing of carbon nanotube/polymer composites using melt recirculation approach: Effect of aspect ratio on mechanical, electrical and EMI shielding response. Mater. Des. 2015, 88, 269-277. [CrossRef]

162. Alam, J.; Khan, A.; Alam, M.; Mohan, R. Electroactive shape memory property of a Cu-decorated CNT dispersed PLA/ESO nanocomposite. Materials 2015, 8, 6391-6400. [CrossRef] [PubMed]

163. Mei, H.; Xia, J.; Han, D.; Xiao, S.; Deng, J.; Cheng, L. Dramatic increase in electrical conductivity in epoxy composites with uni-directionally oriented laminae of carbon nanotubes. Chem. Eng. J. 2016, 304, 970-976. [CrossRef]

164. Shamsi, R.; Mahyari, M.; Koosha, M. Synthesis of CNT-polyurethane nanocomposites using ester-based polyols with different molecular structure: Mechanical, thermal, and electrical properties. J. Appl. Polym. Sci. 2017, 134, 1-13. [CrossRef]

165. Deplancke, T.; Lame, O.; Barrau, S.; Ravi, K.; Dalmas, F. Impact of carbon nanotube prelocalization on the ultra-low electrical percolation threshold and on the mechanical behavior of sintered UHMWPE-based nanocomposites. Polymer 2017, 111, 204-213. [CrossRef]

166. Hajializadeh, S.; Barikani, M.; Bellah, S.M. Synthesis and characterization of multiwall carbon nanotube/waterborne polyurethane nanocomposites. Polym. Int. 2017, 66, 1074-1083. [CrossRef]

167. Martinez-Rubi, Y.; Ashrafi, B.; Jakubinek, M.B.; Zou, S.; Laqua, K.; Barnes, M.; Simard, B. Fabrication of High Content Carbon Nanotube-Polyurethane Sheets with Tailorable Properties. ACS Appl. Mater. Interfaces 2017, 9, 30840-30849. [CrossRef] [PubMed]

168. Yakovlev, Y.V.; Gagolkina, Z.O.; Lobko, E.V.; Khalakhan, I.; Klepko, V.V. The effect of catalyst addition on the structure, electrical and mechanical properties of the cross-linked polyurethane/carbon nanotube composites. Compos. Sci. Technol. 2017, 144, 208-214. [CrossRef]

169. Ibrahim, S.S.; Ayesh, A.S.; Abdel-Rahem, R.A. Investigation on the physical properties of multiwalled carbon nanotubepolystyrene nanocomposites treated with 2, 3-hydroxy-2-naphthoic acid. J. Thermoplast. Compos. Mater. 2017, 30, 1120-1135. [CrossRef]

170. Kalakonda, P.; Banne, S. Thermomechanical properties of PMMA and modified SWCNT composites. Nanotechnol. Sci. Appl. 2017, 10, 45-52. [CrossRef] [PubMed]

171. Hawkins, S.A.; Yao, H.; Wang, H.; Sue, H.J. Tensile properties and electrical conductivity of epoxy composite thin films containing zinc oxide quantum dots and multi-walled carbon nanotubes. Carbon N. Y. 2017, 115, 18-27. [CrossRef]

172. Wu, H.Y.; Jia, L.C.; Yan, D.X.; Gao, J.F.; Zhang, X.P.; Ren, P.G.; Li, Z.M. Simultaneously improved electromagnetic interference shielding and mechanical performance of segregated carbon nanotube/polypropylene composite via solid phase molding. Compos. Sci. Technol. 2018, 156, 87-94. [CrossRef]

173. Behera, R.P.; Rawat, P.; Singh, K.K. Tensile behavior of three phased glass/epoxy laminate embedded with MWCNTs: An experimental approach. Mater. Today Proc. 2018, 5, 8176-8183. [CrossRef]

174. Kumar, C.; Singh, K.K.; Rawat, P.; Deep, A.; Behera, R.P. Effect of loading rate on inter laminar shear strength (ILSS) of highly doped MWCNTs carbon/epoxy laminates. IOP Conf. Ser. Mater. Sci. Eng. 2018, 455, 012006. [CrossRef]

175. Singh, K.K.; Rawat, P. Mechanical behavior of glass/epoxy composite laminate with varying amount of MWCNTs under different loadings. Mater. Res. Express 2018, 5, 055012. [CrossRef] 
176. Namasivayam, M.; Shapter, J. Factors affecting carbon nanotube fillers towards enhancement of thermal conductivity in polymer nanocomposites: A review. J. Compos. Mater. 2017, 51, 3657-3668. [CrossRef]

177. Chen, J.; Liu, B.; Gao, X.; Xu, D. A review of the interfacial characteristics of polymer nanocomposites containing carbon nanotubes. RSC Adv. 2018, 8, 28048-28085. [CrossRef]

178. Huang, C.; Qian, X.; Yang, R. Thermal conductivity of polymers and polymer nanocomposites. Mater. Sci. Eng. R Rep. 2018, 132, 1-22. [CrossRef]

179. Chen, H.; Ginzburg, V.V.; Yang, J.; Yang, Y.; Liu, W.; Huang, Y.; Du, L.; Chen, B. Thermal conductivity of polymer-based composites: Fundamentals and applications. Prog. Polym. Sci. 2016, 59, 41-85. [CrossRef]

180. Ma, J.; Zhang, Q.; Mayo, A.; Ni, Z.; Yi, H.; Chen, Y.; Mu, R.; Bellan, L.M.; Li, D. Thermal conductivity of electrospun polyethylene nanofibers. Nanoscale 2015, 7, 16899-16908. [CrossRef]

181. Smith, M.K.; Bougher, T.L.; Kalaitzidou, K.; Cola, B.A. Melt-processed P3HT and PE Polymer Nanofiber Thermal Conductivity. MRS Adv. 2017, 2, 3619-3626. [CrossRef]

182. Lu, C.; Chiang, S.W.; Du, H.; Li, J.; Gan, L.; Zhang, X.; Chu, X.; Yao, Y.; Li, B.; Kang, F. Thermal conductivity of electrospinning chain-aligned polyethylene oxide (PEO). Polymer 2017, 115, 52-59. [CrossRef]

183. Burger, N.; Laachachi, A.; Ferriol, M.; Lutz, M.; Toniazzo, V.; Ruch, D. Review of thermal conductivity in composites: Mechanisms, parameters and theory. Prog. Polym. Sci. 2016, 61,1-28. [CrossRef]

184. Wang, G.; Wang, L.; Mark, L.H.; Shaayegan, V.; Wang, G.; Li, H.; Zhao, G.; Park, C.B. Ultralow-Threshold and Lightweight Biodegradable Porous PLA/MWCNT with Segregated Conductive Networks for High-Performance Thermal Insulation and Electromagnetic Interference Shielding Applications. ACS Appl. Mater. Interfaces 2018, 10, 1195-1203. [CrossRef]

185. Ngo, I.L.; Jeon, S.; Byon, C. Thermal conductivity of transparent and flexible polymers containing fillers: A literature review. Int. J. Heat Mass Transf. 2016, 98, 219-226. [CrossRef]

186. Gong, P.; Wang, G.; Tran, M.P.; Buahom, P.; Zhai, S.; Li, G.; Park, C.B. Advanced bimodal polystyrene/multi-walled carbon nanotube nanocomposite foams for thermal insulation. Carbon N. Y. 2017, 120, 1-10. [CrossRef]

187. Guo, H.; Liu, J.; Wang, Q.; Liu, M.; Du, C.; Li, B.; Feng, L. High thermal conductive poly(vinylidene fluoride)-based composites with well-dispersed carbon nanotubes/graphene three-dimensional network structure via reduced interfacial thermal resistance Compos. Sci. Technol. 2019, 181, 107713. [CrossRef]

188. Kim, H.S.; Jang, J.U.; Yu, J.; Kim, S.Y. Thermal conductivity of polymer composites based on the length of multi-walled carbon nanotubes. Compos. Part B Eng. 2015, 79, 505-512. [CrossRef]

189. Eslami, Z.; Yazdani, F.; Mirzapour, M.A. Thermal and mechanical properties of phenolic-based composites reinforced by carbon fibres and multiwall carbon nanotubes. Compos. Part A Appl. Sci. Manuf. 2015, 72, 22-31. [CrossRef]

190. Jackson, E.M.; Laibinis, P.E.; Collins, W.E.; Ueda, A.; Wingard, C.D.; Penn, B. Development and thermal properties of carbon nanotube-polymer composites. Compos. Part B Eng. 2016, 89, 362-373. [CrossRef]

191. Kamarian, S.; Bodaghi, M.; Isfahani, R.B.; Shakeri, M.; Yas, M.H. Influence of carbon nanotubes on thermal expansion coefficient and thermal buckling of polymer composite plates: Experimental and numerical investigations. Mech. Based Des. Struct. Mach. 2019, 42, 1-16. [CrossRef]

192. Das, S.; Kumar, A.; Parida, K.; Choudhary, R.N.P.; Roy, A. Electrical and mechanical behavior of PMN-PT / CNT based polymer composite film for energy harvesting. Appl. Surf. Sci. 2018, 428, 356-363. [CrossRef]

193. Zhang, L.; Li, X.; Deng, H.; Jing, Y.; Fu, Q. Enhanced thermal conductivity and electrical insulation properties of polymer composites via constructing Pglass/CNTs con fi ned hybrid fi llers. Compos. Part A Appl. Sci. Manuf. 2018, 115, 1-7. [CrossRef]

194. Dydek, K.; Latko-durałek, P.; Boczkowska, A.; Sałaciński, M.; Kozera, R. Carbon Fiber Reinforced Polymers modified with thermoplastic nonwovens containing multi-walled carbon nanotubes. Compos. Sci. Technol. 2019, 173, 110-117. [CrossRef]

195. Wang Y., W. G.J. Electrical Conductivity of Carbon Nanotube- and Graphene-Based Nanocomposites. In Micromechanics and Nanomechanics of Composite Solids; Springer: Cham, Switzerland, 2018; pp. 123-156.

196. Sobha, A.P.; Sreekala, P.S.; Narayanankutty, S.K. Electrical, thermal, mechanical and electromagnetic interference shielding properties of PANI/FMWCNT/TPU composites. Prog. Org. Coat. 2017, 113, 168-174. [CrossRef]

197. Gupta, P.; Rajput, M.; Singla, N.; Kumar, V.; Lahiri, D. Electric fi eld and current assisted alignment of CNT inside polymer matrix and its effects on electrical and mechanical properties. Polymer 2016, 89, 119-127. [CrossRef]

198. Nguyen Thi, T.B.; Ata, S.; Morimoto, T.; Yamada, T.; Okazaki, T.; Hata, K. Tailoring the electrically conductive network of injection-molded polymer-carbon nanotube composite at low filler content. Mater. Today Proc. 2020, in press. [CrossRef]

199. Haghgoo, M.; Ansari, R.; Hassanzadeh-Aghdam, M.K. Prediction of electrical conductivity of carbon fiber-carbon nanotubereinforced polymer hybrid composites. Compos. Part B Eng. 2019, 167, 728-735. [CrossRef]

200. Chen, J.; Han, J. Effect of hydroxylated carbon nanotubes on the thermal and electrical properties of derived epoxy composite materials. Results Phys. 2020, 18. [CrossRef]

201. Matos, M.A.S.; Tagarielli, V.L.; Pinho, S.T. On the electrical conductivity of composites with a polymeric matrix and a non-uniform concentration of carbon nanotubes. Compos. Sci. Technol. 2020, 188. [CrossRef]

202. Wang, S.; Huang, Y.; Chang, E.; Zhao, C.; Ameli, A.; Naguib, H.E.; Park, C.B. Evaluation and modeling of electrical conductivity in conductive polymer nanocomposite foams with multiwalled carbon nanotube networks. Chem. Eng. J. 2021, 411. [CrossRef]

203. Mora, A.; Han, F.; Lubineau, G. Estimating and understanding the e ffi ciency of nanoparticles in enhancing the conductivity of carbon nanotube / polymer composites. Results Phys. 2018, 10, 81-90. [CrossRef] 
204. Doh, J.; Yang, Q.; Raghavan, N. Reliability-based robust design optimization of polymer nanocomposites to enhance percolated electrical conductivity considering correlated input variables using multivariate distributions. Polymer 2020, 186. [CrossRef]

205. Weiya, Z.; Wenjun, M.A.; Zhiqiang, N.I.U.; Li, S.; Sishen, X.I.E. Freestanding single-walled carbon nanotube bundle networks: Fabrication, properties and composites. Chin. Sci. Bull. 2012, 57, 205-224. [CrossRef]

206. Afiqah, N.; Radzuan, M.; Bakar, A.; Sahari, J. A review of electrical conductivity models for conductive polymer composite. Int. J. Hydrogen Energy 2016, 2. [CrossRef]

207. Nabilah, A.; Yusuf, M.; Bakar, A.; Sahari, J. The effect of milled carbon fi bre fi ller on electrical conductivity in highly conductive polymer composites. Compos. Part B Eng. 2017, 110, 153-160.

208. Xiaojuan, N.; Chao, H.; Ninghai, S.W.J.F.L. Monte Carlo simulations of electrical percolation in multicomponent thin films with nanofillers. Nanotechnology 2018, 29. [CrossRef]

209. Gao, J.; Wang, H.; Huang, X.; Hu, M.; Xue, H.; Li, R.K.Y. Electrically conductive polymer nano fi ber composite with an ultralow percolation threshold for chemical vapour sensing. Compos. Sci. Technol. 2018, 161, 135-142. [CrossRef]

210. Zhai, W.; Zhao, S.; Wang, Y.; Zheng, G.; Dai, K.; Liu, C.; Shen, C. Segregated conductive polymer composite with synergistically electrical and mechanical properties. Compos. Part A 2018, 105, 68-77. [CrossRef]

211. Yamamoto, T.; Kawaguchi, K. Synthesis and Electrical Properties of Composite Films Comprising Polymer Particles and Carbon Nanotubes. Colloid Interface Sci. Commun. 2017, 20, 5-8. [CrossRef]

212. Xia, Q.; Mei, H.; Zhang, Z.; Liu, Y.; Liu, Y.; Leng, J. Fabrication of the silver modified carbon nanotube film/carbon fiber reinforced polymer composite for the lightning strike protection application. Compos. Part B Eng. 2020, 180. [CrossRef]

213. Khan, T.; Irfan, M.S.; Ali, M.; Dong, Y.; Ramakrishna, S.; Umer, R. Insights to low electrical percolation thresholds of carbon-based polypropylene nanocomposites. Carbon 2021, 176, 602-631. [CrossRef]

214. Imtiaz, S.; Siddiq, M.; Kausar, A.; Tul, S.; Ambreen, J.; Bibi, I. A Review Featuring Fabrication, Properties and Applications of Carbon Nanotubes ( CNTs ) Reinforced Polymer and Epoxy Nanocomposites. Chin. J. Polym. Sci. 2018, 36, 445-461. [CrossRef]

215. Yuan, S.; Zheng, Y.; Chua, C.K.; Yan, Q.; Zhou, K. Electrical and thermal conductivities of MWCNT/polymer composites fabricated by selective laser sintering. Compos. Part A Appl. Sci. Manuf. 2018, 105. [CrossRef]

216. Saheeda, P.; Jayaleksmi, S. Liquid/liquid interfacial polymerization as an effective synthesis approach for polypyrrole/MWCNTs nanocomposite with impressive nonlinear optical properties. Opt. Mater. 2020, 104. [CrossRef]

217. Zhang, H.; Zhang, G.; Tang, M.; Zhou, L.; Li, J.; Fan, X.; Shi, X.; Qin, J. Synergistic effect of carbon nanotube and graphene nanoplates on the mechanical, electrical and electromagnetic interference shielding properties of polymer composites and polymer composite foams. Chem. Eng. J. 2018, 353, 381-393. [CrossRef]

218. Burmistrov, I.; Gorshkov, N.; Ilinykh, I.; Muratov, D.; Kolesnikov, E.; Anshin, S. Improvement of carbon black based polymer composite electrical conductivity with additions of MWCNT. Compos. Sci. Technol. 2016, 129, 79-85. [CrossRef]

219. Qu, S.; Yao, Q.; Wang, L.; Hua, J.; Chen, L. A novel hydrophilic pyridinium salt polymer/SWCNTs composite fi lm for high thermoelectric performance. Polymer 2018, 136, 149-156. [CrossRef]

220. Avilés, F.; May-pat, A.; López-manchado, M.A.; Verdejo, R.; Bachmatiuk, A. A comparative study on the mechanical, electrical and piezoresistive properties of polymer composites using carbon nanostructures of di ff erent topology. Eur. Polym. J. 2018, 99, 394-402. [CrossRef]

221. Francis, A.P.; Devasena, T. Toxicity of carbon nanotubes: A review. Toxicol. Ind. Health 2018, 34, 200-210. [CrossRef] [PubMed]

222. Chen, K.L.; Smith, B.A.; Ball, W.P.; Fairbrother, D.H. Assessing the colloidal properties of engineered nanoparticles in water: Case studies from fullerene C60 nanoparticles and carbon nanotubes. Environ. Chem. 2010, 7, 10-27. [CrossRef]

223. Sousa, S.P.; Baptista, J.S.; Ribeiro, M. Polymer nano and submicro composites risk assessment. Int. J. Work. Cond. 2014, 7, 103-119.

224. Chen, T.; Nie, H.; Gao, X.; Yang, J.; Pu, J. Epithelial-mesenchymal transition involved in pulmonary fibrosis induced by multi-walled carbon nanotubes via TGFbeta/ Smad signaling pathway. Toxicol. Lett. 2014, 226, 150-162. [CrossRef] [PubMed]

225. Sohaebuddin, S.K.; Thevenot, P.T.; Baker, D.; Eaton, J.W.; Tang, L. Nanomaterial cytotoxicity is composition, size, and cell type dependent. Part Fibre Toxicol. 2010, 7. [CrossRef]

226. Boyles, M.S.; Young, L.; Brown, D.M.; MacCalman, L.; Cowie, H.; Moisala, A.; Smail, F.; Smith, P.J.; Proudfoot, L.; Windle, A.H.; et al. Multi-walled carbon nanotube induced frustrated phagocytosis, cytotoxicity and pro-inflammatory conditions in macrophages are length dependent and greater than that of asbestos. Toxicol. Vitr. 2015, 29, 1513-1528. [CrossRef] [PubMed]

227. Kim, J.E.; Lim, H.T.; Minai-Tehrani, A.; Kwon, J.T.; Shin, J.Y.; Woo, C.G.; Choi, M.; Baek, J.; Jeong, D.H.; Ha, Y.C.; et al. Toxicity and clearance of intratracheally administered multiwalled carbon nanotubes from murine lung. J. Toxicol. Environ. Health Part $A$ 2010, 73, 1530-1543. [CrossRef]

228. Heister, E.; Brunner, E.W.; Dieckmann, G.R.; Jurewicz, I.; Dalton, A.B. Are carbon nanotubes a natural solution? Applications in biology and medicine. ACS Appl. Mater. Interfaces 2013, 5, 1870-1891. [CrossRef] [PubMed]

229. Shvedova, A.A.; Kisin, E.R.; Murray, A.R.; Gorelik, O.; Arepalli, S.; Castranova, V.; Young, S.H.; Gao, F.; Tyurina, Y.Y.; Oury, T.D.; et al. Vitamin E deficiency enhances pulmonary inflammatory response and oxidative stress induced by single-walled carbon nanotubes in C57BL/6 mice. Toxicol. Appl. Pharmacol. 2007, 221, 339-348. [CrossRef]

230. Facciolà, A.; Visalli, G.; La Maestra, S.; Ceccarelli, M.; D’Aleo, F.; Nunnari, G.; Pellicanò, G.F.; Di Pietro, A. Carbon nanotubes and central nervous system: Environmental risks, toxicological aspects and future perspectives. Environ. Toxicol. Pharmacol. 2019, 65, 23-30. [CrossRef] 
231. Fleury, D.; Bomfim, J.A.; Vignes, A.; Girard, C.; Metz, S.; Muñoz, F.; R'Mili, B.; Ustache, A.; Guiot, A.; Bouillard, J.X. Identification of the main exposure scenarios in the production of CNT-polymer nanocomposites by melt-moulding process. J. Clean. Prod. 2013, 53, 22-36. [CrossRef]

232. Johari, A.N.; Ishak, M.R.; Leman, Z.; Yusoff, M.Z.M.; Asyraf, M.R.M. Creep behaviour monitoring of short-term duration for fiber-glass reinforced composite cross-arms with unsaturated polyester resin samples using conventional analysis. J. Mech. Eng. Sci. 2020, 14, 7361-7368. [CrossRef]

233. Asyraf, M.R.M.; Ishak, M.R.; Sapuan, S.M.; Yidris, N.; Rafidah, M.; Ilyas, R.A.; Razman, M.R. Potential application of green composites for cross arm component in transmission tower: A brief review. Int. J. Polym. Sci. 2020. [CrossRef]

234. Omran, A.A.B.; Mohammed, A.A.B.A.; Sapuan, S.M.; Ilyas, R.A.; Asyraf, M.R.M.; Koloor, S.S.R.; Petrů, M. Micro- and Nanocellulose in Polymer Composite Materials: A Review. Polymers 2021, 13, 231. [CrossRef] [PubMed]

235. Johari, A.N.; Ishak, M.R.; Leman, Z.; Yusoff, M.Z.M.; Asyraf, M.R.M. Influence of CaCO3 in pultruded glass fibre/unsaturated polyester composite on flexural creep behaviour using conventional and TTSP methods. Polimery 2020, 65, 46-54. [CrossRef]

236. Asyraf, M.R.M.; Rafidah, M.; Ishak, M.R.; Sapuan, S.M.; Yidris, N.; Ilyas, R.A.; Razman, M.R. Integration of TRIZ, Morphological Chart and ANP method for development of FRP composite portable fire extinguisher. Polym. Compos. 2020, 41, $2917-2932$. [CrossRef]

237. Asyraf, M.R.M.; Ishak, M.R.; Sapuan, S.M.; Yidris, N.; Ilyas, R.A. Woods and composites cantilever beam: A comprehensive review of experimental and numerical creep methodologies. J. Mater. Res. Technol. 2020, 9, 6759-6776. [CrossRef]

238. Asyraf, M.R.M.; Ishak, M.R.; Sapuan, S.M.; Yidris, N.; Shahroze, R.M.; Johari, A.N.; Rafidah, M.; Ilyas, R.A. Creep test rig for cantilever beam: Fundamentals, prospects and present views. J. Mech. Eng. Sci. 2020, 14, 6869-6887. [CrossRef]

239. Ilyas, R.; Sapuan, S.; Atikah, M.; Asyraf, M.; Rafiqah, S.A.; Aisyah, H.; Nurazzi, N.M.; Norrrahim, M. Effect of hydrolysis time on the morphological, physical, chemical, and thermal behavior of sugar palm nanocrystalline cellulose (Arenga pinnata (Wurmb.) Merr). Text. Res. J. 2021, 91, 152-167. [CrossRef]

240. Asyraf, M.R.M.; Ishak, M.R.; Sapuan, S.M.; Yidris, N. Utilization of Bracing Arms as Additional Reinforcement in Pultruded Glass Fiber-Reinforced Polymer Composite Cross-Arms: Creep Experimental and Numerical Analyses. Polymers 2021, 13, 620. [CrossRef]

241. Alsubari, S.; Zuhri, M.Y.M.; Sapuan, S.M.; Ishak, M.R.; Ilyas, R.A.; Asyraf, M.R.M. Potential of Natural Fiber Reinforced Polymer Composites in Sandwich Structures: A Review on Its Mechanical Properties. Polymers 2021, 13, 423. [CrossRef]

242. Asyraf, M.R.M.; Rafidah, M.; Azrina, A.; Razman, M.R. Dynamic mechanical behaviour of kenaf cellulosic fibre biocomposites: A comprehensive review on chemical treatments. Cellulose 2021, 1-21. [CrossRef]

243. Nurazzi, N.M.; Asyraf, M.R.M.; Khalina, A.; Abdullah, N.; Aisyah, H.A.; Rafiqah, S.A.; Sabaruddin, F.A.; Kamarudin, M.N.F.; Ilyas, R.A.; Sapuan, S.M. A Review on Natural Fiber Reinforced Polymer Composite for Bullet Proof and Ballistic Applications. Polymers 2021, 13, 646. [CrossRef] [PubMed]

244. Ilyas, R.A.; Sapuan, S.M.; Atiqah, A.; Ibrahim, R.; Abral, H.; Ishak, M.R.; Zainudin, E.S.; Nurazzi, N.M.; Atikah, M.S.N.; Ansari, M.N.M.; et al. Sugar palm (Arenga pinnata [Wurmb.] Merr) starch films containing sugar palm nanofibrillated cellulose as reinforcement: Water barrier properties. Polym. Compos. 2020, 41. [CrossRef]

245. Ilyas, R.A.; Sapuan, S.M.; Asyraf, M.R.M.; Atikah, M.S.N.; Ibrahim, R.; Dele-Afolabia, T.T. Introduction to biofiller reinforced degradable polymer composites. In Biofiller Reinforced Biodegradable Polymer Composites; Sapuan, S.M., Jumaidin, R., Hanafi, I., Eds.; CRC Press: Boca Raton, FL, USA, 2020; pp. 1-23.

246. Ilyas, R.A.; Sapuan, S.M.; Norrrahim, M.N.F.; Yasim-Anuar, T.A.T.; Kadier, A.; Kalil, M.S.; Atikah, M.S.N.; Ibrahim, R.; Asrofi, M.; Abral, H.; et al. Nanocellulose/starch biopolymer nanocomposites: Processing, manufacturing, and applications. In Advanced Processing, Properties, and Applications of Starch and Other Bio-Based Polymers; Al-Oqla, F.M., Sapuan, S.M., Eds.; Elsevier Inc.: Amsterdam, The Netherlands, 2020; pp. 65-88.

247. Asyraf, M.R.M.; Ishak, M.R.; Sapuan, S.M.; Yidris, N. Influence of Additional Bracing Arms as Reinforcement Members in Wooden Timber Cross-Arms on Their Long-Term Creep Responses and Properties. Appl. Sci. 2021, 11, 2061. [CrossRef]

248. Asyraf, M.R.M.; Ishak, M.R.; Razman, M.R.; Chandrasekar, M. Fundamentals of creep, testing methods and development of test rig for the full-scale crossarm: A review. J. Teknol. 2019, 81, 155-164. [CrossRef]

249. Amal, M.K.E.; Mahmoud, M.F. Carbon nanotube reinforced composites: Potential and current challenges. Mater. Des. 2007, 28, 2394-2401.

250. Lau, A.K.T.; Hui, D. The revolutionary creation of new advanced materials-Carbon nanotube composites. Compos. Part B Eng. 2002, 33, 263-277. [CrossRef]

251. Asyraf, M.R.M.; Ishak, M.R.; Sapuan, S.M.; Yidris, N.; Ilyas, R.A.; Rafidah, M.; Razman, M.R. Evaluation of Design and Simulation of Creep Test Rig for Full-Scale Crossarm Structure. Adv. Civ. Eng. 2020, 2020. [CrossRef]

252. Asyraf, M.R.M.; Ishak, M.R.; Sapuan, S.M.; Yidris, N. Conceptual design of multi-operation outdoor flexural creep test rig using hybrid concurrent engineering approach. J. Mater. Res. Technol. 2020, 9, 2357-2368. [CrossRef]

253. Asyraf, M.R.M.; Ishak, M.R.; Sapuan, S.M.; Yidris, N. Conceptual design of creep testing rig for full-scale cross arm using TRIZ-Morphological chart-analytic network process technique. J. Mater. Res. Technol. 2019, 8, 5647-5658. [CrossRef]

254. Frackowiak, E.; Khomenko, V.; Jurewicz, K.; Lota, K.; Béguin, F. Supercapacitors based on conducting polymers/nanotubes composites. J. Power Sources 2006, 153, 413-418. [CrossRef] 
255. Dai, C.A.; Hsiao, C.C.; Weng, S.C.; Kao, A.C.; Liu, C.P.; Tsai, W.B.; Chen, W.S.; Liu, W.M.; Shih, W.P.; Ma, C.C. A membrane actuator based on an ionic polymer network and carbon nanotubes: The synergy of ionic transport and mechanical properties. Smart Mater. Struct. 2009, 18. [CrossRef]

256. Jancar, J. Impact behavior of a short glass fiber reinforced thermoplastic polyurethane. Polym. Compos. 2000, 21, 369-376. [CrossRef]

257. Meincke, O.; Kaempfer, D.; Weickmann, H.; Friedrich, C.; Vathauer, M.; Warth, H. Mechanical properties and electrical conductivity of carbon-nanotube filled polyamide- 6 and its blends with acrylonitrile/butadiene/styrene. Polymer 2004, 45, 739-748. [CrossRef]

258. Köhler, A.R.; Som, C.; Helland, A.; Gottschalk, F. Studying the potential release of carbon nanotubes throughout the application life cycle. J. Clean. Prod. 2008, 16, 927-937. [CrossRef]

259. Kingston, C.; Zepp, R.; Andrady, A.; Boverhof, D.; Fehir, R.; Hawkins, D.; Roberts, J.; Sayre, P.; Shelton, B.; Sultan, Y.; et al. Release characteristics of selected carbon nanotube polymer composites. Carbon N. Y. 2014, 68, 33-57. [CrossRef]

260. Mittal, G.; Dhand, V.; Rhee, K.Y.; Park, S.J.; Lee, W.R. A review on carbon nanotubes and graphene as fillers in reinforced polymer nanocomposites. J. Ind. Eng. Chem. 2015, 21, 11-25. [CrossRef]

261. Thostenson, T.E.; Ren, Z.; Chou, T.W. Advances in the science and technology of carbon nanotubes and their composites: A review. Compos. Sci. Technol. 2001, 61, 1899-1912. [CrossRef]

262. Breuer, O.; Sundararaj, U. Big returns from small fibers: A review of polymer/carbon nanotube composites. Polym. Compos. 2004, 25, 630-645. [CrossRef]

263. Connolly, T.; Smith, R.C.; Hernandez, Y.; Gun'ko, Y.; Coleman, J.C.; Carey, J.D. Carbon-nanotube-polymer nanocomposites for field-emission cathodes. Small 2009, 5, 826-831. [CrossRef]

264. Li, S.Y.; Lee, C.Y.; Lin, P.; Tseng, T.Y. Gate-controlled ZnO nanowires for field-emission device application. J. Vac. Sci. Technol. B Microelectron. Nanomater. Struct. 2006, 24, 147. [CrossRef]

265. Gupta, N.D.; Maity, S.; Chattopadhyay, K.K. Field emission enhancement of polypyrrole due to band bending induced tunnelling in polypyrrole-carbon nanotubes nanocomposite. J. Ind. Eng. Chem. 2014, 20, 3208-3213. [CrossRef]

266. Sibiński, M.; Jakubowska, M.; Znajdek, K.; Słoma, M.; Guzowski, B. Carbon nanotube transparent conductive layers for solar cells applications. Opt. Appl. 2011, 41,375-381.

267. Joshi, M.; Chatterjee, U. Polymer nanocomposite: An advanced material for aerospace applications. Adv. Compos. Mater. Aerosp. Eng. 2016, 241-264.

268. Kim, M.T.; Rhee, K.Y.; Lee, J.H.; Hui, D.; Lau, A.K.T. Property enhancement of a carbon fiber/epoxy composite by using carbon nanotubes. Compos. Part B Eng. 2011, 42, 1257-1261. [CrossRef]

269. Bellucci, S.; Balasubramanian, C.; Micciulla, F.; Rinaldi, G. CNT composites for aerospace applications. J. Exp. Nanosci. 2007, 2, 193-206. [CrossRef]

270. Al-Saleh, M.H.; Sundararaj, U. Electromagnetic interference shielding mechanisms of CNT/polymer composites. Carbon N. Y. 2009, 47, 1738-1746. [CrossRef]

271. Kim, Y.Y.; Yun, J.; Kim, H.I.; Lee, Y.S. Effect of oxyfluorination on electromagnetic interference shielding of polypyrrole-coated multi-walled carbon nanotubes. J. Ind. Eng. Chem. 2012, 18, 392-398. [CrossRef]

272. Zhang, D.; Villarreal, M.G.; Cabrera, E.; Benatar, A.; James Lee, L.; Castro, J.M. Performance study of ultrasonic assisted processing of CNT nanopaper/solventless epoxy composite. Compos. Part B Eng. 2019, 159, 327-335. [CrossRef]

273. Ilyas, R.A.; Sapuan, M.S.; Norizan, M.N.; Norrrahim, M.N.F.; Ibrahim, R.; Atikah, M.S.N.; Huzaifah, M.R.M.; Radzi, A.M.; Izwan, S.; Azammi, A.M.N.; et al. Macro to nanoscale natural fiber composites for automotive components: Research, development, and application. In Biocomposite and Synthetic Composites for Automotive Applications; Sapuan, M.S., Ilyas, R.A., Eds.; Woodhead Publishing Series: Amsterdam, The Netherlands, 2020.

274. Inam, F.; Vo, T.; Jones, J.P.; Lee, X. Effect of carbon nanotube lengths on the mechanical properties of epoxy resin: An experimental study. J. Compos. Mater. 2013, 47, 2321-2330. [CrossRef]

275. Yang, Y.; Boom, R.; Irion, B.; van Heerden, D.J.; Kuiper, P.; de Wit, H. Recycling of composite materials. Chem. Eng. Process. Process. Intensif. 2012, 51, 53-68. [CrossRef]

276. Njuguna, J.; Silva, F.; Sachse, S. Nanocomposites for vehicle structural applications. In Nanofibers Production, Properties and Functional Applications; Lin, T., Ed.; InTech: Rijeka, Crotia, 2011; pp. 401-434.

277. Jin, M.; Feng, X.; Feng, L.; Sun, T.; Zhai, J.; Li, T.; Jiang, L. Superhydrophobic Aligned Polystyrene Nanotube Films with High Adhesive Force. Adv. Mater. 2005, 17, 1977-1981. [CrossRef]

278. Lee, S.K.; Bai, B.C.; Im, J.S.; In, S.J.; Lee, Y.-S. Flame retardant epoxy complex produced by addition of montmorillonite and carbon nanotube. J. Ind. Eng. Chem. 2010, 16, 891-895. [CrossRef]

279. Jia, X.; Wei, F. Advances in Production and Applications of Carbon Nanotubes. Top. Curr. Chem. 2017, 375, 18. [CrossRef] [PubMed]

280. Kong, J.; Franklin, N.R.; Zhou, C.; Chapline, M.G.; Peng, S.; Cho, K.; Dai, H. Nanotube molecular wires as chemical sensors. Science 2000, 287, 622-625. [CrossRef]

281. Sattari, S.; Reyhani, A.; Khanlari, M.R.; Khabazian, M.; Heydari, H. Synthesize of polyaniline-multi walled carbon nanotubes composite on the glass and silicon substrates and methane gas sensing behavior of them at room temperature. J. Ind. Eng. Chem. 2014, 20, 1761-1764. [CrossRef] 
282. Rajabi, Z.; Moghadassi, A.R.; Hosseini, S.M.; Mohammadi, M. Preparation and characterization of polyvinylchloride based mixed matrix membrane filled with multi walled carbon nano tubes for carbon dioxide separation. J. Ind. Eng. Chem. 2013, 19, 347-352. [CrossRef]

283. Khan, A.; Khan, A.A.P.; Asiri, A.M.; Rub, M.A.; Azum, N.; Khan, S.B.; Marwani, H.M. Applied poly(2-methoxy aniline) $\mathrm{Sn}(\mathrm{II})$ silicate carbon nanotubes composite: Synthesis, characterization, structure-property relationships and applications. J. Ind. Eng. Chem. 2014, 20, 2301-2309. [CrossRef]

284. Gomès, S.; Trannoy, N.; Grossel, P. DC thermal microscopy: Study of the thermal exchange between a probe and a sample. Meas. Sci. Technol. 1999, 10, 805-811. [CrossRef]

285. Rafique, I.; Kausar, A.; Anwar, Z.; Muhammad, B. Exploration of Epoxy Resins, Hardening Systems, and Epoxy/Carbon Nanotube Composite Designed for High Performance Materials: A Review. Polym. Plast. Technol. Eng. 2016, 55, 312-333. [CrossRef]

286. Thostenson, E.T.; Chou, T.-W. Processing-structure-multi-functional property relationship in carbon nanotube/epoxy composites. Carbon N. Y. 2006, 44, 3022-3029. [CrossRef]

287. Johari, A.N.; Ishak, M.R.; Leman, Z.; Yusoff, M.Z.M.; Asyraf, M.R.M.; Ashraf, W.; Sharaf, H.K. Fabrication and cut-in speed enhancement of savonius vertical axis wind turbine (SVAWT) with hinged blade using fiberglass composites. In Proceedings of the Seminar Enau Kebangsaan, Bahau, Negeri Sembilan, Malaysia, 1 April 2019; pp. 978-983.

288. Mishnaevsky, L.; Branner, K.; Petersen, H.N.; Beauson, J.; McGugan, M.; Sørensen, B.F. Materials for wind turbine blades: An overview. Materials 2017, 10, 1285. [CrossRef]

289. Loos, M.R.; Schulte, K. Is it worth the effort to reinforce polymers with carbon nanotubes? Macromol. Theory Simul. 2011, 20, 350-362. [CrossRef]

290. Böger, L.; Sumfleth, J.; Hedemann, H.; Schulte, K. Improvement of fatigue life by incorporation of nanoparticles in glass fibre reinforced epoxy. Compos. Part A Appl. Sci. Manuf. 2010, 41, 1419-1424. [CrossRef]

291. Ali, S.S.S.; Razman, M.R.; Awang, A. The estimation and relationship of domestic electricity consumption and appliances ownership in Malaysia's intermediate city. Int. J. Energy Econ. Policy 2020, 10, 116-122. [CrossRef]

292. Ali, S.S.S.; Razman, M.R.; Awang, A. The nexus of population, GDP growth, electricity generation, electricity consumption and carbon emissions output in Malaysia. Int. J. Energy Econ. Policy 2020, 10, 84-89. [CrossRef]

293. Zainuddin, S.; Mascunra Amir, A.; Kibi, Y.R.; Khairil, M.; Zarina Syed Zakaria, S.; Rizal Razman, M. Social engineering model of natural resources management of Palu City. J. Eng. Appl. Sci. 2019, 14, 275-279. [CrossRef]

294. Ali, M.E.; Das, R.; Maamor, A.; Hamid, S.B.A. Multifunctional carbon nanotubes (CNTs): A new dimension in environmental remediation. Adv. Mater. Res. 2014, 832, 328-332. [CrossRef]

295. Agnihotri, S.; Mota, J.P.B.; Rostam-Abadi, M.; Rood, M.J. Structural characterization of single-walled carbon nanotube bundles by experiment and molecular simulation. Langmuir 2005, 21, 896-904. [CrossRef]

296. Upadhyayula, V.K.K.; Deng, S.; Mitchell, M.C.; Smith, G.B. Application of carbon nanotube technology for removal of contaminants in drinking water: A review. Sci. Total Environ. 2009, 408, 1-13. [CrossRef] [PubMed]

297. Yan, H.; Yang, X.; Chen, J.; Yin, C.; Xiao, C.; Chen, H. Synergistic removal of aniline by carbon nanotubes and the enzymes of Delftia sp. XYJ6. J. Environ. Sci. 2011, 23, 1165-1170. [CrossRef]

298. Zhai, R.; Zhang, B.; Wan, Y.; Li, C.; Wang, J.; Liu, J. Chitosan-halloysite hybrid-nanotubes: Horseradish peroxidase immobilization and applications in phenol removal. Chem. Eng. J. 2013, 214, 304-309. [CrossRef]

299. Ihsanullah, A.A.; Al-Amer, A.M.; Laoui, T.; Al-Marri, M.J.; Nasser, M.S.; Khraisheh, M.; Atieh, M.A. Heavy metal removal from aqueous solution by advanced carbon nanotubes: Critical review of adsorption applications. Sep. Purif. Technol. 2016, 157, 141-161. [CrossRef]

300. Carbon Nanotubes (CNT) Market by Type (Single, Multi Walled), Method (Chemical Vapor Deposition, Catalytic Chemical Vapor Deposition, High Pressure Carbon Monoxide), Application (Electronics, Chemical, Batteries, Energy, Medical)—Global Forecast to 2023. Available online: https:/ / www.marketsandmarkets.com/Market-Reports/carbon-nanotubes-139.html (accessed on 21 March 2021).

301. Da Luz, F.S.; Garcia Filho, F.D.C.; Del-Rio, M.T.G.; Nascimento, L.F.C.; Pinheiro, W.A.; Monteiro, S.N. Graphene-incorporated natural fiber polymer composites: A first overview. Polymers 2020, 12, 1601. [CrossRef] [PubMed] 